\title{
Effects of acetaminophen on estrogen-responsive alkaline phosphatase in Ishikawa endometrial cancer cells
}

Janet A. Dowdy

West Virginia University

Follow this and additional works at: https://researchrepository.wvu.edu/etd

\section{Recommended Citation}

Dowdy, Janet A., "Effects of acetaminophen on estrogen-responsive alkaline phosphatase in Ishikawa endometrial cancer cells" (2000). Graduate Theses, Dissertations, and Problem Reports. 1161. https://researchrepository.wvu.edu/etd/1161

This Thesis is protected by copyright and/or related rights. It has been brought to you by the The Research Repository @ WVU with permission from the rights-holder(s). You are free to use this Thesis in any way that is permitted by the copyright and related rights legislation that applies to your use. For other uses you must obtain permission from the rights-holder(s) directly, unless additional rights are indicated by a Creative Commons license in the record and/ or on the work itself. This Thesis has been accepted for inclusion in WVU Graduate Theses, Dissertations, and Problem Reports collection by an authorized administrator of The Research Repository @ WVU. For more information, please contact researchrepository@mail.wvu.edu. 


\title{
Effects of Acetaminophen on Estrogen-Responsive
}

Alkaline Phosphatase in Ishikawa Endometrial Cancer Cells

Janet A. Dowdy

Thesis submitted to the

School of Medicine

At West Virginia University

In partial fulfillment of the requirements

For the degree of

Master of Science

in

Pharmacology and Toxicology

\author{
Committee Chair: \\ Michael R. Miller, Ph.D. \\ Committee Members: \\ Robert E. Stitzel, Ph.D. \\ Mark J. Reasor, Ph.D
}

Department of Pharmacology and Toxicology

Morgantown, West Virginia

2000

Key Words: acetaminophen, alkaline phosphatase, estradiol, estrogen receptors, Ishikawa cells 


\begin{abstract}
Effects of Acetaminophen on Estrogen-Responsive Alkaline Phosphatase Activity in Ishikawa Endometrial Cancer Cells
\end{abstract}

\title{
Janet A. Dowdy
}

This study examines the effect of acetaminophen (APAP) on the estrogen-responsive gene alkaline phosphatase in Ishikawa endometrial cancer cells. Basal levels of alkaline phosphatase activity were significantly inhibited in cells treated with $0.03,0.1,0.3$ and $1 \mathrm{mM}$ APAP compared to control. Alkaline phosphatase activity induced with $1 \mathrm{nM}$ estradiol was significantly inhibited in a concentration dependent manner by $0.0 .1,0.3$ and $1 \mathrm{mM}$ APAP. APAP did not directly inhibit the activity of alkaline phosphatase at any of the concentrations tested. Increasing estradiol concentrations $(0.01,0.1$ and $1 \mathrm{nM})$ did not alter the level of inhibition of alkaline phosphatase activity by $0.1,0.3$ or $1 \mathrm{mM}$ APAP. This is in agreement with other studies, which have concluded that APAP does not compete with estradiol for binding at the estrogen receptor (Harnagea-Theophilus $\mathrm{s}_{\mathrm{a}}$ et al., 1999; Isenhower et al., 1986; Miller et al., 1999). Protein concentrations were significantly decreased in Ishikawa cells with 0.3 and $1 \mathrm{mM}$ APAP alone or in the presence of $0.01,0.1$ to $1 \mathrm{nM}$ estradiol. Inhibition of alkaline phosphatase activity by high levels $(0.3$ and $1 \mathrm{mM})$ of APAP may be in part due to toxic effects of APAP as determined by LDH release. Fluorescent microscopy using calcein staining techniques show that Ishikawa cells treated with $1 \mathrm{nM}$ E2 $+0.3 \mathrm{mM}$ APAP are visibility misshapen; cells treated with $1 \mathrm{nM}$ E2 $+1 \mathrm{mM}$ APAP are no longer attached to the plate indicating toxicity. The final part of this study looked at the interaction between antiestrogen-4-hydroxy tamoxifen (OHT) and APAP on alkaline phosphatase activity in Ishikawa cells. While OHT inhibited alkaline phosphatase activity $\sim 50$ percent in estradiol-induced cells, addition of $0.03-1 \mathrm{mM}$ APAP increased inhibition significantly in a concentration dependent manner. Results of this study indicate that APAP decreases estrogen-responsive alkaline phosphatase activity in Ishikawa cells in vitro, and that this inhibition is not attributed to direct inhibition of enzyme activity. 
Dedication

\author{
To \\ Candace and Cathlene
}




\section{Acknowledgements}

I would like to graciously acknowledge the following people who made my graduate career a successful and memorable one.

First I would like to extend my gratitude to my advisor and committee chairman Dr. Miller for his professional advice and guidance while supporting my decisions and progress with constant enthusiasm even during the lowest point of my contamination catastrophe. Thank you especially for imparting valuable writing and oral presentation skills such that I can present my research with confidence. To my committee members Dr. Reasor and Dr. Stitzel, thank you for your guidance, suggestions and constructive criticisms, which served to refine my skills as a scientist. To my committee as a whole, your dedication to help me achieve my goals is greatly appreciated.

To the members of my lab group Samantha Gadd, Stacey Rhodes and Dr. Stamm, thank you for discussion, suggestion and instruction in the lab. Sam, thank you for sharing everything you know about cell tissue cultures. Dr. Stamm, thank you for passing the lab secrets regarding the mysterious ways of western blots.

To the faculty, staff and students of the Department of Pharmacology and Toxicology I am proud to be a graduate of this outstanding department. In addition to an excellent education, I will always carry fond memories of my time here as part of a wonderfully dedicated, supportive and professional group of people. In particular, Zara Melkoumian, Tripp Griffin, Qun Zhao, Rich Johnston, Michael Taylor thank you for your comradery and I wish you all the best in your future endeavors. To my fellow student toxicologists, remember that no matter what they try to tell you, Toxicology is pharmacology, just at a higher dose.

To the people at NIOSH where I spent my first year and half of research, Dr. Huffman and Delores Judy, thank you for making my time in your lab a pleasant one. To Lyndell Millecchia the microscopy expert, thank you for all your help with the beautiful fluorescent photographs included within my thesis. To Dr. Murono, thank you for the generous gift of ICI 182,780 for my project. To Dr. Fedan, Rich and Samy, thank you for support and understanding in the final weeks while I struggled to complete my thesis and defense.

To my family, especially my parents Lucille and James and my sister Lucy, thank you for unwavering support of my decision to pursue a graduate education. To Raymond, for your encouragement and willingness to relocate our family to Morgantown without hesitation, a heartfelt thank you. To my daughters Candace and Cathlene, for enduring life with a graduate student mom, I love you dearly.

To the many friends that I have been blessed with since my arrival to Morgantown, thank you for your caring and support. To Betty, thank you for reaching out, as well as taking time to recognize and celebrate my accomplishments with me. To Robert, thank you for your endless interest, encouragement and confidence in me. 
Table of Contents

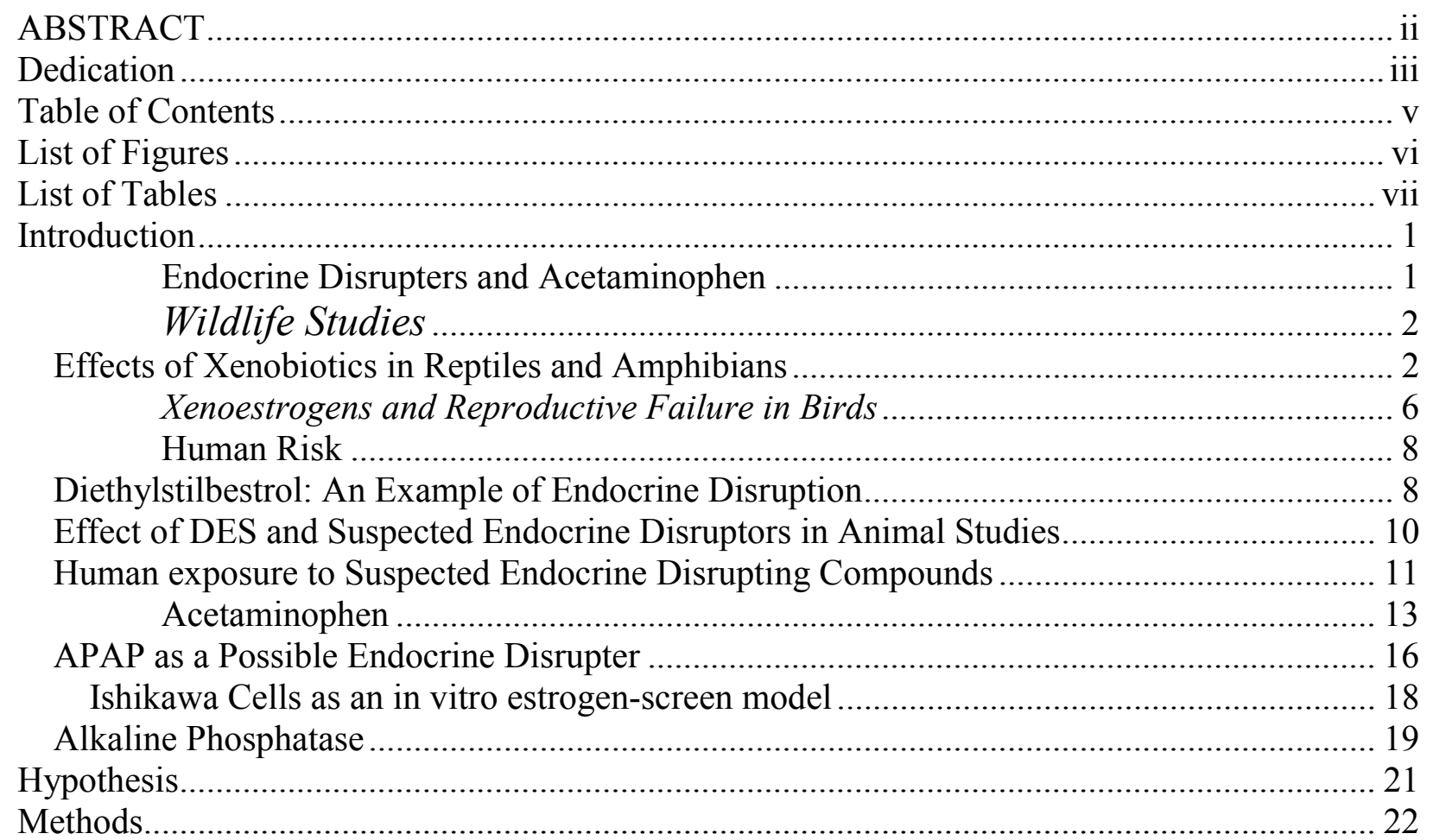

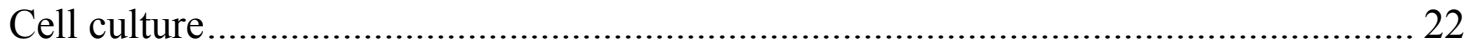

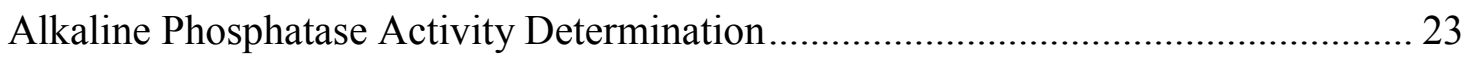

Induction of Alkaline Phosphatase: ...................................................................... 24

Total Cellular Protein Determination by Fluorescamine .................................... 25

Lactate Dehydrogenase Cytotoxicity Assay .................................................. 26

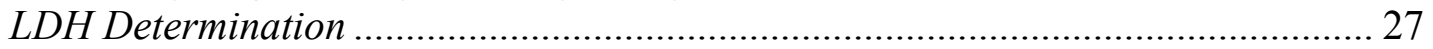

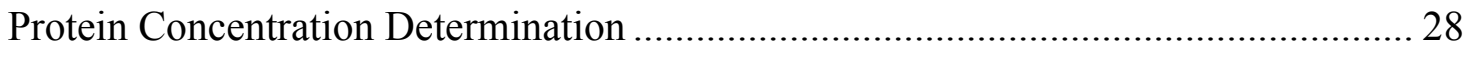

Effect of Acetaminophen (APAP) on Alkaline Phosphatase Enzyme Activity .......... 29

Fluorescence Microscopy: Calcein Staining..................................................... 29

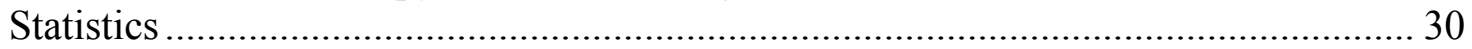

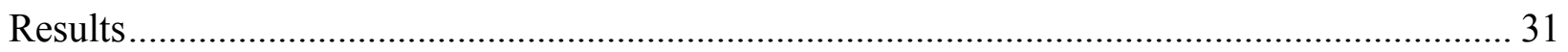

Estradiol Induction of Alkaline Phosphatase in Ishikawa Cells .......................... 31

Acetaminophen Inhibits Basal Alkaline Phosphatase activity in Ishikawa Cells........ 32

Acetaminophen Inhibits Estradiol-Induced Alkaline Phosphatase ........................... 32

Lactate Dehydrogenase Cytotoxicity Assay ................................................... 33

Alkaline Phosphatase Enzyme Is Not Directly Inhibited By Acetaminophen ............ 35

Effects of Varying Concentrations of $\mathrm{E}_{2}$ and APAP on Alkaline Phosphatase Activity

and Protein Concentration................................................................................. 36

APAP Amplifies Antiestrogen Effects in Ishikawa Cells..................................... 38

Fluorescent Microscopy ............................................................................. 40



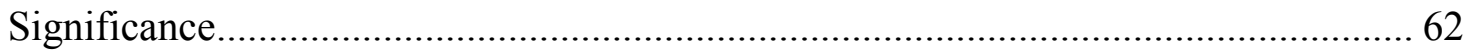

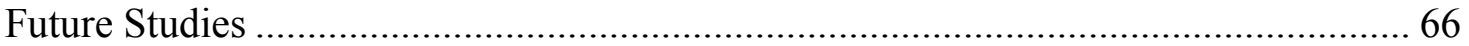

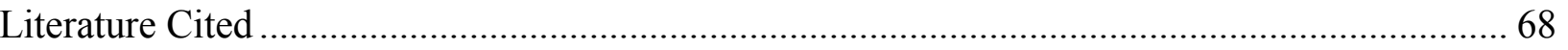




\section{List of Figures}

1. Structure of estradiol, diethylstilbestrol and suspected xenoestrogens ...............4

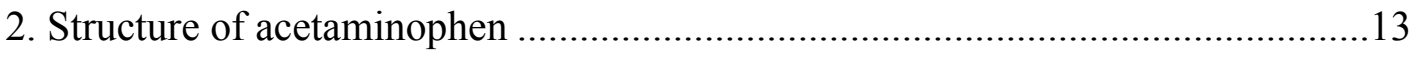

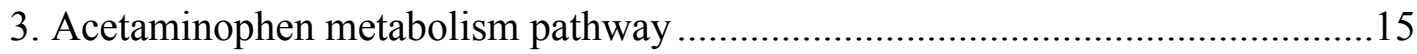



5. Estradiol induces alkaline phosphatase activity........................................41

6. Estradiol increases total cellular protein concentrations..................................42

7. Acetaminophen inhibits basal alkaline phosphatase activity ...........................43

8. Acetaminophen decreases total cellular protein...........................................44

9. Acetaminophen inhibits $E_{2}$-induced alkaline phosphatase activity ....................45

10. Acetaminophen decreases total cellular protein in $\mathrm{E}_{2}$-treated cells ...................46

11. Tamoxifen inhibits $E_{2}$-induced alkaline phosphatase activity .........................47

12. Tamoxifen decreases total cellular protein in $\mathrm{E}_{2}$-treated cells ..........................48

13. Anti-estrogen ICI 182,780 inhibits $E_{2}$-induced alkaline phosphatase ...............49

14. Anti-estrogen ICI 182,780 decreases total protein in $\mathrm{E}_{2}$-treated cells ................50

15. Acetaminophen amplifies tamoxifen inhibition of $E_{2}$-induced alkaline

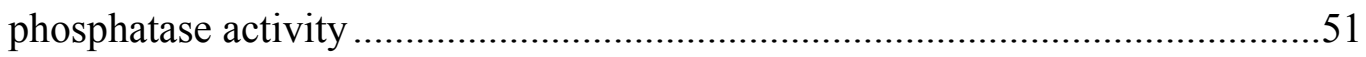

16. Acetaminophen decreases total protein in $\mathrm{E}_{2}$-tamoxifen treated cells ................52

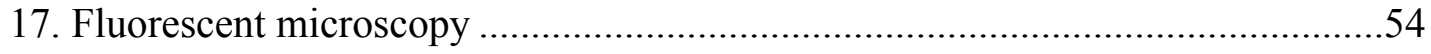

18. Estrogen receptor mediated gene transcription: alkaline phosphatase................66

19. Aryl hydrocarbon receptor mediated gene transcription ...............................67 


\section{List of Tables}

1. Effect of Acetaminophen on Lactate Dehydrogenase Release...............................35

2. Effect of Acetaminophen on Alkaline Phosphatase Enzyme Activity...................36

3. Changes in Alkaline Phosphatase Activity and Protein Concentrations with varying

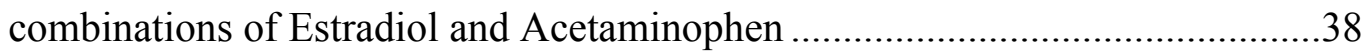




\section{Introduction}

\section{Endocrine Disrupters and Acetaminophen}

Endocrine Disrupters (EDs) are exogenous agents that interfere with the synthesis, secretion, transport, binding or elimination of natural hormones in the body. Although most known EDs, such as 1,1,1-trichloro-2,2-bis(p-chlorophenyl) ethane (DDT), have estrogen-like activity, it is possible for EDs to possess antagonist activity or to cross talk between different endocrine pathways. The significance of alterations to endocrine processes includes disruption in hormone-mediated functions such as maintenance of homeostasis, reproduction, development, and/or behavior. Wildlife studies have shown the impact of EDs, such as DDT and polychlorinated biphenyls (PCBs), upon animal populations. Effects of these environmental EDs upon the human population are inconclusive, yet the worldwide increases in reproductive organ

cancers (Brasso et al., 1999; Giwercman et al., 1993; Hill et al., 1983; Murphy et al., 1999; Sant 1999 et al., Wingo et al., 1998), ectopic pregnancies (Rajkhowa et al., 2000), male urogential malformations (Weidner et al., 1998; Paulozzi et al., 1997), and decreased sperm count (Swan et al., 1999) cause concern that EDs may be impacting human health.

Acetaminophen (APAP), a commonly used analgesic/antipyretic, is currently being investigated as a possible xenoestrogen. APAP contains a $p$-hydroxyl group and lipophylic conjugated six-member ring structure like estradiol (Cunningham et al., 1997). In vitro studies have shown that acetaminophen has the ability to induce estrogen-mediated DNA synthesis and cell proliferation in estrogen receptor positive $(\mathrm{ER}+)$ breast cancers cells (Harnagea-Theophilus et al., 1998) and inhibits estradiol-induced vitellogenin production in trout liver cells (Miller et al., 1999). Although no estrogenic activity was observed in uterotropic bioassays (HarnageaTheophilus b et al., 1999, Isenhower et al., 1986), animal studies have shown that APAP reduced 
the number of litters per breeding pair, increased abnormal sperm counts and increased testicular atrophy in mice (Boyd et al., 1970, Reel et al., 1992). Even more significant are case studies indicating that APAP has endocrine altering effects in the human population such as lowering basal hormone levels in women $\left(\mathrm{Cramer}_{\mathrm{b}}\right.$ et al., 1998) and reducing the risk of ovarian cancer (Cramer ${ }_{\mathrm{a}}$ et al., 1998). In combination, these studies suggest that APAP is impacting endocrine function not only in in vitro and animal studies but also within the human population taking this drug.

\section{Wildlife Studies}

Environmental contaminants have posed a threat to wildlife since the beginning of the industrial age. The theory that environmental pollutants, such as organochlorine pesticides and industrial waste, could have endocrine disrupting effects is a newer concern. The 1979 National Institute of Health's "Estrogens in the Environment" symposium was the beginning of investigation into the endocrine disrupting potential of man-made chemicals being released into the environment (Guillete ${ }_{\mathrm{b}}$ et al., 1995; McLachlan et al., 1992)(Fig.1). The connection between wildlife health effects and environmental exposure to endocrine disrupting chemicals has been well established. In addition, laboratory studies have shown that xenobiotics with estrogenic activity significantly alter both embryonic development and adult reproductive function in different animal models. The significance of these studies must be addressed to fully understand the impact that xenobiotic exposure could have upon the human population.

\section{Effects of Xenobiotics in Reptiles and Amphibians}

Aquatic animals are exposed to chemical pollutants dermally, orally, and through the food chain. While most environmental contamination occurs due to agricultural and urban use of pesticides, industrial waste is also a significant source and can pose a serious threat to wildlife. 
One such example is the chemical spill by the Tower Chemical Company at Lake Apopka, Florida in 1980 (Semenza et al., 1997). That extensive chemical spill, which consisted mostly of difocal and DDT, led to registration of the lake as an EPA Superfund contamination site (Guillette et al., 1994). By 1994 the American alligator (Alligator mississippiensis) population at Lake Apopka had fallen to one tenth of its original number since 1970 and elevated levels of p,p'-DDE were found in the alligator eggs collected from the lake between 1984-85 (Guillette et al., 1994; Jennings et al., 1998, Woodward et al., 1989).

While poor egg viability could not be directly correlated to the elevated organochlorine levels (Heinz et al., 1991), the observed concentrations (5.8ppm wet weight) were known to cause adverse effects in avian embryos (Cooper et al., 1991). Juvenile alligators obtained as eggs from Lake Apopka had significantly increased serum levels of p,p'-DDE, dieldrin, endrin, mirex, oxychlordane, DDTs, and PCBs compared to juveniles from uncontaminated Florida lakes

(Guillette et al., 1999). However, the most disturbing aspect of these studies indicated changes in gonad morphology in both male and females alligators as well as changes in plasma sex steroid levels. Guillette reported that female alligators had plasma estrogen levels two times higher than normal along with the abnormal formation of ovaries. Male alligators had plasma testosterone levels three times lower than normal, malformed testes, and decreased phallus size (Guillette et al., 1996). 
Fig.1. Structures of estradiol, DES and suspected xenoestrogens



DDT

$$
\text { PCBs }
$$<smiles>[X]c1c([X])c([X])c(-c2c([X])c([X])c([X])c([X])c2[X])c([X])c1[X]</smiles><smiles>Clc1cc2c(cc1Cl)Oc1cc(Cl)c(Cl)cc1O2</smiles>

$\mathrm{X}=\mathrm{H}$ or $\mathrm{Cl}$

Bisphenol A

DES<smiles>CC(C)(c1ccc(O)cc1)c1ccc(O)cc1</smiles><smiles>CCC(c1ccc(O)cc1)C(CC)c1ccc(O)cc1</smiles> 
In vitro studies examining steroidogenic activity of gonadal tissue from juvenile alligators showed changed in estradiol synthesis. Estrogen synthesis was increased in males and decreased in females; however, no significant differences in testosterone production were observed. Differences noted between steroid levels in vivo and in vitro studies may be explained by steroid synthesis and degradation processes that occur in the whole animal but not in in vitro studies (Guillette e $_{\mathrm{a}}$ et al., 1995). These studies support Guillette's theory that chemicals spilled into Lake Apopka in 1980 have modified both reproductive and endocrine development permanently in resident alligators in ovo.

Receptor binding studies have shown that some environmental chemicals possess the ability to bind alligator estrogen (aER) and alligator progesterone (aPR) receptors, which are present in the alligator oviduct (Vonier et al., 1997). p,p'-DDD and trans-nonaclor, both found in Lake Apopka following the chemical spill, interacted with aER while chlordane and toxaphene did not. However, when combined, these chemicals decreased $\left[{ }^{3} \mathrm{H}\right]$-estradiol binding to aER in a greater than additive manner (Vonier et al., 1996). Chlordane, dieldren and toxaphene, which possess little appreciable estrogenic activity alone, in combination, act synergistically upon both alligator and human ER (Arnold et al., 1997).

Temperature-dependent sex determination studies (TDS) show that estrogen has the ability to reverse effects of a male-producing temperature in red-eared slider turtles (Trachemys scripta) (Crews et al., 1995, Willingham et al., 1999) and alligators (Alligator mississippiensis) (Bull et al., 1980; Guillette ${ }_{\mathrm{a}}$ et al., 1995). In TDS, each egg has the potential to develop into a male or female as determined by the incubation temperature present at critical developmental periods. Temperature acts as a trigger to begin the cascade of biochemical events that lead to sexual development of one gender or the other. Sex steroids play an interactive role in TSD; 
however, that role is not completely understood (Crews et al., 1995; Willingham et al., 1999). Xenobiotics suspected of being estrogenic were assayed at the concentrations found in alligator eggs from Lake Apopka. Those eggs incubated at a male-producing temperature with trans- and cis-Nonclor, aroclor 1242, p,p'-DDE or chlordane, alone or in combination, all produced significant sex reversal from male to female in red-eared slider turtles (Willingham et al., 1999). These studies demonstrate some of the more subtle effects that endocrine disrupting chemicals may have in reptile and amphibian populations.

\section{Xenoestrogens and Reproductive Failure in Birds}

Bioaccumulation of pesticides in predatory birds is a result of the widespread use, accumulation, and run-off of agricultural chemicals into aquatic environments. These contaminants are stored in the fatty tissue of fish and are consumed by predatory birds as well as other wildlife. Organochlorine pesticides, such as DDT, polychlorinated biphenols (PCBs), dioxins and dibenzofurans that have been identified as xenoestrogens, are linked to the reproductive failure in many avian species such as grebes (Rudd 1972), ospreys (Spitzer et al., 1978), falcons (Cade et al., 1971), bald eagles (Cromartie et al., 1975) and cormorants (Ludwig et al., 1996). Due to the lipophylic nature of these contaminants, they are not only stored in the fat tissues of exposed birds but are, in addition, passed to their offspring by deposition into the yolks of their eggs (Fry et al., 1981).

Avian embryos are especially sensitive to the effects of contaminants because they cannot be excreted and thus remain within the embryonic circulation throughout the incubation period. Metabolites of parent compounds can be more bioactive, as is the case of op'-DDT and methoxychlor, compounds which have been identified as weak xenoestrogens. Their hydroxylated metabolites have binding affinities almost equal to that of estradiol in estrogen 
receptor binding studies (Bulger et al., 1978). In addition, many organochlorine compounds are inducers of chick embryo liver mixed-function oxidases (Rodman et al., 1991) and could possibly compound the level of estrogenic exposure by increasing the rate of metabolic activation of the weaker parent compound.

Some effects of xenoestrogen exposure seen in birds are different than those found in mammals due to differences in steroid hormonal control during embryonic development. In contrast to mammals, male is the default sex in birds during sexual differentiation. Chick embryos differentiate from male to female only when estrogen is produced, resulting in the formation of the gonads into an ovary (Fry et al., 1995). Primordial germ cells (PGC), which migrate into the indifferent gonads during mid-gestation, by default end up in the seminiferous tubules in males (Romanoff et al., 1960). Estradiol induces development of the ovarian structure, regression of the right cortex and localization of PCG into the left cortex, which develops into an ovary (Fry et al., 1995). Gull eggs injected with op'-DDT or methoxychlor mimicked effects seen with estradiol or DES and developed abnormalities in both male and female embryos. Male embryos showed abnormal development of an oviduct or ovarian type tissue, and PGCs became localized in this ovarian-like tissue as well as in the seminiferous tubules. The right oviduct only partially regressed in females (Boss et al., 1947; Fry et al., 1987; Romanoff et al., 1960). DDT feminization has been associated with the inability of male gulls to breed and the high ratio of female to male gulls on Santa Barbara Island in Southern California (Fry et al., 1981).

However, the most dramatic effect of DDT is eggshell thinning in exposed birds. While the inhibition of $\mathrm{Ca}^{2+}$-ATPase activity by DDT is well known, DDT also strongly inhibits the binding of progesterone and testosterone to their respective receptors located in the eggshell mucosal gland (Lunholm et al., 1991). In addition, DDT-induced eggshell thinning may be due 
to an estrogenic effect. Hens exposed to estrogen as chicks produced defective, thin, or soft eggs in adulthood (Greenwood et al., 1938). Studies of Japanese quail exposed to DDT during embryonic development demonstrated not only increased eggshell malformations as adult hens, but also had long-term effects upon their reproductive behaviors (Bryan et al., 1989).

\section{Human Risk}

While the health effects of endocrine disruption upon wildlife have been well documented, the human risk is not as clearly defined. Human pathologies and disorders that may be related to EDs include increased incidence of: breast and female reproductive tract cancers (Hill et al., 1983; Sant et al., 1999; Wingo et al., 1998); prostate cancers (Brasso et al., 1999; Giwercman et al., 1993; Murphy et al., 1999); ectopic pregnancies (Rajkhowa et al., 2000); cryptorchidism and hypospadius (Paulozzi et al., 1997; Weidner et al., 1998); and a 50\% decrease in sperm counts within the last 50 years (Swan et al., 1999). These trends in reproductive disorders and disease mimic the effects seen in both human diethylstilbestrol (DES) exposure and in studies of animals exposed to endocrine disrupting compounds.

\section{Diethylstilbestrol: An Example of Endocrine Disruption}

Diethylstilbestrol (DES) is an estrogenic drug that was used therapeutically from 19401970 by approximately 6 million women worldwide to prevent habitual or spontaneous abortion. Adverse reactions to DES only appeared 12-15 years after exposure in the children of those women who took the drug during pregnancy. These side-effects range from infertility and reproductive tract anomalies to increased risk of rare cancers, and continue to appear in third generations (Dukes, 1996). In 1987, the Registry for Research on Hormonal Transplacental 
Carcinogenesis reported that $60 \%$ of vaginal or cervical clear-cell carcinoma documented cases were in women who had been exposed to DES in utero. Exposed female children have a 30\% probability of developing cervical vaginal adenosis during adolescence, which can develop into clear-cell adenocarcinoma. In addition to reproductive disorders, these women also have a 50\% greater chance of developing autoimmune disease (Dukes, 1996). Exposed male children are at risk for a variety of reproductive disorders including cryptochordism, urethral abnormalities, epididymal cysts, testicular hypoplasia, decreased semen quality, and a doubled risk of developing testicular cancer (Toppari et al., 1996). DES case studies represent the only known data on the catastrophic effects of an estrogenic compound upon the human population. 


\section{Effect of DES and Suspected Endocrine Disruptors in Animal Studies}

There have been extensive studies showing that prenatal DES exposure in rodents, at concentrations equivalent to the human therapeutic dose, produce similar effects upon fertility, reproductive tract development and function. Female mice exposed in utero had a dosedependent decrease in fertility, vaginal adenocarcinoma, cervical enlargement, cystic endometrial, ovarian tumors, and congenital malformations (McLachlan et al., 1980; Newbold et al., 1995). These reproductive tract lesions and fertility problems are very similar to those reported clinically in DES-exposed women. In rats, male offspring had a 5\% risk of developing a rare testis cancer and a $92 \%$ risk of having retained testis or cryptochordism (Newbold et al., 1995). As in the human exposure-effect, these reproductive anomalies are not always apparent in the offspring at birth. Male hamsters exposed to DES prenatally appeared normal at pubertal age, but as adults exhibited multiple lesions in reproductive tracts, spermatogenesis, cryptochordism and testicular tumors (Khan et al., 1998).

Prenatal exposure to compounds suspected of causing endocrine disruptive activity, such as PCBs and phytoestrogens, have been shown to impact both reproductive system development and sexual behavior in male rats in the same manner as DES. Prenatal exposure to 4-octylphenol (OP), butyl benzyl phthalate (BBP), or Bis-phenol A all cause decreases in testicular size and sperm count (Sharpe et al., 1995; vom Saal et al., 1998). Phytoestrogens cause alterations in the development of the CNS-gonadal axis and male sexual behavior (Santti et al., 1998). In utero and lactational exposure to 2,3,7,8-tetrachlorodibenzo-p-dioxin (TCCD) decreases plasma testosterone levels at birth and causes a permanent decrease in testicular size (Mably et al., 1992). Chronic OP exposure of the adult animal decreases serum LH, FSH and testosterone (Blake et al., 1997), shrinkage of reproductive organs, and increases in sperm deformities 
(Boockfor et al., 1997). Benzene-based dyes, antiandrogenic fungicides, TCCD and PCB 169 exposure have all been correlated with abnormal rodent sex differentiation (Gray et al., 1999). Aroclor, as well as the chlorobiphenyl (CB) congeners CB47 and CB153, has shown estrogenic activity in female rat uterotropic studies (Soontornchat et al., 1994).

\section{Human exposure to Suspected Endocrine Disrupting Compounds}

Evidence of endocrine-disrupting effects upon the human population is complex, controversial and very limited. However, there are several studies examining the effects of PCBs upon human development and the relationship between organochlorines and development of breast cancer in women.

Prenatal PCB exposure through maternal consumption of contaminated fish from the Upper Great Lake Region increases the risk of lower birth weight, smaller head circumference (Fein et al., 1984), and decreased reflex and autonomic processing on the Neonatal Behavior Assessment Scale (NBAS) in the newborn (Lonky et al., 1996). Postnatal exposure through lactation most significantly decreased physical activity levels (Jacobson et al., 1989). A follow up study of prenatally exposed 4-year-olds indicates that these children continue to have poor cognitive function in terms of short-term memory and processing speed (Jacobson et al., 1993). While estrogen receptor subtypes $\alpha$ and $\beta$ are both expressed in various regions of the human brain (Beyer et al., 1999), their role in development of the central nervous system (CNS) is not completely understood. It is becoming more apparent that estrogen is important not only in sexual differentiation and reproductive neuroendocrine function, but also in neuron growth and differentiation (Toran-Allerand et al., 1999). Whether or not PCBs act with estrogenic activity upon the CNS during human fet al. development has yet to be determined. 
Less conclusive studies have suggested that EDs may be responsible for higher male:female sex ratio of birth defects (urigenital / cardiovasculature / CNS) amongst pesticide appliers in Minnesota (Garry et al., 1996); significant alteration in the male:female ratio in occupational carbon setters (Milham et al., 1993), and permanent changes in sperm production in farm sprayers exposed to 2,4-dichlorophenoxyacetic acid (2,4-D) (Lerda et al., 1991).

Environmental organochlorines, such as PCBs and DDE, are being investigated as possible risk factors in breast cancer of women. Case studies show that the cancerous breast tissue obtained from women has a $62 \%$ higher concentration of p,p'-DD and $25 \%$ increase in PCB118 (Guttes et al., 1998) compared to normal healthy tissue. Another study found that serum samples taken near the time of breast cancer diagnosis showed a positive correlation between the serum levels of PCB118, PCB 138, hexachlorobenzene, dieldrin and breast cancer incidence in women (Dorgan et al., 1999; Guttes et al., 1998; Hoyer et al., 1998). The New York University Women's Health Study from 1985-1991 indicated that DDE increased breast cancer risk 4-fold while PCBs increased risk less than two-fold (Wolff et al., 1993). Other studies have found no correlation between serum organochlorine levels and incidence of breast cancer in women (Helzlsouer et al., 1999; Krieger et al., 1994). The contribution of organochlorines to the risk of the development of breast cancer is still controversial. However, the fact remains that organochlorines are present in significantly higher concentrations in the adipose tissue and serum of women in high-risk locations such as Long Island, New York (Stellman et al., 1998). Because of their prevalence in the environment, further investigation is necessary to discern the possible contribution of xenoestrogens to the development of breast cancer in women. 


\section{Acetaminophen}

Acetaminophen (APAP) is a widely used analgesic and antipyretic found in more than 850 over-the-counter and prescription formulations (Prescott et al., 1996) (Fig.2.). APAP exerts its analgesic and antipyretic activity through selective inhibition of the cyclo-oxygenase isoenzyme in the central nervous system. APAP is a weak inhibitor of peripheral cyclooxygenase and possesses only very weak anti-inflammatory effects (Welch and Martin 1995, Rang and Dale 1997).

Fig.2. Structure of Acetaminophen

\section{ACETAMINOPHEN}

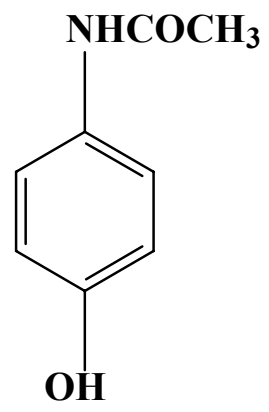

Acetaminophen metabolism (Fig.2.) occurs primarily in the liver where it is conjugated with glucuronide or sulfate and then readily excreted in the urine (Jollow 1973, 1974). Mixedfunction-oxidases (MFOs) can also metabolize APAP forming a highly reactive metabolite, $\mathrm{N}$ acetyl-p-benzoquinone (NAPQI), which is inactivated by binding to intracellular glutathione (Dahlin 1984). However, if the glutathione stores within the cell become depleted, such as in the case of APAP overdose, NAPQI will covalently bind to cysteine residues of cellular proteins as a 3-(cystein-S-yl)-APAP adduct (Hinson 1980, Mitchell 1973). The depletion of glutathione due to certain disease states, such as liver cirrhosis or necrosis, also can lead to APAP toxicity due to NAPQI accumulation following chronic drug administration or high doses. In addition, individuals who may have induced P450 MFOs due to alcoholism or therapeutic drugs also run 
the risk of toxicity due to increased metabolic production of NAPQI (Welch and Martin 1995). The site and amount of relevant covalent binding has been directly correlated with the development of APAP toxicity in humans and laboratory animals (Hinson et al., 1995; Ray et al., 2000). Administration of N-acetylcysteine decreases NAPQI covalent binding and its associated toxicity (Piperno et al., 1976). 
Fig. 3. APAP Metabolism
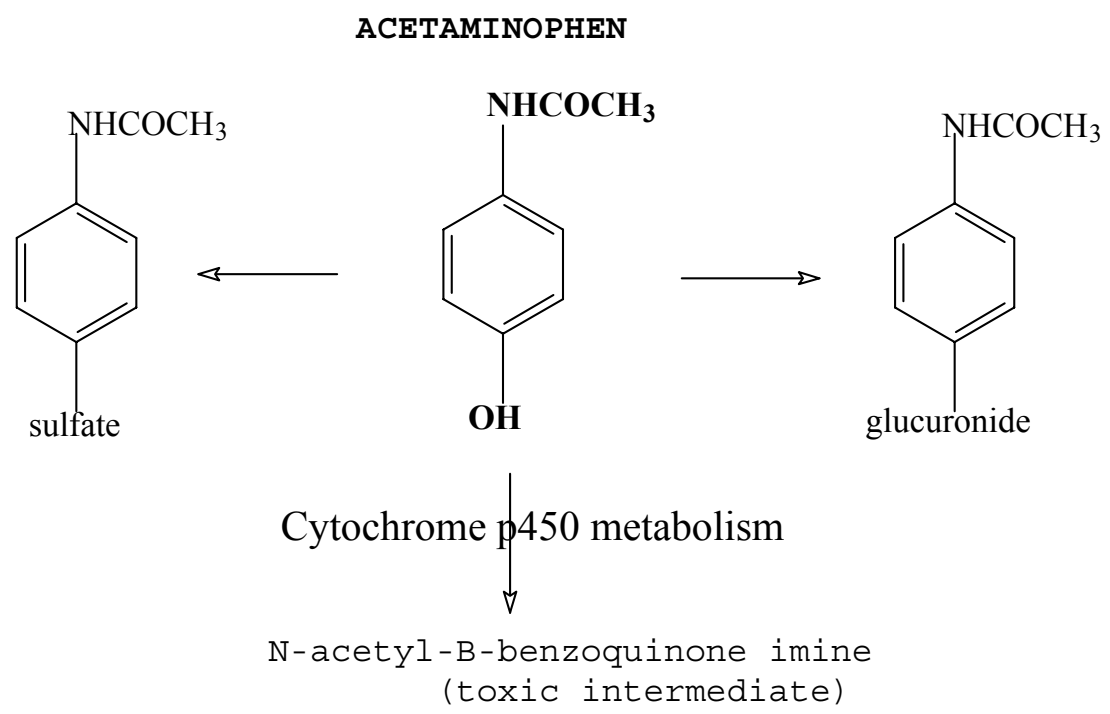

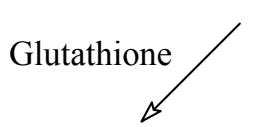<smiles>CCc1cc(NC(C)=O)ccc1O</smiles>

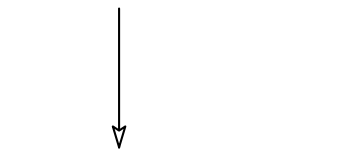

mercapturic acid
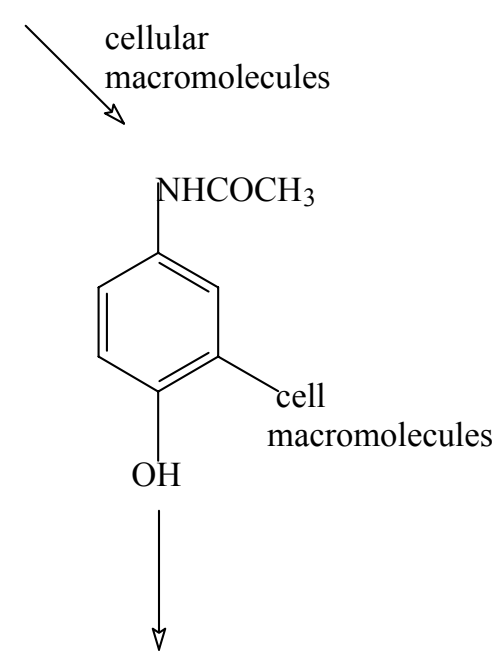

cell death

Acetaminophen has been shown to have various other effects upon cells in both in vitro and animal studies. At therapeutically relevant concentrations, APAP inhibits cell proliferation in HL-60 (Wiger et al., 1997), HepG2 (Dai et al., 1995), and V79 Chinese hamster cells (Holme et al., 1988); increases chromosomal breaks and inhibits DNA synthesis (Holme et al., 1988; Honglso et al., 1991); and down regulates c-myc and bcl-2 mRNA (Wiger et al., 1997). These 
effects do not appear to be a result of formation of the toxic metabolite NAPQI as HepG2 (Dai et al., 1995) and V79 cells (Kappers et al., 2000) do not express endogenous P450 activity.

In vitro studies in mouse and rat indicate that cytotoxic concentrations of APAP bind DNA, increase single strand breaks (SSBs), and interfere with DNA repair and synthesis (Honglso et al., 1994). In addition to hepatotoxicity (Tonge et al.,1998), high doses of APAP target mouse testis DNA synthesis resulting in decreased testicular weight, decreased number of spermatocytes, and deterioration in sperm chromatin structures (Wiger et al., 1995).

Genotoxic effects are also apparent as chromosomal aberration in humans. In two of the three studies conducted with human volunteers taking a maximum daily dose of APAP ( 3 x 1000 mg over 8-hours), there was a significantly higher frequency of chromatid breaks in peripheral lymphocytes 24 hours later (Hongslo et al., 1991).

\section{APAP as a Possible Endocrine Disrupter}

Recent studies have shown that APAP has the ability to alter estrogen responses in vitro in ER+ breast cancer cells. One study examined the effect of therapeutic concentrations of APAP upon estrogen-mediated DNA synthesis in ER+/PR+ and ER-/PR- breast cancer cells (HarnageaTheophilus et al., 1998). Proliferation was determined by [3H]-thymidine incorporation into DNA and percentage of cells in DNA synthesis (S) phase. While 0.1mM APAP was as effective as $3 \mathrm{nM}$ estradiol at promoting DNA synthesis in $\mathrm{ER}+/ \mathrm{PR}+$ cells, the combination of APAP and estradiol was not additive. In addition, cell proliferation was not induced by estradiol or APAP in ER-/PR- breast cancer cells.

Further studies examined the role of estrogen receptors (ER) in APAP-induced cell proliferation determined by $[3 \mathrm{H}]$-thymidine incorporation into DNA (Harnagea-Theophilus $\mathrm{s}_{\mathrm{a}}$ et 
al., 1999). APAP-induced cell proliferation in MCF7 and T47D $(\mathrm{ER}+/ \mathrm{PR}+)$ cells, but not in T47co (ER-/PR-) cells. Antiestrogens ICI 182,780 and 4'-hydroxytamoxifen, inhibited APAP induced proliferation in MCF7 and T47D $(\mathrm{ER}+/ \mathrm{PR}+)$ cells. Estrogen receptor binding studies were also performed in MCF7 (ER+/PR+) cells, and it was determined that APAP does not compete with estradiol for binding. The position of the -OH moiety on the benzene ring of APAP does appear to have an influence upon its ability to mimic estrogen-induced cell proliferation. Therapeutic plasma concentrations of APAP $(0.1 \mathrm{mM})$ induce varying amounts of breast cancer proliferation depending on the position of the $-\mathrm{OH}$ moiety $p->m->0$-acetaminophenol (HarnageaTheophilus $\mathrm{b}_{\mathrm{b}}$ et al., 1999). These studies concluded that APAP was acting upon estrogen receptormediated cell proliferation in a non-competitive manner with estradiol, and was inhibited by antiestrogens in $\mathrm{ER}+/ \mathrm{PR}+$, but not in (ER-/PR-) breast cancer cells. The position of the hydroxyl-group influences potency of this activity.

Acetaminophen's estrogenic activity has been investigated in another estrogen-dependent process, the production of vitellogenin in isolated trout liver cells. Vitellogenin production is an absolutely estrogen-dependent process in trout liver cells. APAP caused a concentrationdependent decrease of estrogen-induced vitellogenin mRNA and protein in trout liver cell in vitro studies. APAP $(0.05 \mathrm{mM})$ produced $50 \%$ inhibition of estradiol-induced vitellogenin production, while $0.3 \mathrm{mM}$ APAP reduced vitellogenin to undetectable levels. ER binding assays indicate that APAP does not reduce binding of [3H]-estradiol at the receptor (Miller et al., 1999). Acetaminophen also failed to show significant receptor binding in a soluble uterine receptor preparation or in an in vivo uterotropic bioassay using immature female mice (Isenhower et al., 1986). However, an NIH study found that uterine, ovarian, and testicular atrophy occurred in rodents fed 25,000ppm APAP and ovarian cysts decreased in rodents fed 3,000-6,000 ppm 
(NTP). Case studies conducted at Harvard Medical School found that APAP use is associated with a decreased risk of ovarian cancer $\left(\right.$ Cramer $_{\mathrm{a}}$ et al., 1998) and alters basal gonadotropin and

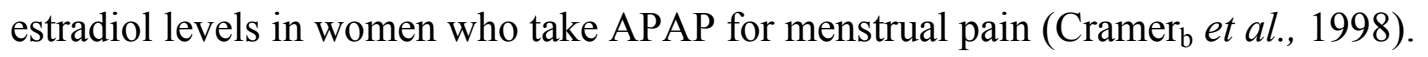

\section{$\underline{\text { Ishikawa Cells as an in vitro estrogen-screen model }}$}

Ishikawa cells are a human endometrial adenocarcinoma cell line established in 1985 from an endometrial adenocarcinoma of a 39-year old woman in Japan. This cell line is estrogen receptor (ER) and progesterone receptor (PR) positive in both in vitro cell cultures and in induced tumors in mice (Hata et al., 1992; Nishada et al., 1985). Kassan et al. (1989) detected two different cytosolic estrogen receptors with Kd values of approximately 0.02 and $6 \mathrm{nM}$. Estradiol has a variety of effects upon Ishikawa cells including: increased cell proliferation (Holinka $\mathrm{a}_{\mathrm{a}}$ et al., 1986); upregulation of progesterone receptors (Holinka $\mathrm{a}_{\mathrm{a}}$ et al., 1986); increased DNA polymerase $\alpha$ activity (Holinka $\mathrm{a}_{\mathrm{a}}$ et al., 1986); increased cerbB2/NEU proto-oncogene protein expression (Markogiamakis et al., 1997); increased intracellular $\beta$-endorphin and release (Makrigiannakis et al., 1992); increased alkaline phosphatase enzyme activity and mRNA (Albert et al., 1990; Holinka $a_{\mathrm{b}}$ et al., 1986). Ishikawa cells are not dependent upon estrogen for cell growth; however, estradiol $\left(\mathrm{E}_{2}\right)$ does stimulate cell proliferation under serum-free and growth factor-free conditions (Holinka et al., 1989; Nishada et al., 1985). The extreme sensitivity of estrogen-inducible alkaline phosphatase in Ishikawa cells makes this cell line ideal for in vitro estrogen-screening bioassays. Studies by Littlefield et al. demonstrate an estrogen microtiter assay that detects alkaline phosphatase activity with maximal stimulation at $10^{-9} \mathrm{M} \mathrm{E}_{2}$, and with detectable stimulation at concentrations as low as $10^{-12} \mathrm{M} \mathrm{E}_{2}$ (Littlefield et al., 1990). 
Antiestrogens have mixed agonist/antagonist activities in Ishikawa cells. 4hydroxytamoxifen (OHT) alone significantly stimulates both alkaline phosphatase activity


but when combined with estradiol OHT inhibits estradiol-induced activity and cell proliferation (Simard et al., 1997; Holinka et al., 1996). Although OHT's partial agonist activities are not well understood, studies by Barsalou et al. (1998) indicate that it has the ability to bind both the estrogen-responsive-element (ERE) and AP1 DNA-binding sites in Ishikawa cells. Alkaline phosphatase activity induced by $\mathrm{E}_{2}$, OHT, Droloxifene or Raloxifene can be overcome by the complete antagonist EM-800 (Simard et al., 1997). Antiestrogen ICI 164,384 inhibits estradiolinduced alkaline phosphatase at the mRNA level (Albert et al., 1990).

\section{Alkaline Phosphatase}

Alkaline phosphatase is an intrinsic membrane protein with a molecular weight of 70,000-125,000 (Ghosh et al., 1968) that exists as a homodimer of homogeneous subunits with the catalytic site exposed on the extracellular side of the plasma membrane (Rustin et al., 1979). This enzyme cleaves phosphate groups from phosphate-esters, and, although not completely understood, it appears to play a role in cell homeostasis and metabolism. In humans alkaline phosphatase exists in 4 different isotypes: intestinal, placental, liver-bone-kidney, and germ cell (Frohlander et al., 1991). Clinically, serum alkaline phosphatase levels are used to screen for bone disease, liver dysfunction, and has been associated with the development of several human cancers such as lung, ovary, gastrointestinal and uterine cancer by the type of isoenzyme detected. 
In Ishikawa cells alkaline phosphatase exists in 3 isoenzymes: intestinal, placental and liver-bone-kidney (McKenna et al., 1979; Mulivor et al., 1985). Immunological assays show that alkaline phosphatase is present in Ishikawa cells in the following proportions: liver-bone-kidney $77.9 \%$, placental $21.7 \%$ and intestinal $<1 \%$ (Albert et al., 1990). In estradiol-stimulated cells the placental isoenzyme increases to $43.1 \%$, liver-bone-kidney decreases to $55.1 \%$ and intestinal remains the same (Albert et al., 1990). 


\section{Hypothesis}

This study tests the hypothesis that APAP will have estrogen-like activity on estrogen-inducible alkaline phosphatase activity in Ishikawa cells. Previous studies demonstrate that APAP has estrogen-like activity in breast cancer cell proliferation studies (HarnageaTheophilus et al., 1998) and inhibits estrogen-induced vitellogenin production in isolated trout liver cells (Miller et al., 1999). No appreciable interactions between APAP and the estrogen receptor have been found (Harnagea-Theophilus et al., 1999, Isenhower et al., 1986) and the mechanism by which APAP alters these estrogenic-responses is unclear. In addition, case studies indicate an association between APAP and lowered risk of ovarian cancer and altered basal hormone levels, including estrogen, in women who take the drug (Cramer ${ }_{\mathrm{a}, \mathrm{b}}$ et al., 1998). Investigation of APAP's estrogen-altering effects is necessary to identify the possible impact, if any, that APAP may have upon estrogen-responsive processes in human health and to identify the mechanism behind this activity. 


\section{Methods}

\section{Cell culture}

Ishikawa endometrial adenocarcinoma cells were a gift from the laboratory of Jacques Simard (CHUL Research Center, Quebec, Canada). Ishikawa cells are maintained in Minimum Essential Media (MEM) (Gibco) supplemented with 10\% fetal bovine serum and $0.1 \%$ gentamycin. Cells are incubated at $37^{\circ} \mathrm{C}, 5 \% \mathrm{CO}_{2}$ and passed by trypsinization when they reach $\sim 80 \%$ confluency.

Studies by Holinka et al. (1989) have shown that Ishikawa cells are able to grow and retain their estrogen-responsiveness in serum-free medium although maximal cell density is lower than estrogen supplemented medium. In order to achieve low basal levels of estrogeninducible alkaline phosphatase activity, at least 2 weeks prior to the beginning of an experiment, cell medium is changed to estrogen-free EFBM consisting of 1:1 combination of phenol red-free Dulbecco's Modified Eagle Medium (PRF-DMEM) (Gibco) and F:12 (Ham) Nutrient Mixture (Gibco), supplemented with 2\% stripped fet al. bovine serum (FBS), 1\% 1-glutamine and 0.1\% gentamycin.

FBS is stripped of steroid hormones by the following charcoal-dextran method. Twenty milligrams of sulfatase (Sigma) are added to $200 \mathrm{ml}$ fet al. bovine serum and incubated at $37^{\circ} \mathrm{C}$ for two hours. Twenty grams of activated charcoal (Sigma) are washed twice by addition of $200 \mathrm{ml}$ deionized $\mathrm{H}_{2} \mathrm{O}$ followed by centrifugation at $3000 \mathrm{rpm}$ for 10 minutes. Two grams of dextran (Sigma) are added to charcoal for 1 hour in $400 \mathrm{ml}$ deionized $\mathrm{H}_{2} \mathrm{O}$ at room temperature using a spin bar. Twenty milliliters of dextran-treated charcoal (DCC) is centrifuged and deionized $\mathrm{H}_{2} \mathrm{O}$ discarded. DCC is added to sulfatase-treated FBS for 30 minutes in a $56^{\circ} \mathrm{C}$ shaker waterbath, followed by centrifugation at $3000 \mathrm{rpm}$ for 10 minutes. The DCC is discarded, and 
serum is treated two more times with DCC for a total of three strippings. Final centrifugation is done at $9,000 \mathrm{rpm}$ for 30 minutes at $5^{\circ} \mathrm{C}$; serum is filter-sterilized and stored at $-20^{\circ} \mathrm{C}$.

\section{Alkaline Phosphatase Activity Determination}

Alkaline phosphatase is an estrogen-inducible gene in Ishikawa Cells and has been used as a marker for estrogen-responsiveness in this cell line (Albert et al., 1990, Holinka et al., 1986). Previous studies have shown that incubating Ishikawa cells for 5 days with increasing concentrations of estradiol caused up to a maximal 15-fold increase in activity compared with non-stimulated controls (Simard et al., 1997). The alkaline phosphatase activity assay is a simple and inexpensive colormetric assay performed in CoStar 96-well cell culture plates as described by Littlefield et al (1990). Enzyme activity is determined by the rate of conversion of the colorless substrate para-nitrophenol phosphate $(\mathrm{pNPhP})$ to yellow colored product paranitrophenol (pNPhOH) by cleavage of an inorganic phosphate group (Henthorn et al., 1988):

\section{alkaline phosphatase$$
p \mathrm{NPh} P+\mathrm{H}_{2} \mathrm{O} \rightarrow p \mathrm{NPhOH}+\mathrm{HPO}_{4}^{-}
$$

As product is formed absorbence increases as measured by spectrophotometer at $405 \mathrm{~nm}$. Alkaline phosphatase activity is determined by calculation from the change in absorbence per minute to the molar concentration of para-nitrophenol produced per minute per well using the $\mathrm{p}$ nitrophenol extinction coefficient. Controls for all experiments include untreated cells to serve as a negative control showing basal level of activity and estradiol treatment as a positive control to indicate estradiol-induced alkaline phosphatase activity. 
Calculations:

Xmoles of product p-nitrophenol per well $=(1 \mathrm{M} \mathrm{p}-\mathrm{NP} / 10,000 \mathrm{abs}$ units $) \times($ change in abs. $/ \mathrm{min}) \times\left(5 \times 10^{-5}\right.$ L)

p-nitrophenol Extinction Coefficient: $1 \mathrm{M}$ p-nitrophenol $\mathrm{Abs}_{405}=10,000$ units

Change in absorbence per minute $=\mathrm{Abs}_{\mathrm{T} 1}-\mathrm{Abs}_{\mathrm{T} 2} /$ minutes $_{\mathrm{T} 1}{ }^{-} \mathrm{T} 2$

\section{Induction of Alkaline Phosphatase:}

A nearly confluent flask of Ishikawa cells in EFBM is harvested with $0.25 \%$ trypsin and plated in CoStar 96-well plates at $7 \times 10^{3}$ cells $/ \mathrm{ml}$ in $100 \mu$ l aliquots. Cells are allowed to adhere to plates for 24 hours followed by addition of test compounds in $50 \mu 1$ aliquots. Cells are exposed to test compounds for 96 hours, with one media change at 48 hours. At the end of the exposure period individual wells are assayed for cellular alkaline phosphatase activity and total cellular protein as determined by fluorescamine. Alkaline phosphatase activity was determined for $\mathrm{n}=5$ wells, and protein determination was $n=3$ per experiment.

At the end of the exposure period media is removed by inversion and plates are rinsed twice by gentle emersion and swirling in 1 liter of phosphate-buffered saline (PBS). PBS is shaken out gently by inversion, and plates is blotted with paper towl. Covered plates fozen at ${ }^{-}$ $80^{\circ} \mathrm{C}$ for at least 10 minutes then thawed at $37^{\circ} \mathrm{C}$ for 3 minutes to lyse cells. Fifty microliters of $5 \mathrm{mM}$ para-nitrophenol phosphate solution $(23.07 \mathrm{mg}$ p-nitrophenol phosphate/10 $\mathrm{ml}$ diethylamine $\mathrm{MgCl}_{2}$ ) are added to each well. Formation of product, para-nitrophenol (pNP), is monitored by a 96-well plate spectrometer (SPECTRAMAX 340PC) at $405 \mathrm{~nm}$ from 0-60 minutes at $30^{\circ} \mathrm{C}$. 


\section{Total Cellular Protein Determination by Fluorescamine}

In addition to alkaline phosphatase enzyme activity, total cellular protein was measured in order to determine to what extent changes in enzyme activity was reflected in protein concentrations.

Fluorescamine is a reagent that reacts instantaneously with amines to produce fluorophors (365nm excitation, 475 emission) by the ninhydrin-phenylacetaldehyde reaction. Fluorescamine as well as its hydrolysis products are nonfluorescent (Udenfriend et al., 1972) (Fig. 4).

Cells in 96 wells are rinsed and freeze-thawed in the same manner as described in Alkaline Phosphatase Activity Assay. To each well, $155 \mu 1$ PBS plus $45 \mu 1$ fluorescamine reagent $(0.018 \mathrm{~g} / 30 \mathrm{ml}$ acetonitrile $)$ are added. Fluorescence is allowed to stabilize for five minutes, then read with fluorimeter (Cytofluor 400) read at 360nm excitation, 460 emission. Bovine serum albumin (BSA) standards are prepared in the range of 0-80ug from a $1 \mathrm{mg} / \mathrm{ml}$ BSA solution and fluorescence is determined for individual wells. Total cellular protein per individual well is extrapolated from the albumin standard curve. 
Figure 4. Ninhydrin-phenylacetaldehyde reaction (Reprinted with permission from Udenfriend, S., et al., (1972) Fluorescamine: a reagent for assay of amino acids, peptides, proteins, and primary amines in the picomole range. Science. Nov 24;178(63):871. Copyright 1972 American Association for the Advancement of Science.)

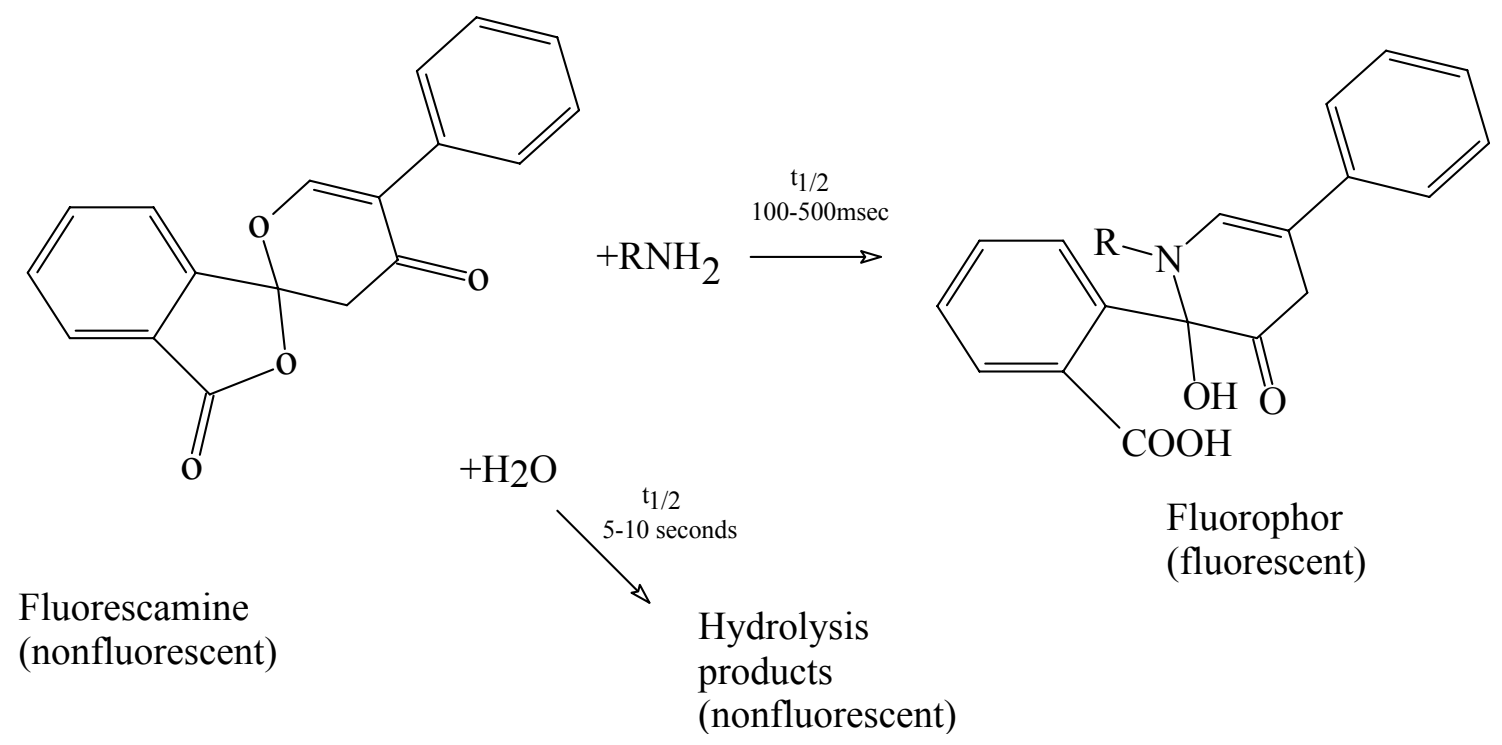

\section{Lactate Dehydrogenase Cytotoxicity Assay}

Lactate dehydrogenase (LDH) is a cytosolic enzyme present in all mammalian cells. The cell membrane is impermeable to LDH under normal healthy conditions; however, damage to the membrane can result in changes in membrane permeability leading to LDH release into the extracellular fluid (Rae et al., 1986). This assay is based on the ability of LDH to catalyze the reaction: 
LDH is measured indirectly as the rate of change in absorbance at $340 \mathrm{~nm}$, which actually reflects the pyruvate-dependent decrease in concentration of NADH but is attributed to the activity of LDH present in the sample. NADH concentrations decrease as LDH catalyzes the reaction of pyruvate to lactate with conversion of one $\mathrm{NADH}$ to $\mathrm{NAD}^{+}$. LDH levels are measured in both cell supernatant and cell lysate and normalized to protein concentration per sample as determined by Bio-Rad Protein Assay.

\section{LDH Determination}

A confluent flask of Ishikawa cells was placed in EFBM 24 hours prior to beginning the experiment. The following day cells were plated at $1.3 \times 10^{6}$ cells/well into CoStar 6 -well plates and allowed to adhere for 24 hours. Cells were treated with $0,0.1 \mathrm{mM}, 0.3 \mathrm{mM}, 1.0 \mathrm{mM}, 10 \mathrm{mM}$ and 20mM APAP, and then assayed at 24 and 96 hours. At the end of the incubation period cell supernatant was removed for determination of LDH released by cells. Supernatant $(400 \mu \mathrm{l})$ was added to $510 \mu 1 \mathrm{LDH}$ prep buffer $(0.2 \mathrm{M}$ potassium phosphate $\mathrm{pH} 7.3), 30 \mu 110 \mathrm{mM}$ Na Pyruvate, $60 \mu 12 \mathrm{mM}$ NADH $(1.42 \mathrm{mg} / \mathrm{ml} 0.1 \mathrm{M}$ potassium phosphate). To disrupt cells and release intracellular LDH, $1 \mathrm{ml} 0.1 \%$ Triton X-100 was added to each well, cells were scraped off the well by cell scraper and pipetted several times to completely disrupt cell membranes, creating a cell lysate. To determine intracellular LDH activity $20 \mu \mathrm{l}$ of cell lysate were added to $890 \mu \mathrm{LDH}$ prep buffer $(0.2 \mathrm{M}$ potassium phosphate $\mathrm{pH} 7.3), 30 \mu 110 \mathrm{mM}$ Na Pyruvate, $60 \mu 12 \mathrm{mM}$ NADH $(1.42 \mathrm{mg} / \mathrm{ml} 0.1 \mathrm{M}$ potassium phosphate). Absorbence was read at 5-second intervals for 60 seconds by continuous read with the spectrophotometer (Bausch and Lomb Spectronic 1001). 


\section{Protein Concentration Determination}

Bio-Rad Protein Assay is based upon the Bradford method, where an acidic dye binds protein in solution (Bradford 1976). The Bio-Rad reagent dye changes color in response to various concentrations of protein and binds primarily basic and aromatic amino acid residues, especially arginine (Compton1985). The absorbance maximum for this protein bound dye occurs at $595 \mathrm{~nm}$ and is read with a spectrometer. Sample protein concentration is extrapolated by comparison to a BSA standard curve. The microassay procedure was modified from the manufacturer's protocol. For the protein standard curve, BSA was prepared at $2 \mathrm{mg} / \mathrm{ml}$ and 8 dilutions were made in the range of $25 \mu \mathrm{g}-2,000 \mu \mathrm{g}$ protein. Cell lysate samples were diluted 1:10 in deionized $\mathrm{H}_{2} \mathrm{O}$. In a CoStar 96-well plate $160 \mu 1$ of diluted sample or standard plus $40 \mu 1$ of concentrated Bio-Rad reagent were added to wells in triplicate. Plates were incubated for 5 minutes at room temperature, and then absorbance was measured at $595 \mathrm{~nm}$ with a spectrometer. Protein concentration per $160 \mu \mathrm{l}$ was extrapolated from absorbence value using the BSA standard curve; protein per well was calculated with the following equation:

Example Calculation:

$\mathrm{X} \mu \mathrm{g}$ protein/well $=(\mu \mathrm{g}$ protein extrapolated from standard curve $) \mathrm{x}(1000 \mu \mathrm{l}$ total sample volume $/ 160 \mu \mathrm{l})$ $\mathrm{x}(10$ dilution factor) 


\section{Effect of Acetaminophen (APAP) on Alkaline Phosphatase Enzyme Activity}

The purpose of this assay was to determine if APAP interacts directly with alkaline phosphatase enzyme, altering its activity. Ishikawa cells were trypsinized, diluted to $2.6 \times 10^{5} \mathrm{cell} / \mathrm{s} / \mathrm{ml}$ and $8 \mathrm{ml}$ of suspension were added to six $100 \mathrm{~mm}$ petri dishes. Cells were incubated for 24 hours at $37^{\circ} \mathrm{C}, 5 \% \mathrm{CO}_{2}$. Three plates were treated with $2 \mathrm{ml}$ of estradiol solution $\left(3 \mu 110 \mathrm{mM} \mathrm{E}_{2}\right.$ in $\left.6 \mathrm{ml} \mathrm{EFBM}\right)$ for a final concentration of $1 \mathrm{nM}$ estradiol to induce alkaline phosphatase activity. Three control plates were dosed with $2 \mathrm{ml}$ of EFBM containing vehicle $(3 \mu 1$ EtOH in 6ml EFBM) and incubated for 72 hours. Medium was removed and plates rinsed twice with PBS. Cells were removed using $0.5 \mathrm{ml}$ PBS and a cell scraper, then pipetted into $15 \mathrm{ml}$ tubes on ice to achieve a final volume of $1.5 \mathrm{ml}$ suspended cells. Cells were lysed by sonication and used for enzyme activity assay and Bio-Rad protein assay.

A concentration-response curve determined that $5 \mu 1$ of cell lysate produced alkaline phosphatase activity within a linear range. In a $96-w e l l$ plate, $5 \mu 1$ cell lysate, $25 \mu 1$ of APAP solution and $50 \mu \mathrm{l}$ of substrate (para-nitrophenol phosphate) were added to wells in triplicate. Estradiol-induced cell lysate was exposed to $2.5,1.0,0.5$ or $0.25 \mathrm{mM}$ APAP. Alkaline phosphatase activity was measured as change in absorbance at $405 \mathrm{~nm}$ as previously described.

\section{Fluorescence Microscopy: Calcein Staining}

The purpose of this experiment was to examine live Ishikawa cells for visible morphological changes after treatment with estradiol and APAP combination. The LIVE/DEAD Viability/Cytotoxicity Assay Kit (Molecular Probes) contains a cell-permeant non-fluorescent calcein AM which is enzymatically converted by intracellular esterases to an impermeable intense green-fluorescence calcein at $495 \mathrm{~nm}$ excitation, $515 \mathrm{~nm}$ emission. While live cells have 
this endogenous esterase activity, dead cells do not. Nonviable cells may have esterase activity present; however, due to compromised cellular membranes they are unable to retain the converted fluorescent product. The method used was adopted from the Fluorescent Microscopy Protocol provided by the manufacturer. Ishikawa cells in EFBM were plated in CoStar 24-well plates at $3 \times 10^{4}$ cells $/ \mathrm{ml}$ in $1 \mathrm{ml}$ aliquots and allowed to adhere to the plates for 24 hours. Cells were treated the next day with $1 \mathrm{nM}$ estradiol plus $0,0.03,0.1,0.3$, or $1 \mathrm{mM}$ APAP and incubated for 72 hours. Control cells were treated with media only. EthD-1 solution $(4 \mathrm{uM})$ was prepared from the $2 \mathrm{mM}$ EthD-1 stock solution $(20 \mu 1 \mathrm{EthD}-1,10 \mathrm{ml} \mathrm{PBS})$. Media was removed from cells and one $\mathrm{ml}$ of dye solution added. Cells were incubated at room temperature for 30 minutes. Cells were viewed and photographed by fluorescent microscopy using a fluorescent filter at $485 \mathrm{~nm}$ excitation, 530nm emission at $80 \mathrm{X}$ magnification.

\section{Statistics}

Statistical analysis of alkaline phosphatase activity, protein concentration and LDH experiments were done by One-Way or Two-Way ANOVA followed by the Tukey's Test when significant differences $(\mathrm{p}<0.5)$ between group means were detected. 


\section{Results}

\section{Estradiol Induction of Alkaline Phosphatase in Ishikawa Cells}

Previous studies have demonstrated that Ishikawa cells have estrogen-responsive alkaline phosphatase activity that responds maximally at $10^{-8} \mathrm{ME}_{2}$, with the highest activity reached 96 hours after $\mathrm{E}_{2}$ addition (Holinka et al., 1986). To ensure that this system was working appropriately in our hands, an $\mathrm{E}_{2}$-concentration-response curve for alkaline phosphatase activity in Ishikawa cells was performed. Cells were treated with $0.003-81 \mathrm{nM}$ estradiol as described in methods; control cells were treated with media only. Results (Fig.5) show that alkaline phosphatase activity was induced in a concentration-dependent manner with concentrations of $0.01-81 \mathrm{nM} \mathrm{E}_{2}$ producing activity significantly higher than control. Maximal induction of alkaline phosphatase activity, $\sim 5$-fold higher than control, was achieved at $0.3,1$ and $3 \mathrm{nM} \mathrm{E}_{2}$, followed by an apparent decline at 9,27 and $81 \mathrm{nM} \mathrm{E}_{2}$.

The amount of total cellular protein in cultures was also determined as described in methods. Results shown in Fig.6 indicate that estradiol increased protein $\sim 1.5$-fold above control at $0.003,0.01,0.03,0.1,0.3$, and $3 \mathrm{nM} \mathrm{E}_{2}$ while $1,9,27$ and $81 \mathrm{nM} \mathrm{E}_{2}$ did not significantly alter protein levels. Although cell protein did increase at some concentrations of $\mathrm{E}_{2}$, this did not occur in a concentration-dependent manner nor was it near the magnitude of increase in the alkaline phosphatase activity measured at corresponding $\mathrm{E}_{2}$ concentrations. These experiments demonstrate that estradiol induced alkaline phosphatase activity in Ishikawa cells and that this increase in activity was only partly attributed to an increase in total cellular protein. 


\section{Acetaminophen Inhibits Basal Alkaline Phosphatase activity in Ishikawa Cells}

Previous studies in our laboratory have shown that APAP induced cell proliferation in ER+ MCF-7 breast cancer cells and that antiestrogens inhibit APAP-induced proliferation (Harnagea-Theophilus et al., 1998). It was hypothesized that APAP would have a similar stimulatory effect on estrogen-inducible alkaline phosphatase activity in Ishikawa cells. Cells were treated as described with $0.03,0.1,0.3$, or $1 \mathrm{mM}$ APAP; control cells were treated with media alone. The concentrations of APAP chosen corresponded with the previous studies conducted with MCF-7 cells (Harnagea-Theophilus et al., 1998). Results in Fig.7 show that APAP did not induce alkaline phosphatase, rather, APAP significantly inhibited basal levels of alkaline phosphatase activity $\sim 50 \%$ compared to control cells. Levels of alkaline phosphatase activity among APAP treated groups were not significantly different from one another. This experiment was repeated 3 more times for a total of 4 experiments, all with the same results. In two of four experiments, 0.3 and $1 \mathrm{mM}$ APAP treatment decreased total cellular protein $20 \%$ and $60 \%$ respectively, relative to control cells (Fig. 8). In the other two experiments, total cellular protein was not significantly altered by APAP (not shown).

Results from this experiment do not support the initial hypothesis that APAP would increase estrogen-inducible alkaline phosphatase in Ishikawa cells. Acetaminophen decreases basal levels of alkaline phosphatase activity and this effect may be in part due to decreases in total cellular protein at 0.3 and $1 \mathrm{mM}$ APAP concentrations.

\section{Acetaminophen Inhibits Estradiol-Induced Alkaline Phosphatase}

The purpose of the next experiment was to determine if APAP would have the same inhibitory affect upon estradiol-induced alkaline phosphatase activity as it did on the basal 
enzyme activity. Cells were treated with $1 \mathrm{nM} \mathrm{E}_{2}$ plus $0.03,0.1,0.3$, or $1 \mathrm{mM}$ APAP; control cells were treated with media only. The concentration of $1 \mathrm{nM} \mathrm{E} \mathrm{E}_{2}$ was chosen because it induced a strong yet submaximal alkaline phosphatase activity (Fig. 5). Results (Fig.9) show that 1nM E 2 induced alkaline phosphatase activity $\sim 9$-fold above control level and that $0.1,0.3,1 \mathrm{mM}$ APAP inhibited this activity by $29 \%, 62 \%$ and $91 \%$, respectively. The effects of $E_{2}$ and APAP on total protein levels (Fig.10) show that estradiol (1nM) alone had no significant effect on protein concentration, while the combination of $1 \mathrm{nM} \mathrm{E}_{2}$ plus 0.3 or $1 \mathrm{mM}$ APAP significantly decreased protein concentration compared to both control and 1nM E 2 ; protein concentrations decreased 35 and $70 \%$, respectively, compared to $1 \mathrm{nM} \mathrm{E}_{2}$. These data are representative of 4 experiments.

These experiments indicate that APAP inhibits estradiol-induced alkaline phosphatase activity in a concentration-dependent manner at $0.1,0.3$ and $1 \mathrm{mM}$ concentrations. Acetaminophen also decreases estradiol-induced protein concentrations at 0.3 and $1 \mathrm{mM}$ significantly lower than both control and estradiol-treated cells, suggesting that it may be toxic at these levels.

\section{Lactate Dehydrogenase Cytotoxicity Assay}

In order to determine if cytotoxicity was playing a role in APAP's inhibitory effect on E2-induced alkaline phosphatase activity, a lactate dehydrogenase (LDH) release assay was conducted, which is a well-characterized marker of cell cytotoxicity (Ray et al., 2000). Ishikawa cells were plated and treated with $0.1,0.3,1,10$ or 20mM APAP; control cells were treated with media alone. High APAP concentrations (10 and 20mM) were used in this study as positive controls for toxicity. Intracellular LDH activity obtained from cell lysate and LDH activity released into medium were determined after 24 and 96-hours of exposure as shown in Table 1; 
intracellular and released LDH activity were normalized to total cellular protein as obtained from cell lysate. Total LDH activity was the sum of intracellular and released LDH activity. Percentage released from total LDH expresses the amount of LDH activity released into the media as a percentage of the total LDH per well.

After 24-hours cells treated with 0.3, 1, 10 and 20mM APAP showed a decline in intracellular LDH activity. Released LDH activity increased slightly when cells were exposed to 1 and 20mM APAP; 10mM APAP-treated cells released LDH almost 4-times higher than control but this effect was not reproducible. This indicates that after 24-hours there is little toxicity in Ishikawa cells exposed to APAP at the concentrations tested. By 96-hours LDH release increased dramatically in cells treated with 1, 10 and 20mM APAP compared to control; LDH release increased to a lesser degree in $0.3 \mathrm{mM}$ APAP-treated cells. Intracellular LDH remained lower in 0.3, 1, 10 and 20mM APAP-treated cells compared to control. In summary, after 96-hours of exposure Ishikawa cells may show signs of toxicity with $0.3 \mathrm{mM}$ APAP treatment, and at 1,10 and $20 \mathrm{mM}$ APAP toxicity is apparent. 
Table 1. Effect of APAP on LDH Release from Ishikawa Cells

\begin{tabular}{|c|c|c|c|c|c|c|}
\hline \multicolumn{7}{|l|}{ 24-hours } \\
\hline$\underline{\text { Total LDH* }}{ }^{*}$ & 1.49 & 1.43 & 1.16 & 1.09 & 1.03 & 1.22 \\
\hline$\overline{\text { Intracellular* }}$ & 1.46 & 1.41 & 1.14 & 1.06 & 0.95 & 1.18 \\
\hline Released* & 0.03 & 0.02 & 0.02 & 0.03 & 0.08 & 0.04 \\
\hline $\begin{array}{c}\% \text { released of total } \\
L D H\end{array}$ & $l \quad 2 \%$ & $1.4 \%$ & $1.7 \%$ & $2.8 \%$ & $7.8 \%$ & $3.3 \%$ \\
\hline \multicolumn{7}{|l|}{ 96-hours } \\
\hline Total LDH ${ }^{*}$ & 2.05 & 2.33 & 1.90 & 1.16 & 1.09 & 0.84 \\
\hline Intracellular* & 1.97 & 2.24 & 1.76 & 0.91 & 0.89 & 0.47 \\
\hline Released* & 0.08 & 0.09 & 0.14 & 0.25 & 0.20 & 0.37 \\
\hline $\begin{array}{l}\% \text { released of total } \\
L D H\end{array}$ & $l 3.9 \%$ & $3.9 \%$ & $7.4 \%$ & $21.6 \%$ & $18.4 \%$ & $44.1 \%$ \\
\hline
\end{tabular}

Table 1. Cells were treated with $0.1,0.3,1,10$ or 20mM APAP and assayed for LDH activity at 24 and 96-hours. Following exposure period, media removed from cells was assayed for released LDH activity and cell lysate was prepared and assayed for intracellular LDH activity and total cellular protein. Intracellular represents total cellular LDH activity $\left(* \Delta \mathrm{Abs}_{340 \mathrm{~nm}} / \mathrm{min} / \mathrm{mg}\right.$ total cellular protein); released LDH represents total LDH activity released into medium $\left(* \Delta \mathrm{Abs}_{340 \mathrm{~nm}} / \mathrm{min} / \mathrm{mg}\right.$ total cellular protein); total LDH is the sum of intracellular and released $\mathrm{LDH}$. Percentage of total LDH released expresses the amount of LDH activity released into the media as a percentage of the total LDH per well. While treatment with APAP for 24-hours did not affect LDH release, after 96-hours there was an increase in \%LDH release in $0.3,1,10$ and 20mM APAP-treated cells indicating cytotoxicity.

\section{Alkaline Phosphatase Enzyme Is Not Directly Inhibited By Acetaminophen}

The next experiment was designed to determine if APAP directly inhibits alkaline phosphatase enzyme activity. Cells were plated, treated with estradiol to induce alkaline phosphatase and a cell lysate containing alkaline phosphatase was prepared as described in methods. Alkaline phosphatase assays were conducted in the absence (control) or presence of 0.25. $0.5,1.0$ or $2.5 \mathrm{mM}$ APAP. Alkaline phosphatase specific activity $\left(\mathrm{abs}_{405 \mathrm{~nm}} / \mathrm{min} / \mu \mathrm{g}\right.$ prot$)$ was determined and is presented in Table 1. Results from this experiment indicate that none of the APAP concentrations tested directly inhibit the enzymatic activity of alkaline phosphatase. Experiment was done in duplicate with analogous results. 
Table 2. Effect of APAP on Alkaline Phosphatase Enzyme Activity

\begin{tabular}{|c|c|c|c|c|}
\hline Control & 0.25mM APAP & 0.5mM APAP & 1.0mM APAP & 2.5mM APAP \\
\hline 0.81 & 0.85 & 0.85 & 0.98 & 0.89 \\
\hline
\end{tabular}

Table 2. Ishikawa cell lysate containing estradiol-induced alkaline phosphatase was treated with $0.25,0.5,1.0$ or $2.5 \mathrm{mM}$ APAP and assayed for enzyme activity. Specific activity* $\left(\Delta \mathrm{Abs}_{340 \mathrm{~nm}} / \mathrm{min} / \mathrm{mg}\right.$ total cellular protein) of estradiol-induced alkaline phosphatase enzyme was not altered by addition of APAP.

\section{Effects of Varying Concentrations of $E_{2}$ and APAP on Alkaline Phosphatase Activity and Protein Concentration}

The next set of experiments was designed to determine if the degree of APAP inhibition of alkaline phosphatase activity was affected by the concentration of $\mathrm{E}_{2}$ (Table 3). Cells were treated with either $0.01,0.1$ or $1 \mathrm{nM} \mathrm{E}_{2}$ in combination with $0,0.03,0.1,0.3$, or $1 \mathrm{mM}$ APAP; control cells were treated with media only. At 1mM APAP, $\mathrm{E}_{2}$-induced alkaline phosphatase activity decreased approximately $77 \%$ at all $\mathrm{E}_{2}$-concentrations examined. Inhibition of estradiolinduced alkaline phosphatase activity at $0.3 \mathrm{mM}$ APAP ranged from $16 \%$ to $34 \%$ and was not dependent on the concentration of $E_{2}$. At 0.1 and $0.03 \mathrm{mM}$ APAP, estradiol-induced alkaline phosphatase activity was not significantly inhibited. Furthermore, alkaline phosphatase activity was significantly increased in Ishikawa cells treated with $0.01 \mathrm{nM} \mathrm{E}_{2}$ plus $0.03 \mathrm{mM}$ APAP. Results shown in Table 3 indicate that APAP inhibition of estradiol-induced alkaline phosphatase activity does not change significantly with increasing concentrations of estradiol. Protein concentrations were decreased at all estradiol concentrations with 1mM APAP, and less dramatically at $0.3 \mathrm{mM}$ APAP. Treatment with 0.1 or $0.03 \mathrm{mM}$ APAP had little, if any, effect on protein concentrations at 0.01 and $1 \mathrm{nM} \mathrm{E}_{2} ; 0.01 \mathrm{nM} \mathrm{E}_{2}$ showed slightly lower protein concentrations for all APAP treatments, compared to the other two estradiol-treatment groups. 
There is some similarity between trends in decreased estradiol-induced alkaline phosphatase activity and protein concentrations in response to different concentrations of APAP. However, the magnitude of inhibition of estradiol-induced alkaline phosphatase activity is not equivalent to the decrease in protein for the majority of treatment groups. APAP (1mM ) substantially decreased $\mathrm{E}_{2}$-induced alkaline phosphatase activity relative to protein concentrations. Increased estradiol-induced alkaline phosphatase activity at 0.03 and $0.1 \mathrm{mM}$ APAP does not correlate to protein data, as protein concentrations decrease slightly or do not change compared to controls. Cells treated with $0.3 \mathrm{mM}$ APAP plus $0.01,0.1$ or $1 \mathrm{nM} \mathrm{E}_{2}$ showed some similarity between alkaline phosphatase activity and protein levels. These results indicate that APAP does affect cellular protein concentrations of estradiol-treated Ishikawa cells; however, this is not always equal to the magnitude of the effect APAP appears to have on estradiol-induced alkaline phosphatase activity. Therefore, it appears that APAP reduces estradiol-induced alkaline phosphatase activity more than it reduces cellular protein, and this effect does not change with increasing concentrations of $E_{2}$. 


\section{Table 3. Changes in alkaline phosphatase activity and protein concentration with} varying combinations of $E_{2}$ and APAP

\begin{tabular}{|c|c|c|c|c|}
\hline \multicolumn{5}{|c|}{$E_{2}$-induced Alkaline Phosphatase Activity $\%$ of $E_{2}$ control } \\
\hline & $0.03 \mathrm{mM}$ APAP & $0.1 \mathrm{mM}$ APAP & 0.3mM APAP & $1 \mathrm{mM}$ APAP \\
\hline $0.01 n M E_{2}$ & $137 \pm 18.6$ & $115 \pm 9.5$ & $70.5 \pm 3.3$ & $22.5 \pm 3.7$ \\
\hline $0.1 \mathrm{nM} \mathrm{E}_{2}$ & $91.3 \pm 12.1$ & $109 . \overline{8} \pm 10.8$ & $83.5 \pm 7.0$ & $23.3 \pm 3.6$ \\
\hline $\ln M E_{2}$ & $106.8 \pm 4.2$ & $90.8 \pm 6.9$ & $65.5 \pm 9.5$ & $23.5 \pm 6.4$ \\
\hline \multicolumn{5}{|c|}{ Total Protein $\%$ of $E_{2}$ control } \\
\hline & $\mathbf{0 . 0 3 n}$ & $0.1 \mathrm{n}$ & 0.3mM APAP & 1mM APAP \\
\hline $0.01 n M I$ & $92.0 \pm 6.7$ & $99.6 \pm 6.7$ & $76.8 \pm 8.5$ & $79.2 \pm 13.4$ \\
\hline $0.1 \mathrm{nM} \mathbf{E}_{2}$ & $87.8 \pm 8.6$ & $79.3 \pm 5.5$ & $68.8 \pm 18.4$ & $43.3+15.8$ \\
\hline $\ln M E_{2}$ & $90.8 \pm 15.1$ & $92.8 \pm 8.2$ & $83.3 \pm 8.7$ & $59.3 \pm 28.6$ \\
\hline
\end{tabular}

Cells were plated in 96-well plates and exposed to varying concentrations of $E_{2}$ and APAP. After 96hours incubation with test compounds, individual wells were assayed for alkaline phosphatase activity or protein concentration by fluorescamine. Results shown are the mean of 4 experiments, with individual treatment group data expressed as percent of activity or protein concentration compared to the corresponding estradiol-only treatment group (100\%) from that experiment. Control cells treated with media were used to indicate induction of alkaline phosphatase activity by $E_{2}$ (not shown). Results show that increasing concentrations of $E_{2}$ did not significantly alter the effect of APAP on alkaline phosphatase or protein concentrations at the various concentrations tested. Standard error is shown.

\section{APAP Amplifies Antiestrogen Effects in Ishikawa Cells}

The next study tested the hypothesis that APAP would enhance the inhibitory effect of antiestrogens on $\mathrm{E}_{2}$-induced alkaline phosphatase. Previous studies demonstrated antiestrogens inhibit $\mathrm{E}_{2}$-induced alkaline phosphatase activity in Ishikawa cells (Holinka et al., 1986; Simard et al.,1997; Littlefield et al.,1990). Cells were treated with $0.1 \mathrm{nM} \mathrm{E}_{2}$ in combination with 0.01, 0.1, 1 or $10 \mu \mathrm{M}$ 4-hydroxy tamoxifen (OHT) (Sigma) or ICI 182,780 (Zeneca Pharmaceuticals); control cells were treated with media only. Concentrations of anti-estrogens were chosen based upon current literature (Holinka et al.,1986; Simard et al.,1997; Littlefield et al.,1990). The concentration of $0.1 \mathrm{nM} \mathrm{E}_{2}$ was chosen because it induced submaximal alkaline-phosphatase activity within the linear range. Results shown are representative of experiments done in triplicate. Treatment with $0.01,0.1$, or $1 \mu \mathrm{M} \mathrm{OHT}$ inhibited $\mathrm{E}_{2}$-induced alkaline phosphatase 
activity $\sim 45 \%$ from $1 \mathrm{nM} \mathrm{E}_{2}$-treated cells (Fig.11), with no significant differences between alkaline phosphatase activity of the different OHT treatment groups, while $10 \mu \mathrm{M}$ OHT eliminated $\mathrm{E}_{2}$-induced alkaline phosphatase activity completely. Fig. 12 shows that $\mathrm{OHT}$ had no significant effect on cellular protein concentrations except at $10 \mu \mathrm{M}$ where protein declined to almost zero, indicating a toxic effect., In one of the two experiments $0.01 \mu \mathrm{M}$ OHT decreased protein $32 \%$ compared to $1 \mathrm{nM} \mathrm{E}_{2}$, but this data was inconsistent with the other data.

Results in Fig.13 show that ICI 182,780 inhibits $\mathrm{E}_{2}$-induced alkaline phosphatase activity 95\% relative to cells treated with $1 \mathrm{nM} \mathrm{E}_{2}$ alone. Fig. 14 shows an ICI 182,780 concentrationdependent decrease in cellular protein, with $0.1,1$ and $10 \mu \mathrm{M}$ ICI resulting in $27 \%, 36 \%$ and $61 \%$ decrease, respectively. Results for both antiestrogens shown are representative of two separate experiments with similar results.

The next part of this experiment was to examine the effect of APAP in combination with OHT, on $\mathrm{E}_{2}$-induced alkaline phosphatase. Cells were plated and treated as described in methods with either $0.1 \mathrm{nM} \mathrm{E}_{2}, 0.1 \mathrm{nM} \mathrm{E}_{2}+0.01 \mu \mathrm{M} \mathrm{OHT}$, or $0.1 \mathrm{nM} \mathrm{E}_{2}+0.01 \mu \mathrm{M} \mathrm{OHT}+0.03,0.1,0.3$ or $1 \mathrm{mM}$ APAP. The concentration $0.01 \mu \mathrm{M}$ OHT was chosen because it was the lowest concentration that produced significant inhibition of $0.1 \mathrm{nM} \mathrm{E}_{2}$-induced alkaline phosphatase activity. Results (Fig.15) show that $0.1 \mathrm{nM} \mathrm{E}_{2}$ induced alkaline phosphatase activity $\sim 7.5$-fold, and this was decreased $\sim 65 \%$ by $0.01 \mu \mathrm{M}$ OHT. Addition of $0.1,0.3$ and $1 \mathrm{mM}$ APAP enhanced this inhibition of activity by an additional $38 \%, 71 \%$ and $90 \%$ compared to OHT alone. Protein concentrations (Fig.16) were doubled by $0.1 \mathrm{nM} \mathrm{E}_{2}$ compared to control and were unaffected by addition of $0.01 \mu \mathrm{M}$ OHT alone. Addition of 0.3 and $1 \mathrm{mM}$ APAP decreased protein concentrations $36 \%$ and $73 \%$ compared to $\mathrm{E}_{2}$ plus $\mathrm{OHT}$ alone, while lower concentrations produced no significant effect. Again, although APAP produced a significant decrease in cellular 
protein concentrations in some treatment groups, the effectsproduced do not account for the total reduction of enzyme activity.

\section{Fluorescent Microscopy}

Calcein fluorescent staining was utilized to show morphological changes in live Ishikawa cells in response to $\mathrm{E}_{2}$ and APAP treatments (Fig.17). Cell permeant non-fluorescent calcein is enzymatically converted to an impermeable green-fluorescent product by esterases and retained in the cell. Results show that Ishikawa cells in the control group grow in large clusters adhered to the plate with individual cells well defined. $1 \mathrm{nM} \mathrm{E}_{2}$-treated cells appear similar to those of control. Cells treated with $1 \mathrm{nM} \mathrm{E}_{2}+0.03 \mathrm{mM}$ APAP do not appear drastically altered, but clusters of cells are smaller. Cells treated with $1 \mathrm{nM} \mathrm{E}_{2}+0.1 \mathrm{mM}$, or $0.3 \mathrm{mM}$ APAP appear more misshapen and there are less cells in the particular fields photographed. Ishikawa cells treated with $1 \mathrm{nM} \mathrm{E}_{2}+1 \mathrm{mM}$ APAP were distorted and most cells no longer adhered to the plate, indicating toxicity. 


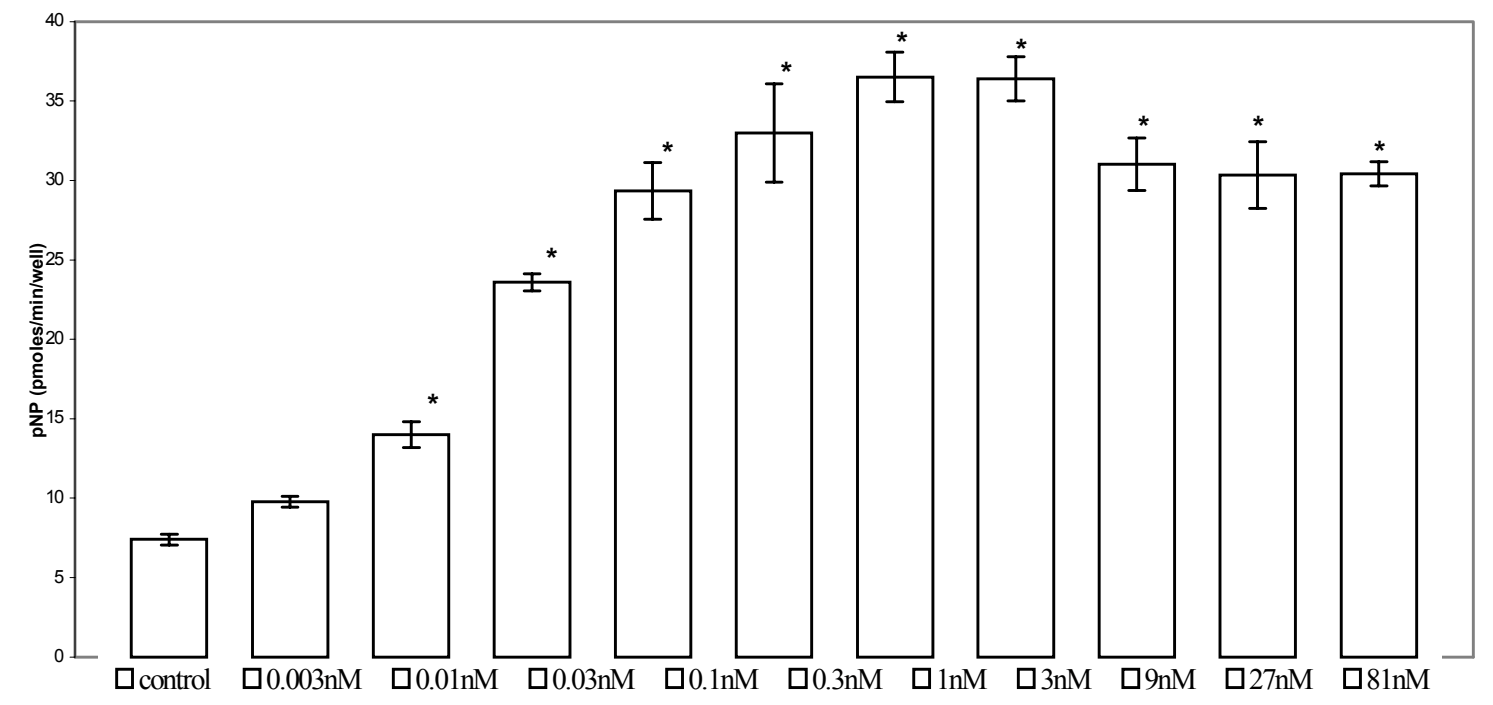

Fig.5. Estradiol induces alkaline phosphatase activity in Ishikawa cells. Cells were plated in 96-well plates and exposed to $0.003-81 \mathrm{nM} \mathrm{E}_{2}$ for 96-hours, then assayed for alkaline phosphatase activity. Alkaline phosphatase was induced in a concentration-dependent manner with maximal activity at $1 \mathrm{nM} \mathrm{E}$, approximately 5-fold higher than control levels. Each point represents the mean \pm standard error of five individual wells from a single experiment; a total of four experiments were conducted with similar results. *Activity increased significantly compared to control $(\mathrm{p}<0.05)$. 


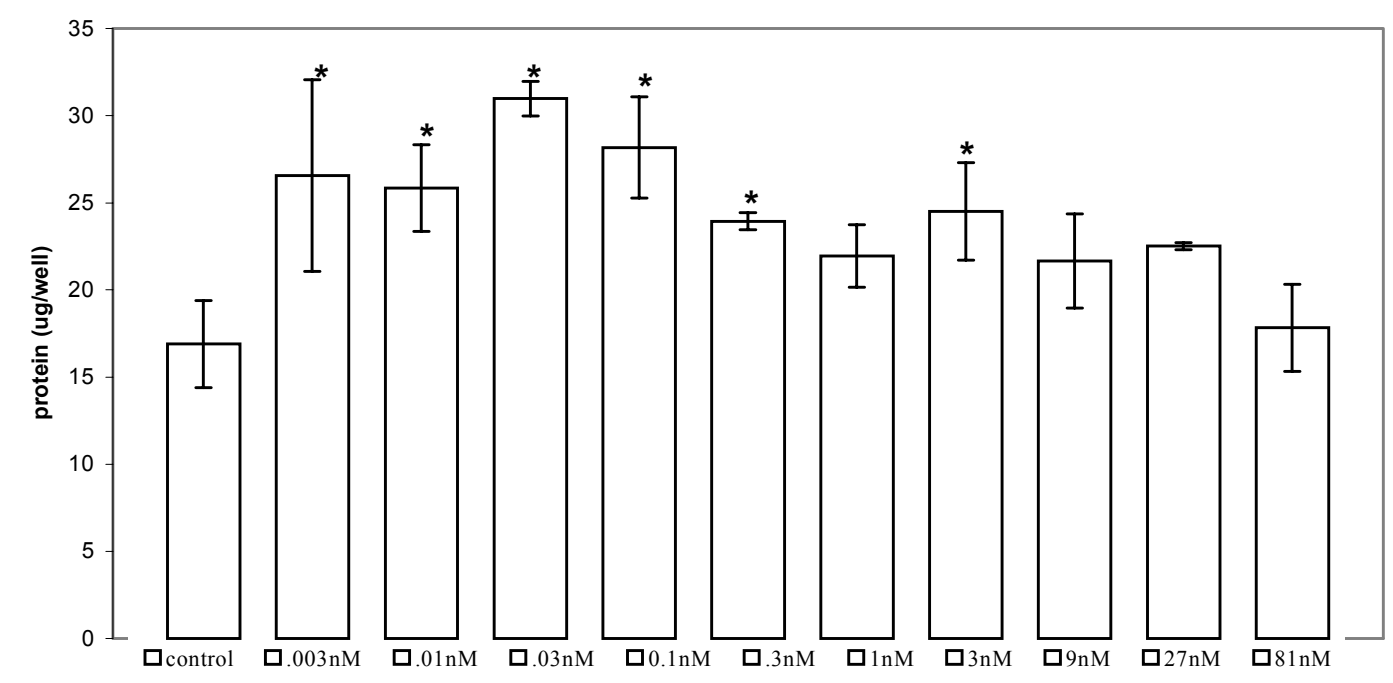

Fig.6. Estradiol increases total cellular protein concentrations in Ishikawa cells. Cells were plated in $96-w e l l$ plates and exposed to $0.003-81 \mathrm{nM} \mathrm{E}_{2}$ for 96 -hours, then assayed for total cellular protein by fluorescamine assay. Protein concentrations increased 1.5-fold with 0.003$0.3 \mathrm{nM} \mathrm{E}_{2}$-treatment, but not in a concentration-dependent manner. Each point represents the mean \pm standard error of four individual wells from a single experiment; a total of four experiments were conducted with similar results. *Protein concentration increased significantly compared to control $(\mathrm{p}<0.05)$. 


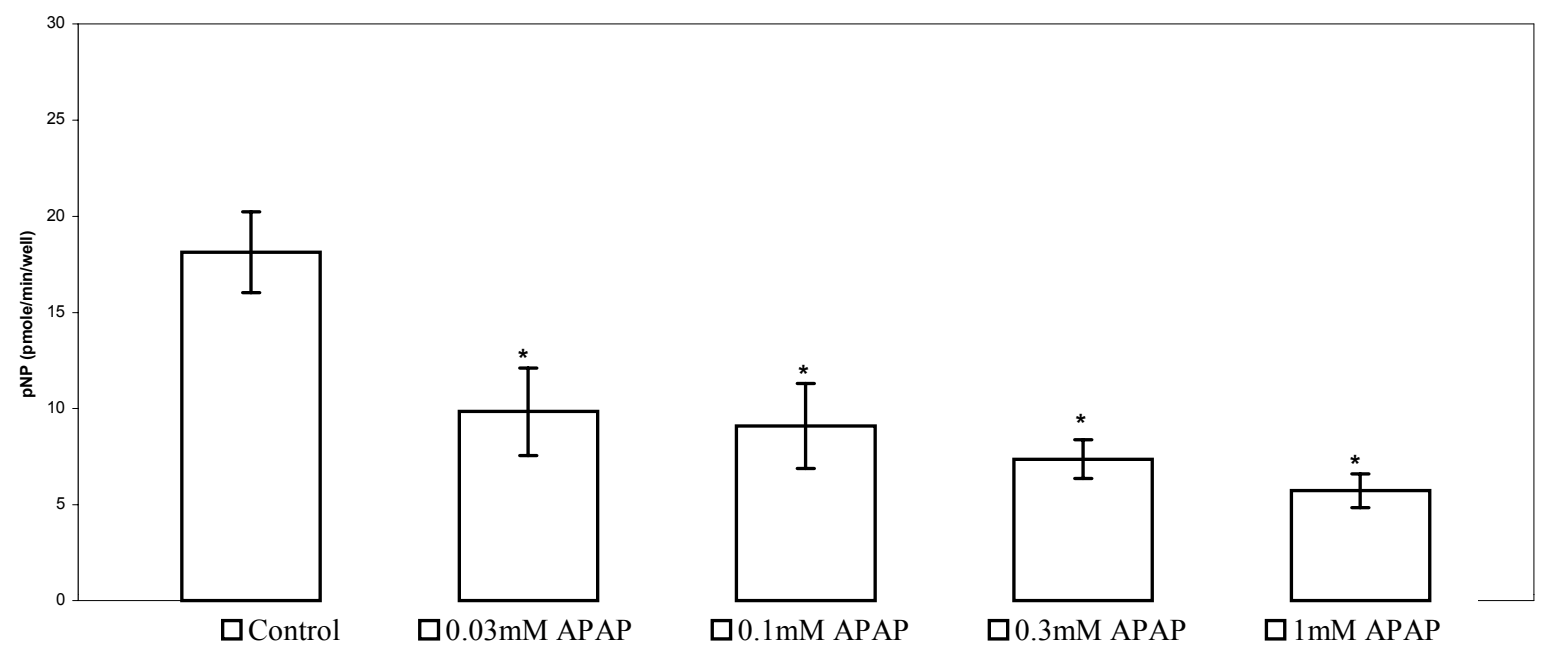

Fig.7. Acetaminophen (APAP) inhibits basal alkaline phosphatase activity in Ishikawa cells. Cells were plated in 96-well plates and exposed 0.03, 0.1, 0.3, and 1mM APAP for 96hours, then assayed for alkaline phosphatase activity. Alkaline phosphatase was significantly inhibited by APAP treatment at all concentrations tested compared to control cells. Each point represents the mean \pm standard error of five individual wells from a single experiment; a total of four experiments were conducted with similar results. *Activity decreased significantly compared to control $(\mathrm{p}<0.05)$. 


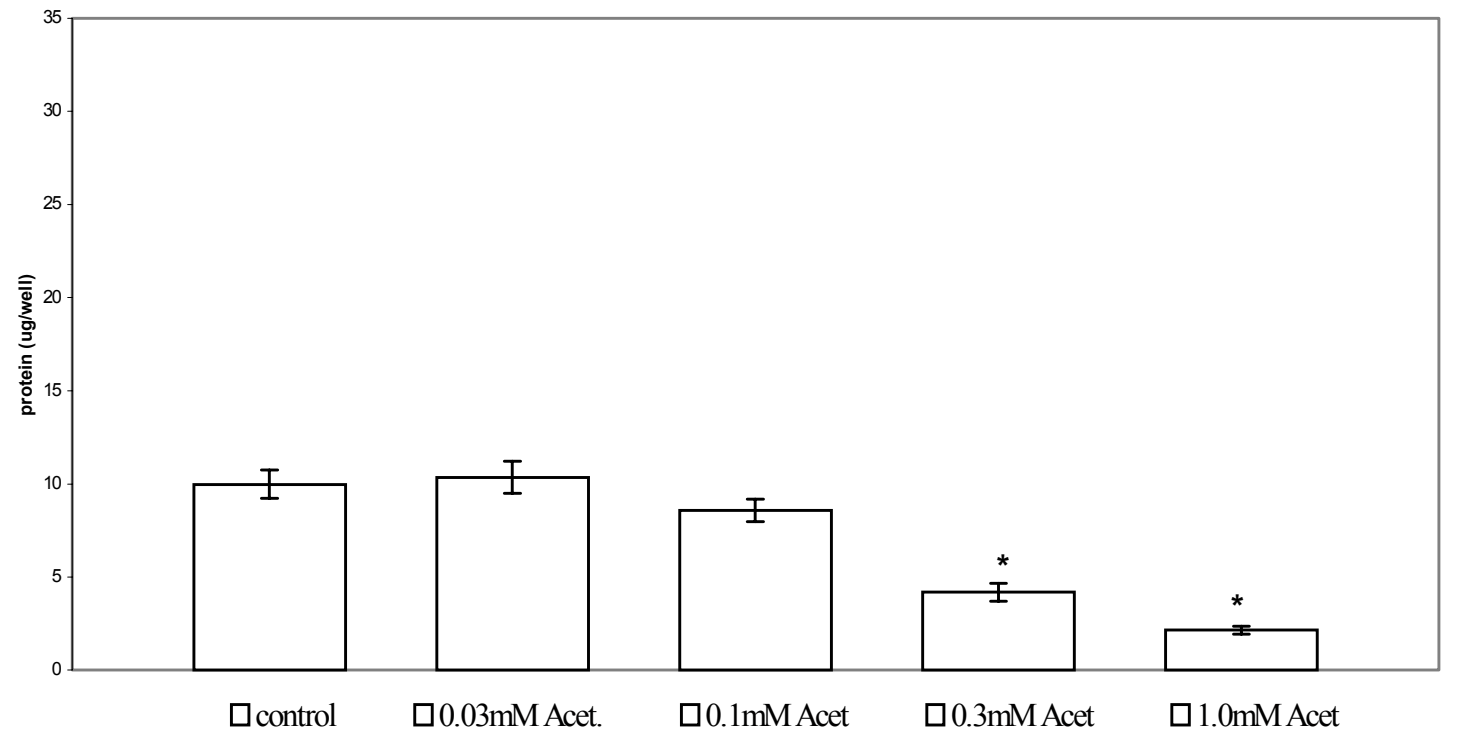

Fig.8. Acetaminophen (APAP) decreases total cellular protein in Ishikawa cells. Cells were plated in 96-well plates and exposed 0.03, 0.1, 0.3, and 1mM APAP for 96-hours, then assayed for total cellular protein by fluorescamine assay. Protein concentrations were unaffected by treatment with 0.03 and $0.1 \mathrm{mM}$ APAP, but were significantly decreased by 0.3 and $1 \mathrm{mM}$ APAP compared to control. Each point represents the mean \pm standard error of four individual wells from a single experiment; a total of four experiments were conducted with similar results. *Protein concentration decreased significantly compared to control $(\mathrm{p}<0.05)$. 


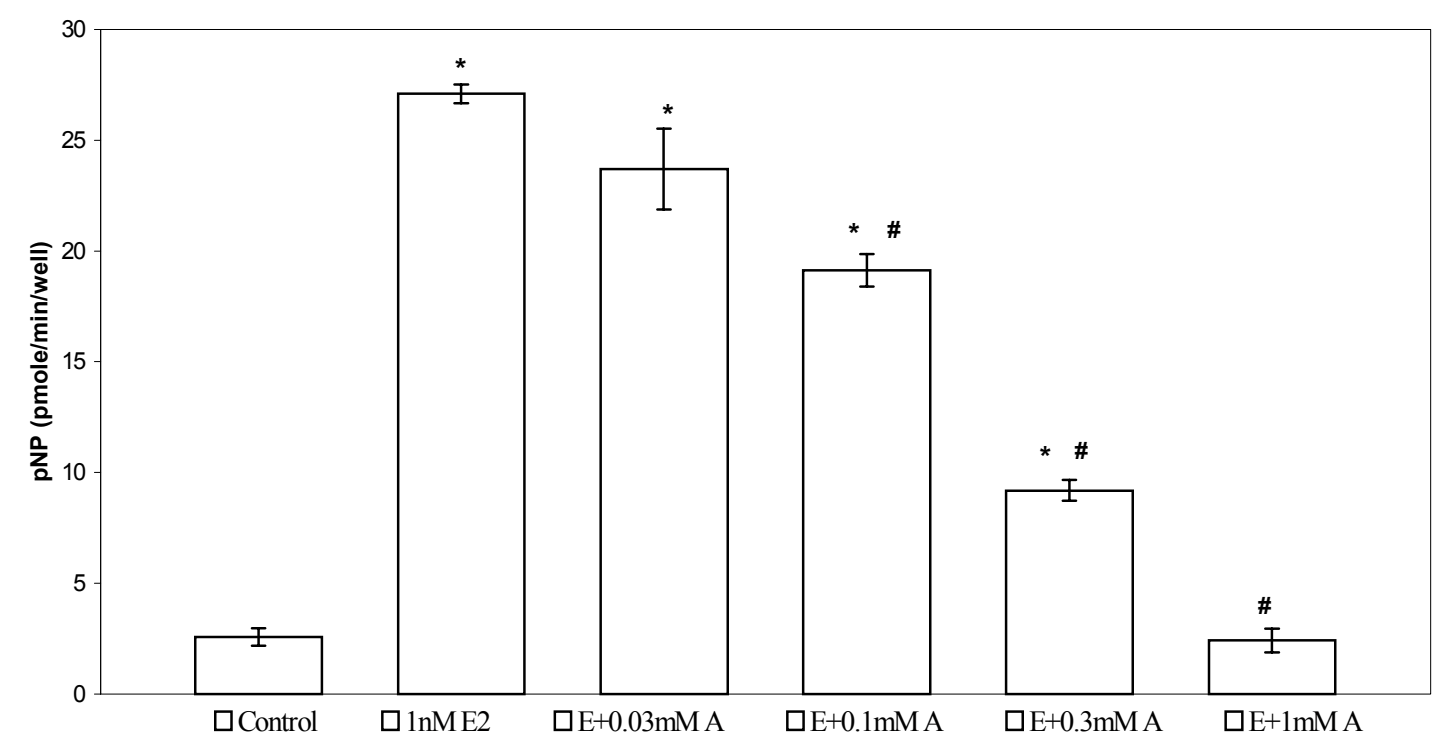

Fig.9. Acetaminophen (APAP) inhibits $\mathbf{E}_{2}$-induced alkaline phosphatase activity in

Ishikawa cells. Cells were plated in 96-well plates and exposed to $1 \mathrm{nM} \mathrm{E}_{2}$, or a combination of $1 \mathrm{nM} \mathrm{E}_{2}$ and $0.03,0.1,0.3,1 \mathrm{mM}$ APAP for 96-hours, then assayed for alkaline phosphatase activity. Alkaline phosphatase was induced by $1 \mathrm{nM} \mathrm{E} \mathrm{E}_{2}$; combinations of $1 \mathrm{nM} \mathrm{E} \mathrm{E}_{2}$ and $0.1,0.3$, and $1 \mathrm{mM}$ APAP had significantly decreased alkaline phosphatase activity compared to $1 \mathrm{nM} \mathrm{E}_{2}$ alone. This inhibition of activity increased with increasing concentrations of APAP. Cells treated with $1 \mathrm{nM} \mathrm{E} \mathrm{E}_{2}+1 \mathrm{mM}$ APAP had alkaline phosphatase activity decreased below control levels. Each point represents the mean \pm standard error of five individual wells from a single experiment; a total of four experiments were conducted with similar results. *Activity increased significantly compared to control $(\mathrm{p}<0.05)$. ${ }^{\#}$ Activity decreased significantly compared to $1 \mathrm{nM}$ $\mathrm{E}_{2}(\mathrm{p}<0.05)$ 


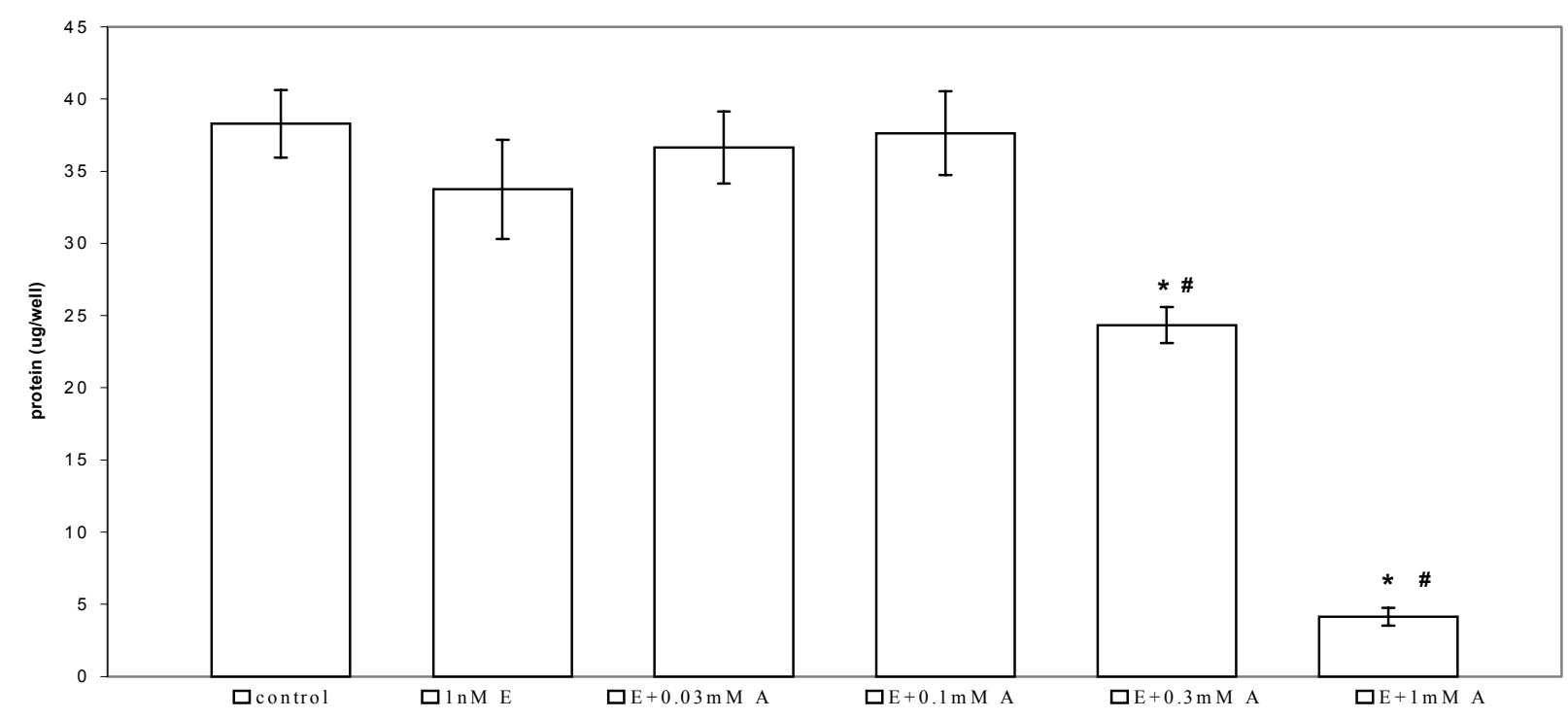

Fig.10. Acetaminophen (APAP) decreases total cellular protein concentrations in $\mathrm{E}_{2^{-}}$

treated Ishikawa cells. Cells were plated in 96-well plates and exposed to $1 \mathrm{nM} \mathrm{E}_{2}$, or a combination of $1 \mathrm{nM} \mathrm{E}_{2}$ and $0.03,0.1,0.3,1 \mathrm{mM}$ APAP for 96-hours, then assayed for total cellular protein by fluorescamine assay. While $1 \mathrm{nM} \mathrm{E}_{2}$ alone had no effect on protein concentration, combination of $1 \mathrm{nM} \mathrm{E}_{2}$ and 0.3 , or $1 \mathrm{mM} \mathrm{APAP}$ significantly decreased total cellular protein in comparison to control. Each point represents the mean \pm standard error of four individual wells from a single experiment; a total of four experiments were conducted with similar results. *Protein concentration decreased significantly compared to control $(\mathrm{p}<0.05)$. ${ }^{\text {\# }}$ Protein concentration decreased significantly compared to $1 \mathrm{nM} \mathrm{E}_{2}(\mathrm{p}<0.05)$. 




Fig.11. Tamoxifen inhibits $\mathbf{E}_{2}$-induced alkaline phosphatase activity in Ishikawa cells. Cells were plated in 96-well plates and exposed to $1 \mathrm{nM} \mathrm{E}_{2}$, or a combination of $1 \mathrm{nM} \mathrm{E}_{2}$ and $0.01,0.1$, $1,10 \mu \mathrm{M}$ OHT for 96-hours, then assayed for alkaline phosphatase activity. OHT significantly decreased alkaline phosphatase activity by $\sim 50 \%$ in cells treated with $1 \mathrm{nM} \mathrm{E}_{2}$ and $0.01,0.1 \mu \mathrm{M}$ OHT; there was no detectable activity in cells treated with $1 \mathrm{nM} \mathrm{E}_{2}$ plus $10 \mu \mathrm{M}$ OHT. Each point represents the mean \pm standard error of five individual wells from a single experiment; a total of four experiments were conducted with similar results. *Activity significantly different from control $(\mathrm{p}<0.05)$. ${ }^{\#}$ Activity decreased significantly compared to $1 \mathrm{nM} \mathrm{E}_{2}(\mathrm{p}<0.05)$. 


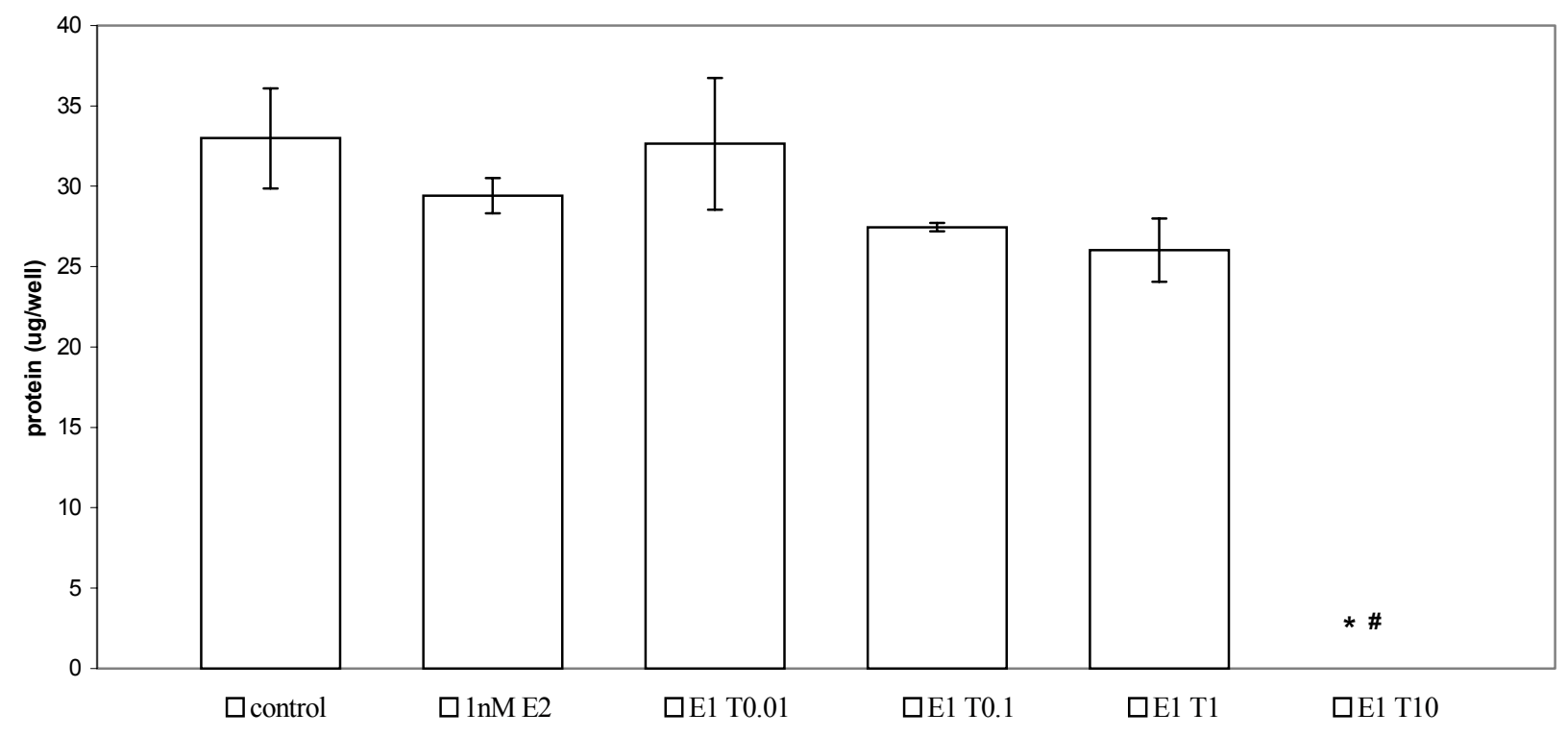

Fig.12. Tamoxifen decreases total cellular protein concentrations in $E_{2}$-treated Ishikawa cells. Cells were plated in 96-well plates and exposed to $1 \mathrm{nM} \mathrm{E}_{2}$, or a combination of $1 \mathrm{nM} \mathrm{E}_{2}$ $0.01,0.1,1,10 \mu \mathrm{M}$ OHT for 96 -hours, then assayed for total cellular protein by fluorescamine assay. Treatment with $1 \mathrm{nM} \mathrm{E}_{2}$ or combination of $1 \mathrm{nM} \mathrm{E}_{2} 0.01,0.1,1 \mu \mathrm{M} \mathrm{OHT}$ had no effect on cellular protein concentrations compared to control, however, $1 \mathrm{nM} \mathrm{E}_{2}$ plus $10 \mu \mathrm{M}$ OHT decreased protein levels to almost zero indicating toxicity. Each point represents the mean $\underline{ \pm}$ standard error of four individual wells from a single experiment; a total of four experiments were conducted with similar results. *Protein concentration decreased significantly compared to control $(\mathrm{p}<0.05)$. ${ }^{\#}$ Protein concentration decreased significantly compared to $1 \mathrm{nM} \mathrm{E}_{2}(\mathrm{p}<0.05)$. 


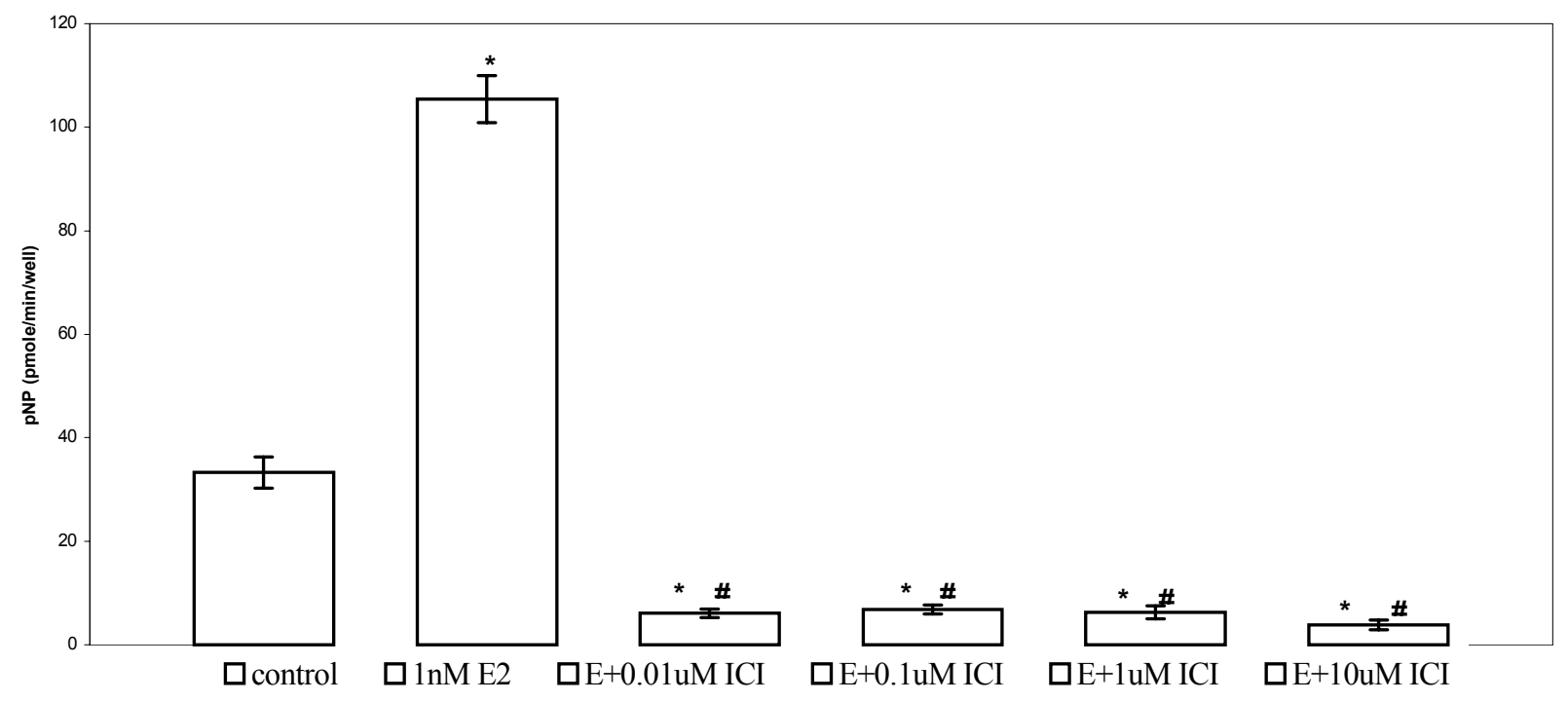

Fig.13. Anti-estrogen ICI 182,780 inhibits $E_{2}$-induced alkaline phosphatase activity in Ishikawa cells. Cells were plated in 96 -well plates and exposed to $1 \mathrm{nM} \mathrm{E}_{2}$, or a combination of $1 \mathrm{nM} \mathrm{E}_{2}$ and $0.01,0.1,1,10 \mu \mathrm{M}$ ICI 182,780 for 96 -hours, then assayed for alkaline phosphatase activity. Estradiol-induced alkaline phosphatase activity decreased significantly and below control levels in cells treated with combinations of $1 \mathrm{nM} \mathrm{E}_{2}$ and ICI 182,780; there was no significant difference in the activity between anti-estrogen treatment groups. Each point represents the mean \pm standard error of five individual wells from a single experiment; a total of four experiments were conducted with similar results. *Activity significantly different from control $(\mathrm{p}<0.05) .{ }^{\#}$ Activity decreased significantly compared to $1 \mathrm{nM} \mathrm{E}_{2}(\mathrm{p}<0.05)$. 


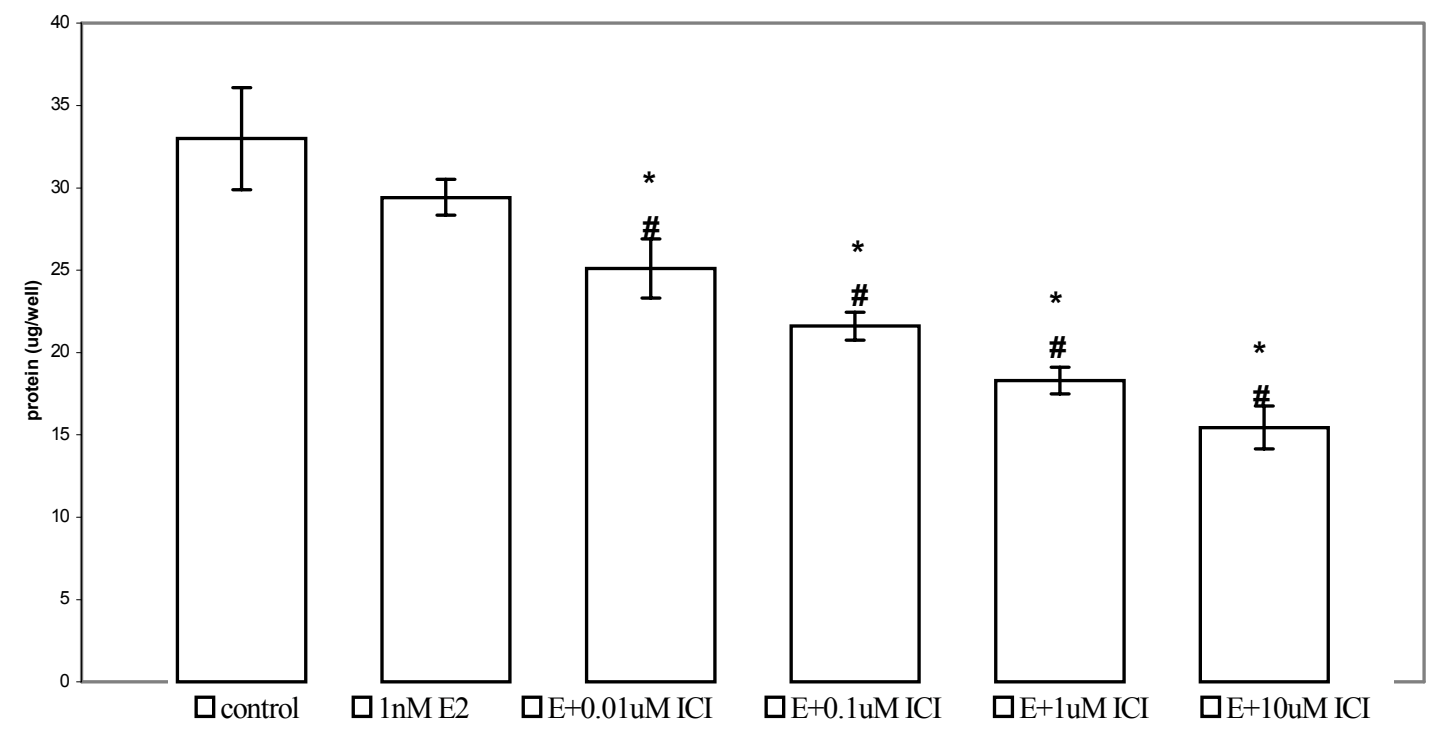

Fig.14. Anti-estrogen ICI 182,780 decreases total cellular protein concentrations in $\mathrm{E}_{2-}$ treated Ishikawa cells. Cells were plated in 96-well plates and exposed to $1 \mathrm{nM} \mathrm{E}_{2}$, or a combination of $1 \mathrm{nM} \mathrm{E}_{2}$ and $0.01,0.1,1$, or $10 \mu \mathrm{M}$ ICI 182,780 for 96 -hours, then assayed for total cellular protein by fluorescamine assay. Treatment with $1 \mathrm{nM} \mathrm{E}_{2}$ had no effect on cellular protein concentrations compared to control, however, 1nM E 2 plus $0.01,0.1,1,10 \mu \mathrm{M}$ ICI 182,780 significantly decreased protein in a concentration-dependent manner with increasing concentration of ICI 182,780 . * Protein concentration decreased significantly compared to control $(\mathrm{p}<0.05)$. ${ }^{\#}$ Protein concentration decreased significantly compared to $1 \mathrm{nM} \mathrm{E} \mathrm{E}_{2}(\mathrm{p}<0.05)$. 


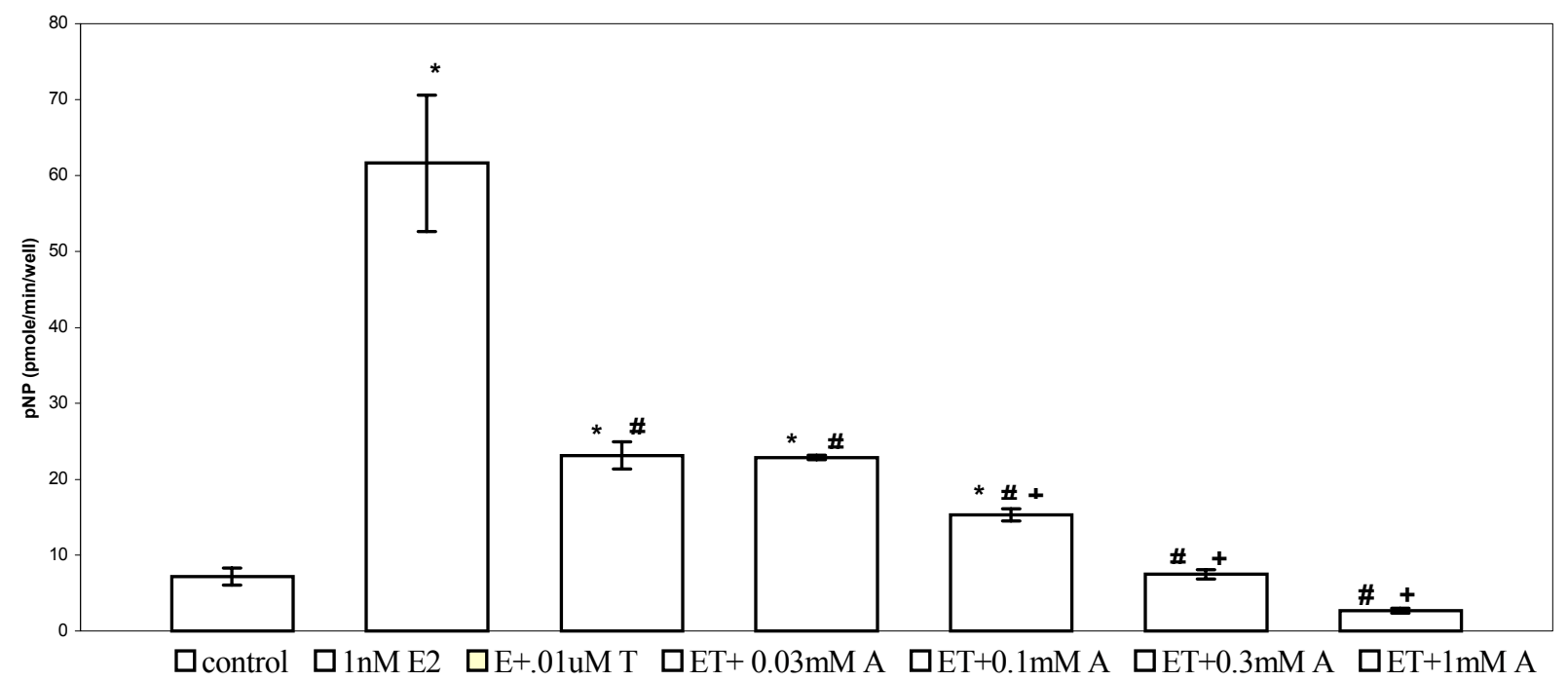

Fig.15. Acetaminophen (APAP) amplifies tamoxifen inhibition of $E_{2}$-induced alkaline phosphatase activity in Ishikawa cells. Cells were plated in 96-well plates and exposed to $1 \mathrm{nM}$ $\mathrm{E}_{2}, 1 \mathrm{nM} \mathrm{E}_{2}$ plus $0.01 \mu \mathrm{M}$ OHT, or combination of $1 \mathrm{nM} \mathrm{E}_{2}$ and $0.01 \mu \mathrm{M}$ OHT and $0.03,0.1,0.3$ or 1mM APAP for 96-hours, then assayed for alkaline phosphatase activity. Treatment with $1 \mathrm{nM} \mathrm{E}_{2}$ plus $0.01 \mu \mathrm{M} \mathrm{OHT}$ inhibited $\mathrm{E}_{2}$-induced alkaline phosphatase activity and this inhibition significantly increased with the addition of $0.1,0.3$ and $1 \mathrm{mM}$ APAP compared to $1 \mathrm{nM} \mathrm{E}_{2}$ plus $0.01 \mu \mathrm{M}$ OHT alone. *Activity significantly different from control $(\mathrm{p}<0.05) .{ }^{\#}$ Activity decreased significantly compared to $1 \mathrm{nM} \mathrm{E}_{2}(\mathrm{p}<0.05) .{ }^{+}$Activity decreased significantly compared to $1 \mathrm{nM}$ $\mathrm{E}_{2}+0.01 \mu \mathrm{M}$ OHT $(\mathrm{p}<0.05)$. 


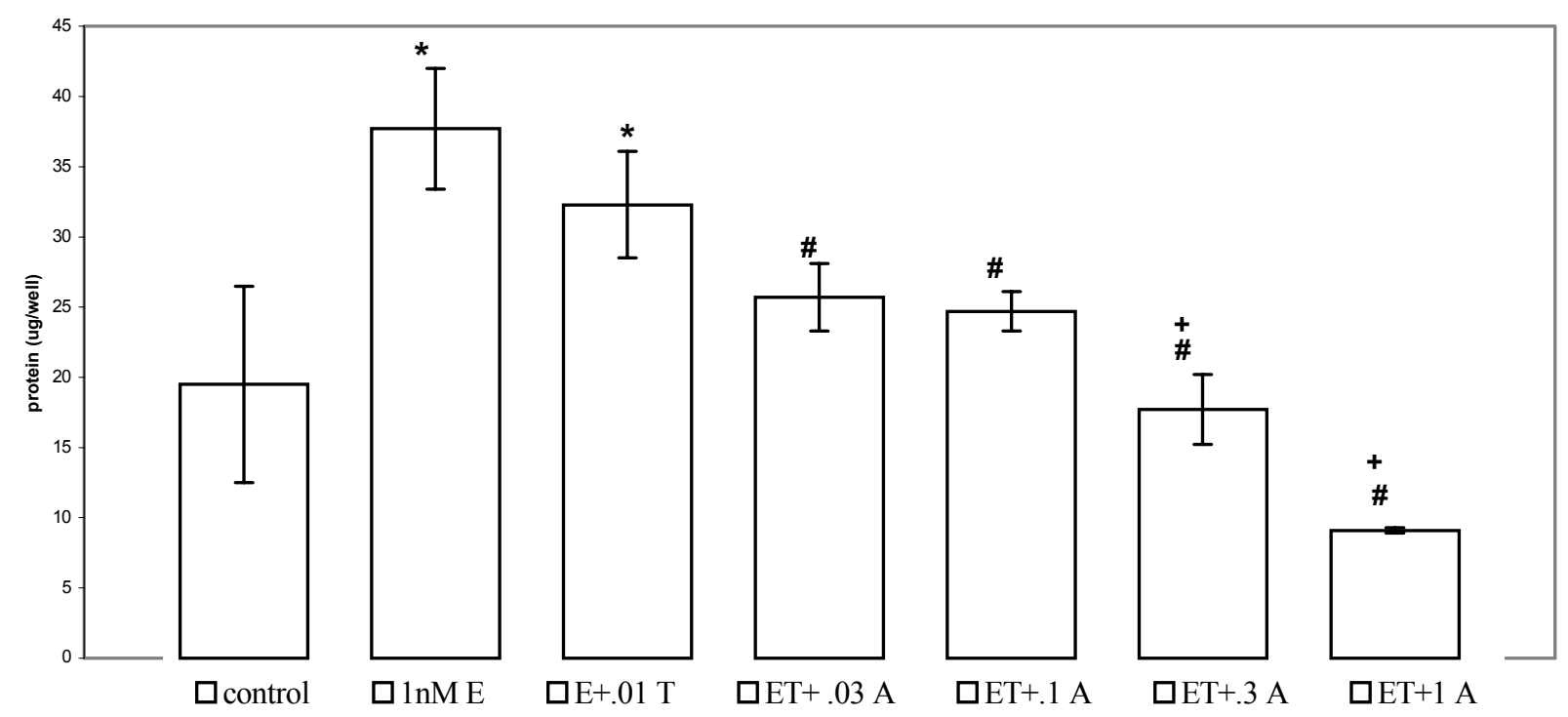

Fig.16. Acetaminophen (APAP) decreases total cellular protein concentrations in $\mathbf{E}_{2}-\mathrm{OHT}$

treated Ishikawa cells. Cells were plated in 96-well plates and exposed to $1 \mathrm{nM} \mathrm{E} \mathrm{E}_{2}, 1 \mathrm{nM} \mathrm{E}_{2}$ plus $0.01 \mu \mathrm{M}$ OHT, or combination of $1 \mathrm{nM} \mathrm{E}_{2}$ and $0.01 \mu \mathrm{M}$ OHT and $0.03,0.1,0.3$ or $1 \mathrm{mM}$ APAP for 96-hours, then assayed for total cellular protein by fluorescamine assay. Treatment with $1 \mathrm{nM} \mathrm{E}_{2}$ increased total cellular protein significantly compared to control; treatment with $1 \mathrm{nM} \mathrm{E}_{2}$ plus $0.01 \mu \mathrm{M}$ OHT increased total cellular proteins compared to control but was not significantly different than $\mathrm{E}_{2}$-treated cells. Treatment with $\mathrm{E}_{2}$ plus OHT and 0.3 or $1 \mathrm{mM}$ APAP decreased protein concentrations significantly below $\mathrm{E}_{2}$ plus OHT-treated cells. Each point represents the mean \pm standard error of four individual wells from a single experiment; a total of four experiments were conducted with similar results. *Protein concentration significantly different from control $(\mathrm{p}<0.05)$. ${ }^{\#}$ Protein concentration decreased significantly compared to $1 \mathrm{nM} \mathrm{E}_{2}$ $(\mathrm{p}<0.05) .{ }^{+}$Protein concentration decreased significantly compared to $1 \mathrm{nM} \mathrm{E}_{2}+0.01 \mu \mathrm{M}$ OHT $(\mathrm{p}<0.05)$ 

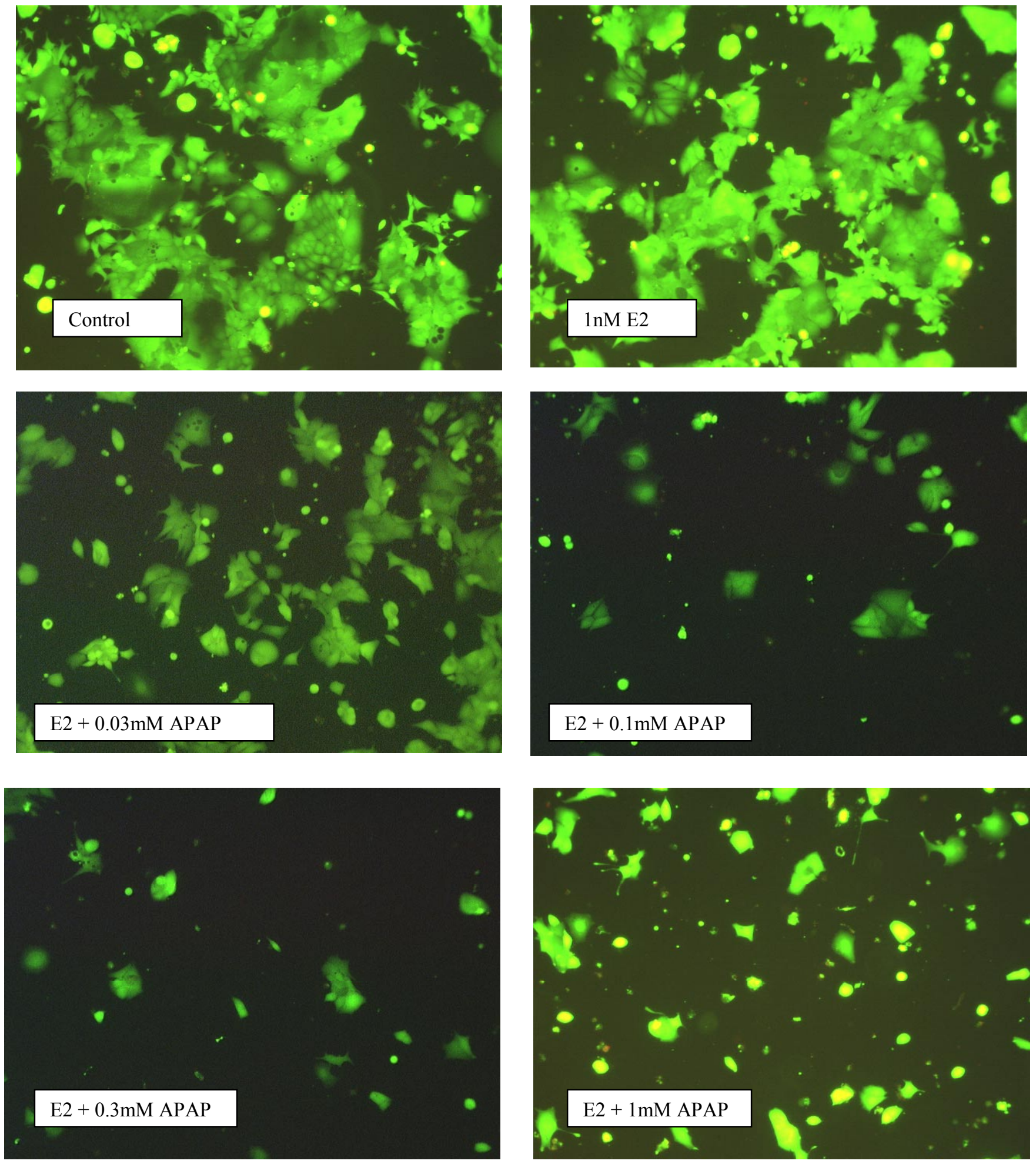
Fig.17. Calcein staining of Ishikawa shows morphological changes in response Acetaminophen (APAP) treatment. Cells were plated in 24-well plates and exposed to $\mathrm{E}_{2}$, and $\mathrm{E}_{2}$ plus $0.03,0.1,0.31 \mathrm{mM}$ APAP for 96-hours. Calcein (M) was added to each well and cells were examined using fluorescent microscopy with $80 \mathrm{X}$ magnification. Treatment with $\mathrm{E}_{2}$ had no visible effect; treatment with $\mathrm{E}_{2}$ plus $0.03,0.1 \mathrm{mM}$ APAP decreased size of clusters of cells; cells treated with $\mathrm{E}_{2}$ plus $0.3 \mathrm{mM}$ APAP appear misshapen; cells treated $\mathrm{E}_{2}$ plus $1 \mathrm{mM}$ APAP are no longer attached to plate indicating toxicity. 


\section{Discussion}

Acetaminophen (APAP) is currently being investigated as a possible endocrine disruptor due to its ability to alter estrogenic responses in vitro. At therapeutic concentrations, APAP induced cell proliferation in $\mathrm{ER}^{+} / \mathrm{PR}^{+} \mathrm{MCF}-7$ and T47D breast cancer cells and this effect was successfully inhibited by addition of antiestrogens; there was no induction of cell proliferation in $\mathrm{ER}^{-} / \mathrm{PR}^{-}$breast cancer cells (Harnagea-Theophilus et al., 1998). Another study demonstrated APAP inhiibted estrogen-dependent vitellogenin production in trout liver cells in vitro (Miller et al., 1999). However, most significant to human health issues are the case studies suggesting that APAP use is associated with decreased ovarian cancer incidence and alteration in hormone levels, including estrogen, in women who take the drug (Cramer ${ }_{\mathrm{a}, \mathrm{b}}$ et al., 1998).

The initial hypothesis was that APAP would induce estrogen-responsive alkaline phosphatase activity in Ishikawa endometrial cells based upon studies that indicate APAP has estrogen-like activity on cell proliferation in ER+/PR+ breast cancer cells (Harnagea-Theophilus et al., 1998). In order to test this hypothesis, Ishikawa cells were cultured in 96-well plates and exposed to $0.03,0.1,0.3$ or $1 \mathrm{mM}$ APAP for 96 -hours based upon the microtiter assay described by Littlefield et al. (1990). Acetaminophen concentrations were based upon those used in MCF-7 proliferation studies by Harnagea-Theophilus et al. (1998). Alkaline phosphatase activity and total cellular protein concentration were determined for APAP-treated cultures and controls. Total cellular protein was determined in addition to enzyme activity in order to have a variable comparable to enzyme activity; significant changes in protein concentration could be interrelated to increases in enzyme activity.

Acetaminophen decreased estrogen-responsive alkaline phosphatase activity in Ishikawa endometrial carcinoma cells, and thus the initial hypothesis was not borne out. Acetaminophen 
$(0.1,0.3$ and $1 \mathrm{mM})$ significantly inhibited basal and $1 \mathrm{nM} \mathrm{E}_{2}$-induced alkaline phosphatase activity; however, cellular protein concentrations were only inhibited by 0.3 and $1 \mathrm{mM}$ APAP alone or in combination with $1 \mathrm{nM} \mathrm{E}_{2}$. While the degree of enzyme inhibition was larger than the degree of protein decrease, these effects could have been the result of APAP toxicity. LDH release cytotoxicity assay was conducted to ensure that the decrease in alkaline phosphatase activity was not due to APAP toxicity. Ishikawa cells were exposed to $0.1,0.3,1,10$ or $20 \mathrm{mM}$ APAP for 24 and 96 hours and then assayed for LDH release. While toxicity was not detected at 24-hours, after 96-hours Ishikawa cells exposed to 1, 10 and 20mM APAP did release a considerable percentage of LDH thus indicating cytotoxicity.

Fluorescent microscopy results (Fig. 17) support the conclusion that 1mM APAP is toxic to Ishikawa cells; cells are visibly misshapen and unattached to the plate. This suggests that inhibition of alkaline phosphatase by $1 \mathrm{mM}$ APAP, with or without $1 \mathrm{nM} \mathrm{E}_{2}$, is likely due to APAP-toxicity. Cells exposed to $0.3 \mathrm{mM}$ APAP also had an increase in LDH release, but to a lesser degree than 1mM-treated cells while $0.1 \mathrm{mM}$ APAP had no effect on LDH release. Treatment with $0.3 \mathrm{mM}$ APAP significantly inhibited alkaline phosphatase activity and significantly decreased protein concentrations, observations that may be due to toxicity. Alkaline phosphatase inhibition by $0.1 \mathrm{mM}$ APAP was not accompanied by any effect on protein and cannot be correlated to any toxic effect of APAP. Therefore, the inhibitory effect of APAP on alkaline phosphatase activity may be due partially to toxicity at 0.3 , and $1 \mathrm{mM}$ APAP concentrations; however, there is still a level of inhibition that exists in cells treated with $0.1 \mathrm{mM}$ APAP that remains unexplained.

The next question to be addressed was a determination of any direct inhibition of alkaline phosphatase enzyme activity by APAP. Results of the alkaline phosphatase enzyme 
specific activity assay (Table 1) indicate that at the concentrations tested, APAP had no effect on enzyme activity compared to control. In conclusion, APAP inhibits basal and $\mathrm{E}_{2}$-induced alkaline phosphatase activity and this is not due to direct enzyme inhibition.

The second hypothesis determined if increasing concentrations of $E_{2}$ would decrease APAP inhibition of alkaline phosphatase activity. Cells were treated with $0.03,0.1,0.3$ or $1 \mathrm{mM}$ APAP plus either $0.01,0.1$ or $1 \mathrm{nM} \mathrm{E}_{2}$; samples were then assayed for alkaline phosphatase activity and cellular protein. Results (Table 2) show that APAP inhibition was not affected by different concentrations $E_{2}$. The level of inhibition by a single concentration of APAP was not significantly changed when estradiol was increased 10 or even 100 -fold; protein concentrations were unaffected under the same conditions. There were no signs of competitive inhibition by APAP on $E_{2}$-induced alkaline phosphatase activity. The results from this inhibition study are in agreement with studies that indicate APAP does not compete with $\mathrm{E}_{2}$ for binding at ER (Miller et al., 1999; Isenhower et al., 1986; Harnagea-Theophilus ${ }_{\mathrm{a}}$ et al., 1999).

Interestingly, cells treated with $0.01 \mathrm{nM} \mathrm{E}_{2}$ plus 0.03 or $0.1 \mathrm{nM}$ APAP had a stimulatory effect and significantly increased alkaline phosphatase activity compared to $0.01 \mathrm{nM} \mathrm{E}_{2}$ alone. This effect was seen in 3 of the four experiments conducted and there were no changes cellular protein, suggesting that APAP may have some partial-agonist activity when combined with $0.01 \mathrm{mM} \mathrm{E}_{2}$.

In the $\mathrm{E}_{2}$-APAP inhibition study (Table 3) it appears that APAP had less of an inhibitory effect upon $1 \mathrm{nM} \mathrm{E}_{2}$-induced alkaline phosphatase activity than indicated in initial studies (Fig. 7). This is a result of expressing the data as a mean of four experiments rather than showing a single representative experiment. There was some variation in the magnitude of response in both alkaline phosphatase and protein concentration within the four experiments conducted. 
Variability resulted from Ishikawa cells being cultured in estradiol-free medium for a minimum of two weeks prior to an experiment in order to achieve low basal levels of alkaline phosphatase activity. Cells were viable for a period of approximately six-weeks under estrogen-free conditions, and had the highest levels of enzyme activity and protein concentration after the initial two-week staging period. Maximal activity and protein concentration in response to $\mathrm{E}_{2}$ declined slightly with time; however, the relative percent of inhibition by APAP did not change. This is indicated by relatively low standard error between experiments (Table 3).

Based upon the inhibitory effect of APAP on alkaline phosphatase determined in prior experiments, the final hypothesis of this study tested the ability of APAP to increase the inhibitory effect of antiestrogens on alkaline phosphatase activity in Ishikawa cells. Antiestrogen ICI 182,780, a type I pure antiestrogen, has been shown to inhibit $1 \mathrm{nM} \mathrm{E}_{2}$-induced alkaline phosphatase activity in a concentration-dependent manner (Markiewicz et al., 1997); however, in the present study $0.01-10 \mu \mathrm{M}$ ICI 182,780 significantly inhibited $\mathrm{E}_{2}$-induced alkaline phosphatase activity below controls levels (Fig. 13) and was therefore deemed unsuitable for this study.

4-Hydroxy tamoxifen is a type II antiestrogen with partial agonist activity in Ishikawa cells, although published reports are not consistent at this point. While some studies indicate that OHT alone weakly stimulates alkaline phosphatase activity (Simard et al., 1997; Anzai et al., 1989, Markiweicz et al., 1997), cell growth (Anzai et al., 1989), and significantly inhibits $\mathrm{E}_{2}$ induced alkaline phosphatase activity (Simard et al., 1997; Holinka et al., 1986; Markiweicz et al., 1997), another study (Albert et al., 1990) found that OHT had no effect on basal or $\mathrm{E}_{2}$ induced alkaline phosphatase activity. 
Results (Fig. 11) show that OHT alone decreased alkaline phosphatase activity $~ 50 \%$ at $0.01,0.1$ and $1 \mu \mathrm{M}$; cellular protein concentrations were unaffected; however, at $10 \mu \mathrm{M} \mathrm{OHT}$ both alkaline phosphatase activity and protein concentrations were absent apparently due to toxicity. As hypothesized, APAP increased OHT inhibition of $\mathrm{E}_{2}$-induced alkaline phosphatase activity (Fig. 15). While addition of $0.03 \mathrm{APAP}$ to $1 \mathrm{nM} \mathrm{E}_{2}$ plus $1 \mu \mathrm{M}$ OHT had no effect (which agrees with previous data), addition of $0.1,0.3$ and 1mM APAP significantly increased inhibition of alkaline phosphatase activity in a concentration-dependent manner compared to $\mathrm{E}_{2}$ plus OHT alone. Cellular protein levels were significantly decreased only in cells treated with $\mathrm{E}_{2}$ plus OHT and $0.3,1 \mathrm{mM}$ APAP. This study indicates that APAP potentiates the inhibitory effect of antiestrogen OHT.

In summary, 0.01, 0.3 and $1 \mathrm{mM}$ APAP inhibits both basal and $\mathrm{E}_{2}$-induced alkaline phosphatase activity in Ishikawa endometrial cells. In combination with antiestrogen OHT, APAP further inhibits $\mathrm{E}_{2}$-induced alkaline phosphatase activity. Cellular protein is significantly decreased in cells treated with 0.3 and $1 \mathrm{mM}$ APAP alone, in combination with $1 \mathrm{nM} \mathrm{E}_{2}$, or $1 \mathrm{nM}$ $\mathrm{E}_{2}$ plus $1 \mu \mathrm{M}$ OHT. As determined by $\mathrm{LDH}$ release, APAP is toxic at $1 \mathrm{mM}$, to a lesser degree at $0.5 \mathrm{mM}$ and not at all at 0.25 compared to control. Therefore, alkaline phosphatase activity inhibition by $1 \mathrm{mM}$ APAP may be in part due to APAP-toxicity, but inhibition by 0.3 and $0.1 \mathrm{mM}$ APAP is not due to toxicity. APAP has no inhibitory effect on the specific activity of $E_{2}$-induced alkaline phosphatase.

The mechanism by which APAP inhibits alkaline phosphatase activity is unknown. Estrogen induction of alkaline phosphatase enzyme activity in Ishikawa cells occurs via the classical ER mediated pathway (Fig.18). Acetaminophen does not appear to be acting through a traditional antiestrogenic mechanism as it does not compete with estradiol for binding at the ER 
(Miller et al., 1999; Isenhower et al., 1986; Harnagea-Theophilus $\mathrm{a}_{\mathrm{a}}$ et al., 1999) or inhibit enzyme activity directly. The fact that both basal and $\mathrm{E}_{2}$-inducible alkaline phosphatase enzyme activity is inhibited suggests that APAP may be targeting the transcription or the translational processes. This study did not address the question of the effect of APAP on the specific isozymes of alkaline phosphatase. Acetaminophen inhibits estradiol-responsive alkaline phosphatase (Fig. 5), but in addition, most likely inhibits the other isotypes as reflected in the inhibition of basal enzyme activity under serum-free (estrogen-free) conditions (Fig.7).

A recent study demonstrated that aryl hydrocarbon receptor agonists inhibited estrogeninduced responses through AhR-ER crosstalk in Ishikawa cells (Wormke et al., 2000). The aryl hydrocarbon receptor is known to be involved in the metabolism of xenobiotics; no endogenous ligand has been identified. The AhR contains several transactivational domains that mediate ligand-recognition/binding, DNA binding, AhR nuclear transport protein (ARNT) binding, as well as cell-specific inhibitory protein binding domain (Ma Q et al., 1997). In target cells AhR agonists, such as TCCD, bind the aryl hydrocarbon receptor and then complex with AhR nuclear transport proteins while accumulating in the nucleus of the cell (Fig. 19). This complex binds dioxin response elements (DREs), also known as xenobiotic response elements (XREs), and results in transcription of genes involved in drug and hormone metabolism such as cytochrome P4501A1 (CYP1A1), CYP1B1, GST, A2 and NADPH quinone reductase (Klinge et al., 1999). Although the AhR-ARNT complex does not bind consensus estrogen-response elements, the complex does bind naturally occurring EREs that contain XRE-like sequences, such as human cfos, $\mathrm{pS} 2$, and progesterone receptor gene promoter regions (Klinge et al., 1999). In transiently transfected MCF-7 breast cancer cells, TCDD inhibited $\mathrm{E}_{2}$-activated reporter gene activity from both consensus EREs and EREs from c-fos, pS2, and progesterone receptor genes (Klinge et al., 
1999). This antiestrogenic activity by TCDD and other polycyclic hydrocarbon compounds is termed AhR-ER crosstalk. TCDD and other AhR ligands do not bind the ER or displace $\mathrm{E}_{2}$ from its receptor in ligand-binding studies (Klinge et al., 1999); however, unbound AhR directly interacts with ER $\alpha$ (Klinge et al., 2000). The AhR has no interaction with ER $\beta$ and complexed AhR/ARNT has no interaction with the ER $\alpha$ or $\beta$ (Klinge et al., 2000). While the underlying mechanism behind AhR-ER crosstalk is not completely understood, studies indicate that there is direct interaction between the AhR and ER-mediated responses.

A recent study by Wormke et al. (2000) confirms that both AhR and ARNT protein are expressed in Ishikawa cells. Inhibitory AhR-ER crosstalk was determined using $\mathrm{E}_{2}$-induced proliferation and transcriptional assays in Ishikawa cells transfected with $\mathrm{E}_{2}$-responsive constructs using promoters from the progesterone receptor or vitellogenin A2 genes. Aryl hydrocarbon receptor agonists, 2,3,7,8-tetrachlorodibenzo-p-dioxin (TCDD), benzo[a]pyrene (BaP) and 6-methyl-1,3,8-trichlorodeibenzofuran, inhibited $32-47 \%$ of the $\mathrm{E}_{2}$-induced responses (Wormke et al., 2000). A second study using ECC-1 endometrial cancer cells, which express $\mathrm{ER} \alpha$ and $\mathrm{AhR}$, found that treatment with TCCD also inhibited $\mathrm{E}_{2}$-induced cell proliferation (Castro et al., 1999). While TCDD inhibited $\mathrm{E}_{2}$-enhanced procathespin D secretion in PE04 $\mathrm{ER}^{+}$ human ovarian cancer cells and Hep-1 cells (Rowlands et al., 1993; Kharat et al., 1996), in mutant Hep-1 cells deficient in functional AhR, TCCD was no longer inhibitory on estrogeninducible genes (Kharat et al., 1996).

The results of the present study may be due to APAP binding the AhR resulting in inhibitory effects on $\mathrm{E}_{2}$-responsive alkaline phosphatase activity in Ishikawa cells via an interaction through AhR-ER crosstalk. Although the ERE for placental alkaline phosphatase in Ishikawa cells has not been defined as a classical ERE, it is possible that placental alkaline 
phosphatase, an estrogen-responsive gene, contains an XRE-like sequence. Binding of the AhRAPAP complex to the XRE-like sequence of the promoter region of the alkaline phosphatase gene would block the ER from binding the ERE. This might explain the non-competitive inhibition of $E_{2}$-induced alkaline phosphatase activity and the inhibition of basal enzyme activity as well. In addition, this AhR-APAP complex could bind and inhibit other genes containing XRE-like sequences resulting in decreased cellular protein and possibly result in cell toxicity. This hypothesis also can be extended to APAP's ability to induce cell proliferation in $\mathrm{ER}+/ \mathrm{PR}+\mathrm{MCF} 7$ cells and inhibition of estrogen-dependent vitellogenin in trout liver cells. Perhaps the APAP-AhR interferes with cell cycle-regulating protein in MCF7 cells; estrogendependent vitellogenin could have an XRE-like sequence in its ERE.

\section{Significance}

This study shows that APAP interferes with expression of estrogen-responsive genes in Ishikawa endometrial carcinoma cells. Even more significant was the inhibitory effect on estrogen-responsive alkaline phosphatase in Ishikawa cells compared to previous studies showing stimulation of estrogen-responsive cell proliferation in MCF-7 human breast cancer cells. Questions brought about by this study are two-fold: what is the mechanism behind APAP inhibition of alkaline phosphatase in Ishikawa cells; why does APAP have different responses in different cell types?

Ishikawa cells are a good model of estrogen-responsive cells and are currently being used commercially as an in vitro estrogen-screen tool. The alkaline phosphatase assay is a simple and inexpensive assay that can be used to screen multiple samples at a time by the microplate method; however, the usefulness of estrogen screening by Ishikawa cells is limited and should be 
used as an initial indicator of potential estrogenic activity. Since in vitro studies do not address questions such as metabolism and bioavailability of active compounds or their metabolites, further investigation is necessary. Whole animal and human case studies need to be utilized to determine actual estrogenic potential of any compound as it relates to human health. 


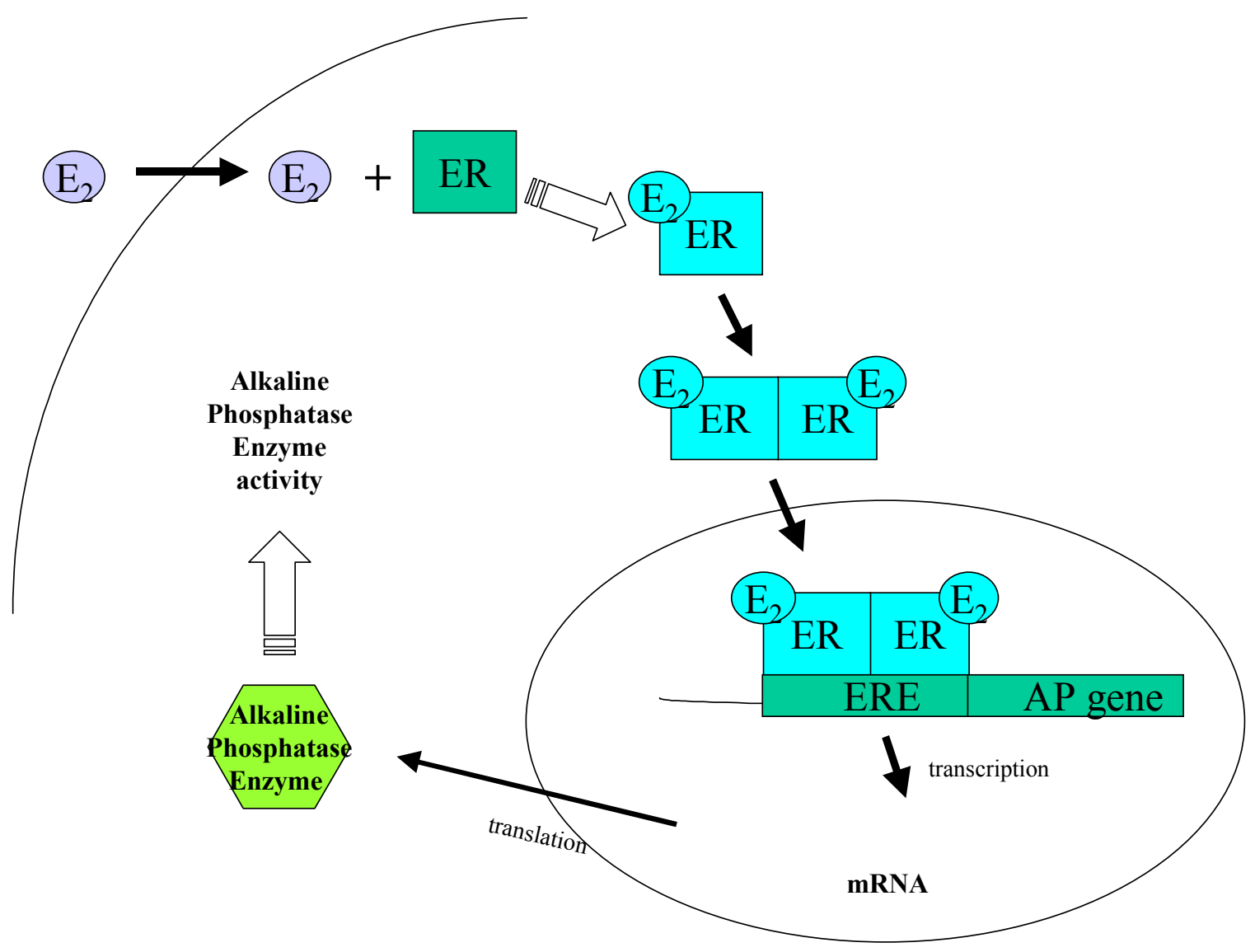

Fig.18. Estrogen Receptor Mediated Gene Transcription of Alkaline Phosphatase and Acetaminophen interaction. The site of action of acetaminophen on alkaline phosphatase-induction by estradiol is unknown. Large striped arrows indicate places where APAP is believed not to be acting: at the ER binding site of E2; direct interaction with the enzyme inhibiting activity. Smaller arrows indicate places where APAP could be interfering with the pathway of estradiol-induction of alkaline phosphatase. 


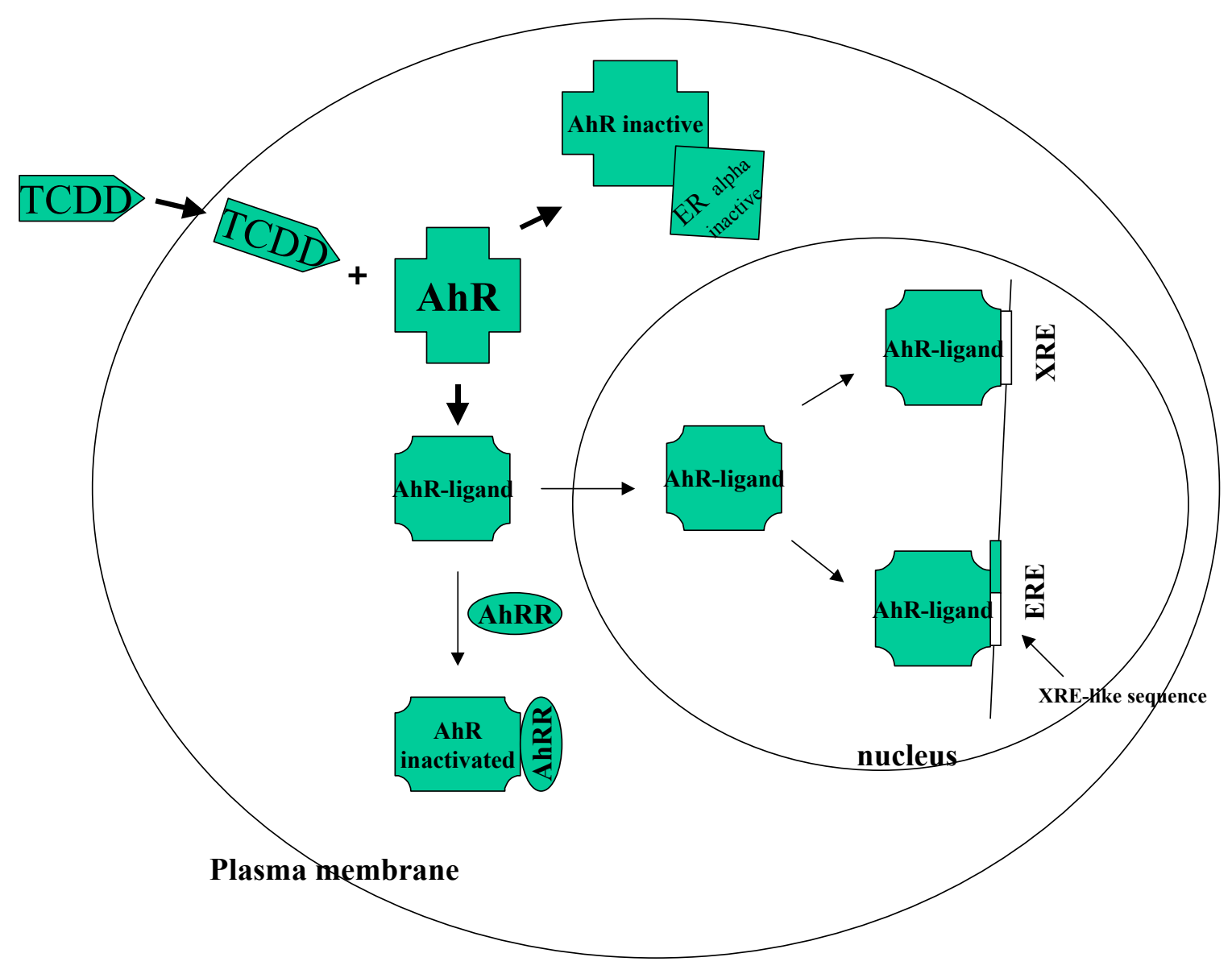

Fig 19. Aryl Hydrocarbon Receptor Mediated Gene Inhibition of Estrogen-Inducible

Genes. TCDD, or other AhR agonist, enters the cell where it binds AhR. This complex binds to ARNTS (not depicted) as it enters the nucleus. The activated AhR-AARNT complex binds to xenosterogen/dioxin response elements (XRE) and also can bind EREs containing XRE-like sequences. AhR binding to EREs block activated estrogen receptor binding inhibiting transcription. Unbound AhR can bind inactive ER $\alpha$ in the cytosol leading to inhibition of ER activity. AhR-induced aryl hydrocarbon repressor (AhRR) binds AhR and serves as a selfregulatory mechanism. 


\section{Future Studies}

Studies by Barkhem et al. (1998) indicate that OHT, raloxifene and ICI 164,384 have an ER $\alpha$-selective partial agonist/antagonist activity, but act as pure antagonists through ER $\beta$. Although there have been two subtypes of ER characterized in Ishikawa cells (Kd. 0.2 and 0.6nM), these two ER subtypes have not been positively identified or quantified (Kassan et al., 1989). Western blot using specific antibodies could identify ER subtypes $\alpha$ and $\beta$ present in Ishikawa cells. Identification of subtypes in Ishikawa cells may also shed some light on why APAP has antagonist activity on alkaline phosphatase activity in Ishikawa cells, yet had estrogen-like activity in ER+/PR+ breast cancer cell proliferation studies. Differences in the presence of ER subtypes may be the reason behind the agonist or antagonist activity of APAP in particular cell types.

Crosstalk between ER and AhR in Ishikawa cells, through APAP interaction with the AhR, is also a possible mechanism that would produce inhibition of estrogen-responsive genes. A recent study by Wormke et al. (2000) has shown that AhR and its associated proteins are expressed in Ishikawa cells. Treatment with TCDD and other AhR agonists inhibited $\mathrm{E}_{2}$-induced responses such cell proliferation and transcriptional activation assays (Wormke et al., 2000). Future experiments should be aimed at determining if APAP binds AhR in ligand-binding assays and if TCDD inhibits alkaline phosphatase activity in Ishikawa cells.

It is also unclear if APAP is specifically targeting an estrogen-responsive gene or perhaps just targeting regulation of alkaline phosphatase. To answer this question other estrogenresponsive genes in Ishikawa cells such as progesterone receptor induction and cell proliferation could be examined. If APAP were acting through an ER-mediated pathway then inhibition of these estrogen-regulated processes would be expected. To answer the question of APAP 
specificity for alkaline phosphatase, T47D breast cancer cells could be used since the alkaline phosphatase activity expressed in that cell line is progesterone-induced and estrogenunresponsive (Di Lorenzo et al., 1991). The expected results would be no change in enzyme activity with APAP treatment in T47D cells.

This study has evoked many questions and directions for future studies in the area of APAP and its interaction with estrogen-responsive genes in vitro. The studies suggested would enhance the understanding of ER-responsive gene regulation in estrogen-sensitive cells, as well as the many different possible mechanisms involved in the inhibitory process. 


\section{Literature Cited}

Albert, J.L., Sundstrom, S.A., Lyttle, C.R. (1990) Estrogen regulation of placental alkaline phosphatase gene expression in a human endometrial adenocarcinoma cell line. Cancer Res. Jun 1;50(11):3306-10.

Anzai, Y., Holinkam C.F., Kuramoto, H., Gurpide, E. (1989) Stimulatory effects of 4hydroxytamoxifen on proliferation of human endometrial adenocarcinoma cells (Ishikawa line) Cancer Res. May 1;49(9):2362-5.

Arnold, S.F., Vonier, P.M., Collins, B.M., Klotz, D.M., Guillette, L.J. Jr. and McLachlan, J.A. (1997) In vitro synergistic interaction of alligator and human estrogen receptors with combinations of environmental chemicals. Environ Health Perspect. 105 (3):615-8.

Barkhem, T., Carlsson, B., Nilsson, Y., Enmark, E., Gustafsson, J., Nilsson, S., (1998) Differential response of estrogen receptor alpha and estrogen receptor beta to partial estrogen agonists/antagonists. Mol. Pharmacol. Jul;54(1):105-12.

Barsalou, A., Gao, W., Anghel, S.I., Carriere, J., Mader, S. (1998) Estrogen response elements can mediate agonist activity of anti-estrogens in human endometrial Ishikawa cells. $J$ Biol Chem. Jul 3;273(27):17138-46.

Beyer, C. (1999) Estrogen and the developing mammalian brain. Anat Embryol 199(5):379-90.

Blake, C.A., Boockfor, F.R. (1997) Chronic administration of the environmental pollutant 4-tertoctylphenol to adult male rats interferes with the secretion of luteinizing hormone, follicle-stimulating hormone, prolactin, and testosterone. Biol Reprod. Aug;57(2):255-66.

Boockfor, F.R. and Blake, C.A. (1997) Chronic administration of 4-tert-octylphenol to adult male rats causes shrinkage of the testes and male accessory sex organs, disrupts spermatogenesis, and increases the incidence of sperm deformities. Biol Reprod. 57(2):267-77.

Boss, W.R. and Witschi, E. (1947) The permanent effects of early stilbesterol injections on the sex organs of the herring gull (Larus argentatus). J. Exp. Zool. 105:61-77.

Boyd, E.M. (1970) Testicular atrophy from analgesic drugs. J Clin Pharmacol. JulAug;10(4):222-7.

Bradford, M.M. (1976) A rapid and sensitive method for the quantitation of microgram quantities of protein utilizing the principle of protein-dye binding. Anal Biochem, May $7 ; 72: 248-54$.

Brasso, K. and Iverson, P. (1999) Prostate cancer in Denmark. Incidence, morbidity and mortality. Scand J Urol Nephrol Suppl. ;203:29-33. 
Bryan, T.E., Gildersleeve, R.P., Wiard, R.P. (1989) Exposure of Japanese quail embryos to o,p'DDT has long-term effects on reproductive behaviors, hematology, and feather morphology. Teratology 39(6):525-35.

Bulger, W.H., Muccitelli, R.M., Kupfer, D. (1978) Studies on the in vitro and in vivo estrogenic activities of methoxychlor and its metabolites. Role of hepatic mono-oxygenase in methoxychlor activation. Biochem. Pharmacol 27:2417-23.

Bull, J.J. (1980) Sex determination in reptiles. Q. Rev. Biol. 55:3-21.

Cade, T.J., Lincer, J.L., White, C.M., Roseneau, D.G., Swartz, L.G. (1971) DDE residues and eggshell changes in Alaskan falcons and hawks. Science 172:955-957.

Castro-Rivera, E., Wormke, M., Safe, S. (1999) Estrogen and aryl hydrocarbon responsiveness of ECC-1 endometrial cancer cells. Mol. Cell Endocrinol. Apr 25;150(1-2):11-21.

Compton, S.J. and Jones, C.G., (1985) Mechanism of dye response and interference in the Bradford protein assay. Anal Biochem. Dec;151(2):369-74.

Cooper, K. (1991)Effects of Pesticides on wildlife. In: Handbook of pesticide toxicology, vol. 1 (Hayes, W.J. and Laws, E.R., eds.) New York Academic Press :463-95.

Cramer a, D.W., Harlow, B.L., Titus-Ernstoff, L., Bohlke, K., Welch, W.R., Greenberg, E.R. (1998) Over-the-counter analgesics and risk of ovarian cancer. Lancet Jan 10;351(9096):104-7.

Cramer $_{b}$, D.W., Liberman, R.F., Hornstein, M.D., McShane, P., Powers, D., Li, E.Y., Barbieri, R. (1998) Basal hormone levels in women who use acetaminophen for menstrual pain. Fertil Steril. Aug;70(2):371-3.

Crews, D., Bergeron, J.M., McLachlin, J.A. (1995) The role of estrogen in turtle sex determination and the effect of PCBs. Environ Health Perspect. 103(7):73-7.

Cromartie, E., Reichel, W.L., Locke, L.N., Belisle, A.A., Kaiser, T.E., Lamont, T.G., Mulhern, B.M., Prouty, R.M., Swineford, D.M. (1975) Residues of organochlorine pesticides and polychlorinated biphenyls and autopsy data for bald eagles, 1971-1972. Pestic Monit. J. 9:11-14.

Cunningham, A.R., Klopman, G., Rosenkranz, H.S. (1997) A dichotomy in the lipophilicity of natural estrogens, xenoestrogens, and phytoestrogens. Environ Health Perspect. Apr;105 Suppl 3:665-8.

Dahlin, D.C., Miwa, G.T., Lu, A.Y., Nelson, S.D. (1984) N-acetyl-p-benzoquinone imine: a cytochrome P-450-mediated oxidation product of acetaminophen. Proc Natl Acad Sci US A. Mar;81(5):1327-31. 
Dai, Y. and Cederbaum, A. J. (1995) Cytotoxicity of acetaminophen in human cytochrome P4502E1-transfected HepG2 cells. Pharmacol Exp Ther. Jun;273(3):1497-505.

Dennis, L.K., and Resnick, M.I. (2000) Analysis of recent trends in prostate cancer incidence and mortality. Prostate. Mar 1;42(4):247-52.

Di Lorenzo, D., Albertini, A., Zava, D. (1991) Progestin regulation of alkaline phosphatase in the human breast cancer cell line T47D. Cancer Res. Aug 15;51(16):4470-5.

Dorgan, J.F., Brock, J.W., Rothman, N., Needham, L.L., Miller, R., Stephenson, H.E. Jr., Schussler, N., Taylor, P.R. (1999) Serum organochlorine pesticides and PCBs and breast cancer risk: results from a prospective analysis (USA). Cancer Causes Control 10(1):111.

Dukes, M.N.G.; Chapter 40.2 Sex Hormones; Meyler's Side Effects of Drugs $13^{\text {th }}$ edition (1996) (B. Hovac ed.) p.1249.

Fein, G.G., Jacobson, J.L., Jacobson, S.W., Schwartz, P.M., Dowler, J.K. (1984) Prenatal exposure to polychlorinated biphenyls: effects on birth size and gestational age. $J$ Pediatr 105(2):315-20.

Frohlander, N. and Millan, J.L. (1991) Alkaline phosphatases as reporters of developmental and cancerous events. In Vivo. Sep-Oct;5(5):483-8.

Fry, D.M. and Toone, C.K. (1981) DDT-induced feminization of gull embryos. Science 213:92224.

Fry, D.M., Toone, C.K., Tone C.K., Speich, S.M., Pearl, R.J. (1987) Sex skew ratio and breeding patterns of gulls demographic and toxicological considerations. Stud Avian Biol. 10:2643.

Fry, D.M. (1995) Reproductive effects in birds exposed to pesticides and industrial chemicals. Environ Health Perspect. 103(7):165-71.

Garry, V.F., Schreinemachers, D., Harkins, M.E., Griffith, J. (1996) Pesticide appliers, biocides, and birth defects in rural Minnesota. Environ. Health Perspect. 104(4):394-9.

Ghosh, N. K. and Fishman, W.H. (1968) Purification and properties of molecular-weight variants of human placental alkaline phosphatase. Biochem J Aug;108(5):779-92.

Giwercman, A., Carlsen, E., Keiding, N., Skakkebaek, N.E. (1993) Evidence for increasing incidence of abnormalities of the human testis: a review. Environ Health Perspect. Jul;101 Suppl 2:65-71.

Gray, L.E. Jr. and Kelce, W.R. (1996) Latent effects of pesticides and toxic substances on sexual differentiation of rodents. Toxicol. Appl. Pharmacol 12(3-4):515-31. 
Gray, L.E., Jr., Wolf, C., Lambright, C., Mann, P., Price, M., Cooper, R.L., Ostby, J. (1999) Administration of potentially antiandrogenic pesticides (procymidone, linuron, iprodione, chlozolinate, p,p'-DDE, and ketoconazole) and toxic substances (dibutyl- and diethylhexyl phthalate, PCB 169, and ethane dimethane sulphonate) during sexual differentiation produces diverse profiles of reproductive malformations in the male rat. Toxicol Ind Health. Jan-Mar;15(1-2):94-118.

Greenwood, A.W., Blyth, J.S.S. (1938) Experimental modification of the accesory sexual aparatus in the hen. Q.J. Exp. Physiol. 28:61-69.

Guillette, L.J. Jr., Gross, T.S., Masson, G.R., Matter, J.M., Percival, H. F., Woodward, A. R. (1994) Developmental abnormalities of the gonad and abnormal sex hormone concentrations in juvenile alligators from contaminated and control lakes in Florida. Environ Health Perspect. 102(8):157-64.

Guillette a, L.J. Jr., Crain, D.A., Rooney, A.A., Pickford, D.B. (1995) Organization versus activation: the role of endocrine-disrupting contaminants (EDCs) during embryonic development in wildlife. Environ Health Perspect 103(7):157-64.

Guillette $_{\text {, }}$ L.J. Jr., Gross, T.S., Gross, D.A., Rooney, A.A., Percival, H.F. (1995) Gonadal steroidogenesis in vitro from juvenile alligators obtained from contaminated or control lakes. Environ Health Perspect. 103(4):31-6.

Guillette, L.J. Jr., Pickford, D.B., Crain, D.A., Rooney, A.A., Percival, H.F. (1996) Reduction in penis size and plasma testosterone concentrations in juvenile alligators living in a contaminated environment. Gen Comp Endocrinol. 101(1):32-42.

Guillette, L.J. Jr., Brock, J.W., Rooney, A.A., Woodward, A.R. (1999) Serum concentrations of various environmental contaminants and their relationship to sex steroid concentrations and phallus size in juvenile American alligators. Arch Environ Contam Toxicol. 36(4):447-55.

Guttes, S., Failing, K., Neumann, K., Kleinstein, J., Georgii, S., Brunn, H. (1998) Chlororganic pesticides and polychlorinated biphenyls in breast tissue of women with benign and malignant breast disease. Arch. Environ. Contam. Toxicol. 35(1):140-7.

Harnagea-Theophilus, E. and Miller, M.R. (1998) Acetaminophen alters estrogenic responses in vitro: stimulation of DNA synthesis in estrogen-responsive human breast cancer cells. Toxicol. Sci. 46(1):38-44.

Harnagea-Theophilusa, E., Gadd, S.L., Knight-Trent, A.H., DeGeorge, G.L., Miller, M.R. (1999) Acetaminophen-induced proliferation of breast cancer cells involves estrogen receptors. Toxicol. Appl. Pharmacol.155(3):273-9. 
Harnagea-Theophilus $b$, E., Miller, M.R., Rao, N. (1999) Positional isomers of acetaminophen differentially induce proliferation of cultured breast cancer cells. Toxicol Lett. Jan $11 ; 104(1-2): 11-8$.

Hata, H. and Kuramoto, H. (1992) Immunocytochemical determination of estrogen and progesterone receptors in human endometrial adenocarcinoma cells (Ishikawa cells). $J$ Steroid Biochem Mol Biol. Apr;42(2):201-10.

Heinz, G.H., Percival, H.F., Jennings, M.L., (1991) Contaminants in American alligator eggs from lakes Apopka, Griffin and Okeechobee, Florida. Environ. Monit. Assess. 16:277-85.

Helzlsouer, K.J., Alberg, A.J., Huang, H.Y., Hoffman, S.C., Strickland, P.T., Brock, J.W., Burse, V.W. Needham, L.L., Bell, D.A., Lavigne, J.A., Yager, J.D., Comstock, G.W. (1999) Serum concentrations of organochlorine compounds and the subsequent development of breast cancer. Cancer Epidemiol Biomarkers Prev. 8(6):525-32.

Henthorn, P., Zervos, P., Raducha, M., Harris, H., Kadesch, T. (1988) Expression of a human placental alkaline phosphatase gene in transfected cells: use as a reporter for studies of gene expression. Proc Natl Acad Sci USA. Sep;85(17):6342-6.

Hill, G.B., Burns, P.E., Koch, M., Lees, A.W., Starreveld, A.A. (1983) Trends in the incidence of cancer of the female breast and reproductive tract in Alberta, 1953 to 1977. Prev Med. Mar;12(2):296-303.

Hinson, J.A. (1980) Biochemical toxicology of acetaminophen. Rev. Biochem. Toxicol. 2. 1:03129.

Hinson, J.A., Pumford, N.R., Roberts, D.W. (1995) Mechanisms of acetaminophen toxicity: immunochemical detection of drug-protein adducts. Drug Metab Rev. 27(1-2):73-92.

Hoivik, D., Willett, K., Wilson, C., Safe, S. (1997) Estrogen does not inhibit 2,3,7, 8tetrachlorodibenzo-p-dioxin-mediated effects in MCF-7 and Hepa 1c1c7 cells. J. Biol. Chem. Nov 28;272(48):30270-4.

Holinka $_{\mathrm{a}}$, C.F., Hata, H., Gravanis, A., Kuramoto, H., Gurpide, E. (1986) Effects of estradiol on proliferation of endometrial adenocarcinoma cells (Ishikawa line). J Steroid Biochem. Nov;25(5B):781-6.

Holinka $_{b}$, C.F., Hata, H., Kuramoto, H., Gurpide, E. (1986) Effects of steroid hormones and antisteroids on alkaline phosphatase activity in human endometrial cancer cells (Ishikawa line). Cancer Res. Jun;46(6):2771-4.

Holinka, C.F., Anzai, Y., Hata, H., Kimmel, N., Kuramoto, H., Gurpide. (1989) Proliferation and responsiveness to estrogen of human endometrial cancer cells under serum-free culture conditions. Cancer Res. Jun 15;49(12):3297-301. 
Holinka, C.F., Hata, H., Kuramoto, H., Gurpide, E. (1996) Responses to estradiol in a human endometrial adenocarcinoma cell line (Ishikawa). J Steroid Biochem. Jan;24(1):85-9.

Holme, J.A., Hongslo, J.K., Bjornstad, C., Harvison, P.J., Nelson, S.D. (1988) Toxic effects of paracetamol and related structures in V79 Chinese hamster cells. Mutagenesis. Jan;3(1):51-6.

Honglso, J.K., Brogger, A., Bjorge, C., Holme, J.A. (1991) Increased frequency of sisterchromatid exchange and chromatid breaks in lymphocytes after treatment of human volunteers with therapeutic doses of paracetamol. Mutat Res. Sep;261(1):1-8.

Hongslo JK, Smith CV, Brunborg G, Soderlund EJ, Holme JA (1994) Genotoxicity of paracetamol in mice and rats. Mutagenesis. Mar;9(2):93-100.

Hoyer, A.P., Grandjean, P., Jorgensen, T., Brock, J.W., Hartvig, H.B. (1998) Organochlorine exposure and risk of breast cancer. Lancet 352(9143):1816-20.

Isenhower, W.D. Jr., Newbold, R.R., Cefalo, R.C., Korach, K.S., McLachlan, J.A. (1986) Absence of estrogenic activity in some drugs commonly used during pregnancy. Biol Res Pregnancy Perinatol. 7(1):6-10.

Jacobson $_{\mathrm{a}}$, J.L and Jacobson, S.W. (1989) Effects of Exposure to PCBs and related compounds on growth and activity in children. Neurotoxicol. and Teterol. 12:319-326.

Jacobson $_{\mathrm{b}}$, J.L and Jacobson, S.W. (1993) A 4-year followup study of children born to consumers of Lake Michigan fish. Internat. Assoc. Great Lakes Res. 19(4):776-83.

Jennings, M.L., Percival, H.F., Woodward, A.R. (1988) Evaluation of alligator hatchling and egg removal from three Florida lakes. Proc. Ann. Conf. Southeast Assoc. Fish Wildl. Agencies 42:283-94.

Jollow $_{\mathrm{a}}$, D.J., Mitchell, J.R., Potter, W.Z., Davis, D.C., Gillette, J.R., Brodie, B.B. (1973) Acetaminophen-induced hepatic necrosis. II. Role of covalent binding in vivo. $J$ Pharmacol Exp Ther. Oct;187(1):195-202.

Jollow, , D.J., Thorgeirsson, S.S., Potter, W.Z., Hashimoto, M., Mitchell, J.R. (1974) Acetaminophen-induced hepatic necrosis. VI. Metabolic disposition of toxic and nontoxic doses of acetaminophen. Pharmacology;12(4-5):251-71.

Kappers, W.A., van Och, F.M., de Groene, E.M., Horbach, G.J. (2000) Comparison of three different in vitro mutation assays used for the investigation of cytochrome P450-mediated mutagenicity of nitro-polycyclic aromatic hydrocarbons. Mutat Res. Mar 23;466(2):143159. 
Kassan, S., Mechanick, J.I., Gurpide, E. (1989) Altered estrogen receptor system in estrogenunresponsive human endometrial adenocarcinoma cells. J Steroid Biochem. Sep;33(3):327-33.

Khan, S.A., Ball, R.B., Hendry W.J. $3^{\text {rd }}$ (1998) Effects of neonatal administration of diethylstilbestrol in male hamsters: disruption of reproductive function in adults after apparently normal pubertal development. Biol Reprod. 58(1): 37-42.

Kharat, I. and Saatcioglu, F. (1996) Antiestrogenic effects of 2,3,7,8-tetrachlorodibenzo-p-dioxin are mediated by direct transcriptional interference with the liganded estrogen receptor. Cross-talk between aryl hydrocarbon- and estrogen-mediated signaling. J. Biol. Chem. May 3;271(18):10533-7.

Klinge, C.M., Bowers, J.L., Kulakosky, P.C., Kamboj, K.K., Swanson, H.I. (1999) The aryl hydrocarbon receptor (AHR)/AHR nuclear translocator (ARNT) heterodimer interacts with naturally occurring estrogen response elements. Mol. Cell Endocrinol. Nov 25;157(1-2):105-19.

Klinge, C.M., Kaur, K., Swanson, H.I. (2000) The aryl hydrocarbon receptor interacts with estrogen receptor alpha and orphan receptors COUP-TFI and ERRalpha1. Arch. Biochem. Biophys. Jan 1;373(1):163-74.

Krieger, N., Wolff, M.S., Hiatt, R.A., Rivera, M., Vogelman, J., Orentreich, N. (1994) Breast cancer and serum organochlorines: A prospective study among white, black and asian women. J. Natl. Cancer Inst. 86(8):589-99.

Lerda, D. and Rizzi, R. (1991) Study of reproductive function in persons occupationally exposed to 2,4- dichlorophenoxyacetic acid (2,4-D). Muta. Res. 262(1):47-50.

Littlefield, B.A., Gurpide, E., Markiewicz, L., McKinley, B., Hochberg, R.B. (1990) A simple and sensitive microtiter plate estrogen bioassay based on stimulation of alkaline phosphatase in Ishikawa cells: estrogenic action of delta 5 adrenal steroids. Endocrinology. Dec;127(6):2757-62.

Lonkey, E., Reihman, J., Darvill, T., Mather, J. Sr., Daly, H. (1996) Neonatal Behavioral Assessment Scale performance by maternal consumption of environmentally contaminated Lake Ontario fish. J. Great Lakes Res. 22(2):198-212.

Ludwig, J.P., Kurito-Matsuba, H., Auman, H.J., Ludwig, M.E., Summer, C.L., Giesey, J.P., Tillet, D.E., Jones, P.D. (1996) Deformities, PCBs, and TCCD-equivalents in doublecrested cormorants (Phalacrocorax auritus) and caspian terns (Hydroprogne caspia) of the Upper Great Lakes 1986-1991: Testing a cause-effect hypothesis. J. Great Lakes Res. 22(2):172-197. 
Lundholm, C.E. (1991) Influence of chlorinated hydrocarbons, HG2+ and methyl-Hg+ on steroid hormone receptors from eggshell gland mucosa of domestic fowls and ducks. Arch.

Toxicol. 65(3):220-27.

Ma, Q., Dong, L., Whitlock, J.P. Jr., (1998) Transcriptional activation by the mouse Ah receptor. Interplay between multiple stimulatory and inhibitory functions. J. Biol. Chem. May 26;270(21):12697-703.

Mably, T.A., Moore, R.W., Peterson, R.E. (1992) In utero and lactational exposure of male rats to 2,3,7,8-tetrachlorodibenzo-p-dioxin. 1. Effects on adrenergic status. Toxicol. Appl. Pharmacol 114(1):97-107.

Makrigiannakis, A., Margioris, A., Markogiannakis, E., Stournaras, C., Gravanis, A. (1992) Steroid hormones regulate the release of immunoreactive beta-endorphin from the Ishikawa human endometrial cell line. J Clin Endocrinol Metab. Aug;75(2):584-9.

Markogiannakis, E., Georgoulias, V., Margioris, A.N., Zoumakis, E., Stournaras, C., Gravanis. (1997) Estrogens and glucocorticoids induce the expression of c-erbB2/NEU receptor in Ishikawa human endometrial cells. Life Sci.;61(11):1083-95.

Markiewicz, L. and Gurpide, E. (1997) Estrogenic and progestagenic activities of physiologic and synthetic androgens, as measured by in vitro bioassays. Methods Find Exp Clin Pharmacol. May;19(4):215-22.

McKenna, M.J., Hamilton, T.A., Sussman, H.H. (1979) Comparison of human alkaline phosphatase isoenzymes. Structural evidence for three protein classes. Biochem J. Jul $1 ; 181(1): 67-73$.

McLachlan, J.A., Newbold, R.R., Bullock, B.C. (1980) Long-term effects on the female mouse genital tract associated with prenatal exposure to diethylstilbestrol. Cancer Res. 40:398899.

McLachlin, J.A., Newbold, R.R., Teng, C.T., Korach, K.C. (1992) Environmental estrogens: orphan receptors and genetic imprinting. In: Chemically-induced alterations in sexual and functional development: The wildlife/human connection. (Colburn, T. and Clement, C. eds.) Princeton, New Jersey: Princeton Scientific Publishing:107-112.

Milham, S. Jr. (1993) Unusual sex ratio of births to carbon setter fathers. Am J Ind Med. 23(5):829-31.

Miller, M.R., Wentz, E., Ong, S. (1999) Acetaminophen alters estrogenic responses in vitro: inhibition of estrogen-dependent vitellogenin production in trout liver cells. Toxicol Sci. Mar;48(1):30-7. 
Mitchell, J.R., Jollow, D.J., Potter, W.Z., Gillette, J.R., Brodie, B.B. (1973) Acetaminopheninduced hepatic necrosis. IV. Protective role of glutathione. J Pharmacol Exp Ther. Oct;187(1):211-7.

Mulivor, R.A., Boccelli, D., Harris, H. (1985) Quantitative analysis of alkaline phosphatases in serum and amniotic fluid: comparison of biochemical and immunologic assays. $J$ Lab Clin Med. Mar;105(3):342-8.

Murphy, M., Johnston, C., Whelan,P., Rider, L., Lloyd, S.N. (1999) Changing trends in prostatic cancer. BJU Int. May;83(7):786-91.

National Toxicology Program (NTP) (1993). Toxicology and Carcinogenesis Studies of Acetaminophen (CAS No. 103-90-2) in F344/N B6C3F1 Mice Mice (Feed studies). Technical Report Series No. 394. NIH publication No. 93-2849. U.S. Department of Health and Human Services, Public Health Service, National Institutes of Health, Research Triangle Park, NC.

Newbold, R. (1995) Cellular and Molecular Effects of Developmental exposure to diethylstilbestrol: Implications for other environmental estrogens. Environ Health Perspect. 103(7):3-87.

Nishada, M., Kasahara, K., Kaneko, M., Iwasaki, H. (1985) Establishment of a new human endometrial adenocarcinoma cell line, Ishikawa Cells, containing estrogen and progesterone receptors. ACTA Obst. Gynaec. Jpn. vol 37, No. 7, pp.1103-1111.

Paulozzi, L.J., Erickson, J.D., Jackson, R.J. (1997) Hypospadias trends in two US surveillance systems. Pediatrics. Nov;100(5):831-4.

Piperno, E., Berssenbruegge, D.A. (1976) Reversal of experimental paracetamol toxicosis with $\mathrm{N}$-acetylcysteine. Lancet Oct 2;2(7988):738-9.

Prescott, L. (1996) Paracetamol (Acetaminophen). A Critical Biographical Review. Taylor and Francis, Pa..

Rae, T. (1986) The biological response to titanium and titanium-aluminium-vanadium alloy particles. I. Tissue culture studies. Biomaterials 1986 Jan;7(1):30-6.

Rajkhowa, M., Glass, M.R., Rutherford, A.J., Balen, A.H., Sharma, V., Cuckle, H.S. (2000) Trends in the incidence of ectopic pregnancy in England and Wales from 1966 to 1996. BJOG. Mar;107(3):369-74.

Rang, H., Dale, M.M., Ritter, J.M., Gardner, P. (1995) Pharmacology. pp250-51, Churchill Livingstone, New York. 
Ray, S.D., Jena, N. (2000) A hepatotoxic dose of acetaminophen modulates expression of BCL2, BCL-X(L), and BCL-X(S) during apoptotic and necrotic death of mouse liver cells in vivo. Arch Toxicol. Jan;73(10-11):594-606.

Reel, J.R., Lawton, A.D., Lamb, J.C. $4^{\text {th }}$ (1992) Reproductive toxicity evaluation of acetaminophen in Swiss CD-1 mice using a continuous breeding protocol. Fundam Appl Toxicol. Feb;18(2):233-9.

Rodman, L.E., Shedlofsky, S.I., Mannschreck, A., Puttman, M., Swim, A.T. and Robertson, I.W. (1991) Differential potency of atropisomers of polychlorinated biphenyls on cytochrome P450 induction and uroporphyrin accumulation in the chick embryo hepatocyte culture. Biochem Pharmacol. 1:41(6-7):915-22.

Romanoff, A.J. (1960) The avian embryo. New York:Macmillan

Rowlands, C., Krishnan, V., Wang, X., Santostefano, M., Safe,S., Miller, W.R., Langdon, S. (1993) Characterization of the aryl hydrocarbon receptor and aryl hydrocarbon responsiveness in human ovarian carcinoma cell lines. Cancer Res. Apr 15;53(8):1802-7.

Rudd, R.L. and Herman, S.G. (1972) Toxic effect of pesticide residues on wildlife. In: Environmental Toxicology of Pesticides (Matsumura, F., ed.) New York:Academic Press :471-85.

Rustin, G.J., Wilson, P.D., Peters, T.J. (1979) Studies on the subcellular localization of human neutrophil alkaline phosphatase. J Cell Sci. Apr;36:401-12.

Sant, M., Barchielli, A., Francisci, S., Canario, F. (1999) The prevalence of tumors of the breast and female genital tract in Italy. Tumori. Sep-Oct;85(5):382-6.

Santti, R., Makela, S., Strauss, L., Korkman, J., Kostian, M.L. (1998) Phytoestrogens:potential endocrine disruptors in males. Toxicol. Ind. Health 14(1-2):223-37.

Semenza, J.C., Tolbert, P.E., Rubin, C.H., Guillette, L.J. Jr., Jackson, R.J. (1997) Reproductive toxins and alligator abnormalities at Lake Apopka, Florida. Environ Health Perspect. 105(10):1030-2.

Sharpe, R.M., Fisher, J.S., Millar, M.M., Jobling, S., Sumpter, J.P. (1995) Gestational and lactational exposure of rats to xenoestrogens results in reduced testicular size and sperm production. Environ Health Perspect. 103(12):1136-43.

Simard, J., Sanchez, R., Poirier, D., Gauthier, S., Singh, S.M., Merand, Y., Belanger, A., Labrie, C., Labrie, F. (1997) Blockade of the stimulatory effect of estrogens, OH-tamoxifen, OHtoremifene, droloxifene, and raloxifene on alkaline phosphatase activity by the antiestrogen EM-800 in human endometrial adenocarcinoma Ishikawa cells. Cancer Res. Aug 15;57(16):3494-7. 
Soontornchat, S., Li, M.H., Cooke, P.S., Hansen, L.G. (1994) Toxicokenetic and toxicodynamic influences on endocrine disruption by polychlorinated biphenyls. Environ Health Perspect. 102(6-7):568-71.

Spitzer, P.R., Riseborough, R.W., Walker, W. 2d, Hernandez, R., Poole, A., Puleston, D., Nisbet, I.C. (1978) Productivity of ospreys in Conneticut-Long Island increases as DDE residues decline. Science 202:333-35.

Stellman, S.D., Djordjevic, M.V., Muscat, J.E., Gong, L., Bernstein, D., Citron, M.L., White, A., Kemeny, M., Busch, E., Nafziger, A.N. (1998) Relative abundance of organochlorine pesticides and polychlorinated biphenyls in adipose tissue and serum of women in Long Island, New York. Cancer Epidemiol Biomarkers Prev 7(6):489-96.

Swan, S.H., Elkin, E.P. (1999) Declining semen quality: can the past inform the present? Bioessays. Jul;21(7):614-21.

Tonge, R.P., Kelly, E.J., Bruschi, S.A., Kalhorn, T., Eaton, D.L., Nebert, D.W., Nelson, S.D. (1998) Role of CYP1A2 in the hepatotoxicity of acetaminophen: investigations using Cyp1a2 null mice. Toxicol Appl Pharmacol. Nov;153(1):102-8.

Toppari, J., Larsen, J.C., Christiansen, P., Giwercman, A., Grandjean, P., Guillette, L.J. Jr., Jegou, B., Jensen, T.K., Jouannet, P., Keiding, N., Leffers, H., McLacklan, J.A., Meyer, O., Muller, J., Rajpert-De Meyts, E., Scheike, T., Sharpe, R., Sumpter, J., Skakkebaek, N.E. (1996) Male reproductive health and environmental xenoestrogens. Environ Health Perspect. 104(4):41-803.

Toran-Allerand, C.D., Singh, M., Set, G. Jr. (1999) Novel mechanisms of estrogen action in the brain: new players in an old story. Front Neuroendocrinol 20(2):97-121.

Udenfriend, S., Stein, S., Bohlen, P., Dairman, W., Leimgruber, W., Weigele, M. (1972) Fluorescamine: a reagent for assay of amino acids, peptides, proteins, and primary amines in the picomole range. Science. Nov 24;178(63):871-2.

vom Saal, F.S., Cooke, P.S., Buchanan, D.L. Palanza, P. Thayer, K.A., Nagel, S.C., Parmigiani, S., Welshons, W.V. (1998) A physiologically based approach to the study of bisphenol A and other estrogenic chemicals on the size of reproductive organs, daily sperm production, and behavior. Toxicol Ind Health. 14(1-2):239-60.

Vonier, P.M., Crain, D.A., McLachlan, J.A., Guillette, L.J. Jr., Arnold, S.F. (1996) Interaction of environmental chemicals with the estrogen and progesterone receptors from the oviduct of the American alligator. Environ Health Perspect. 104(12):1318-22.

Vonier, P.M., Guillette, L.J. Jr., McLachlan, J.A., Arnold, S.F. (1997) Identification and characterization of estrogen and progesterone receptors from the oviduct of the American alligator (Alligator mississippiensis). Biochem Biophys Res Commun. 17;232(2):308-12. 
Welch, S. and Martin B.R. (1997) Modern Pharmacology with Clinical Applications, $5^{\text {th }}$ Ed. (Craig, C.R. and Stitzel, R.E. eds) pp327-328, Little, Brown and Company, New York.

Weidner, I.S., Moller, H., Jensen, T.K., Skakkebaek, N.E. (1998) Cryptorchidism and hypospadias in sons of gardeners and farmers. Environ Health Perspect. Dec;106(12):793-6.

Wiger, R., Hongslo, J.K., Evenson, D.P., De Angelis, P., Schwarze, P.E., Holme, J.A. (1995) Effects of acetaminophen and hydroxyurea on spermatogenesis and sperm chromatin structure in laboratory mice. Reprod Toxicol. Jan-Feb;9(1):21-33.

Wiger, R., Finstad, H.S., Hongslo, J.K., Haug, K., Holme, J.A. (1997) Paracetamol inhibits cell cycling and induces apoptosis in HL-60 cells Pharmacol Toxicol. Dec;81(6):285-93.

Willingham, E. and Crews, D. (1999) Sex reversal effects of environmentally relevant xenobiotic concentrations on the red-eared slider turtle, a species with temperature-dependent sex determination. Gen Comp Endocrinol. 113(3):429-35.

Wingo, P.A., Ries, L.A., Rosenberg, H.M., Miller, D,S., Edwards, B.K. (1998) Cancer incidence and mortality, 1973-1995: a report card for the U.S. Cancer. Mar 15;82(6):1197-207.

Wolff, M.S., Toniolo, P.G., Lee, E.W., Rivera, M., Dubin, N. (1993) Blood levels of organochlorine residues and risk of breast cancer. J. Natl. Cancer Inst. 21;85(8):648-52.

Woodward, A.R., and Moore, C.T. (1989) Statewide alligator surveys. Final Report. Tallahasse, FL:FL Game Freshwater Fish Commision :1-24.

Wormke, M., Castro-Rivera, E., Chen, I., Safe, S. (2000) Estrogen and aryl hydrocarbon receptor expression and crosstalk in human Ishikawa endometrial cancer cells. J Steroid Biochem. Mol. Biol. Apr;72(5):197-207. 